
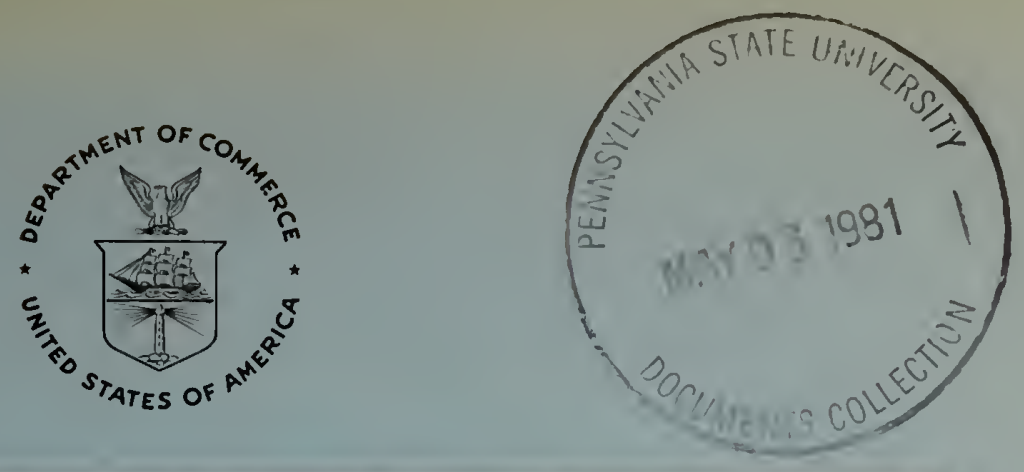

\title{
A Balanced Marine Aquarium
}

\section{The Biology of Marine Aquarium Fishes Collected in Marine County, Florida}

\section{U.S. Department of Commerce}

National Oceanic and Atmospheric Administration

National Marine Fisheries Service 
The NOAA Technical Memorandum NMFS series is used for informal scientific and technical publications, specialized reports that require multiple copies when complete formal review and editorial processing are not appropriate or feasible. Requests for copies of this Technical Memorandum should be sent to the Southeast Fisheries Center, National Marine Fisheries Service, Miami Laboratory, 75 Virginia Beach Drive, Miami, FL 33149.

The National Marine Fisheries Service (NMFS) does not approve, recommend or endorse any proprietary product or proprietary material mentioned in this publication. No reference shall be made to NMFS, or to this publication furnished by NMFS, in any advertising or sales promotion which would indicate or imply that NMFS approves, recommends or endorses any proprietary product or proprietary material mentioned herein, or which has as its purpose an intent to cause directly or indirectly the advertised product to be used or purchased because of this NMFS publication. 


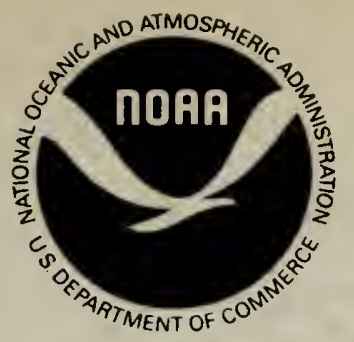

\section{A Balanced Marine Aquarium (page 1)}

Barbara Jayne Palko Southeast Fisheries Center NMFS Miami Laboratory

\section{The Biology of Marine Aquarium Fishes Collected in Marine County, Florida (page 26)}

Deb Hess and John Stevely

Monroe County Marine Advisory Program

Florida Cooperative Extension Service

A two-paper

NOAA Technical

Memorandum,

NMFS-SEFC-59

January 1981 


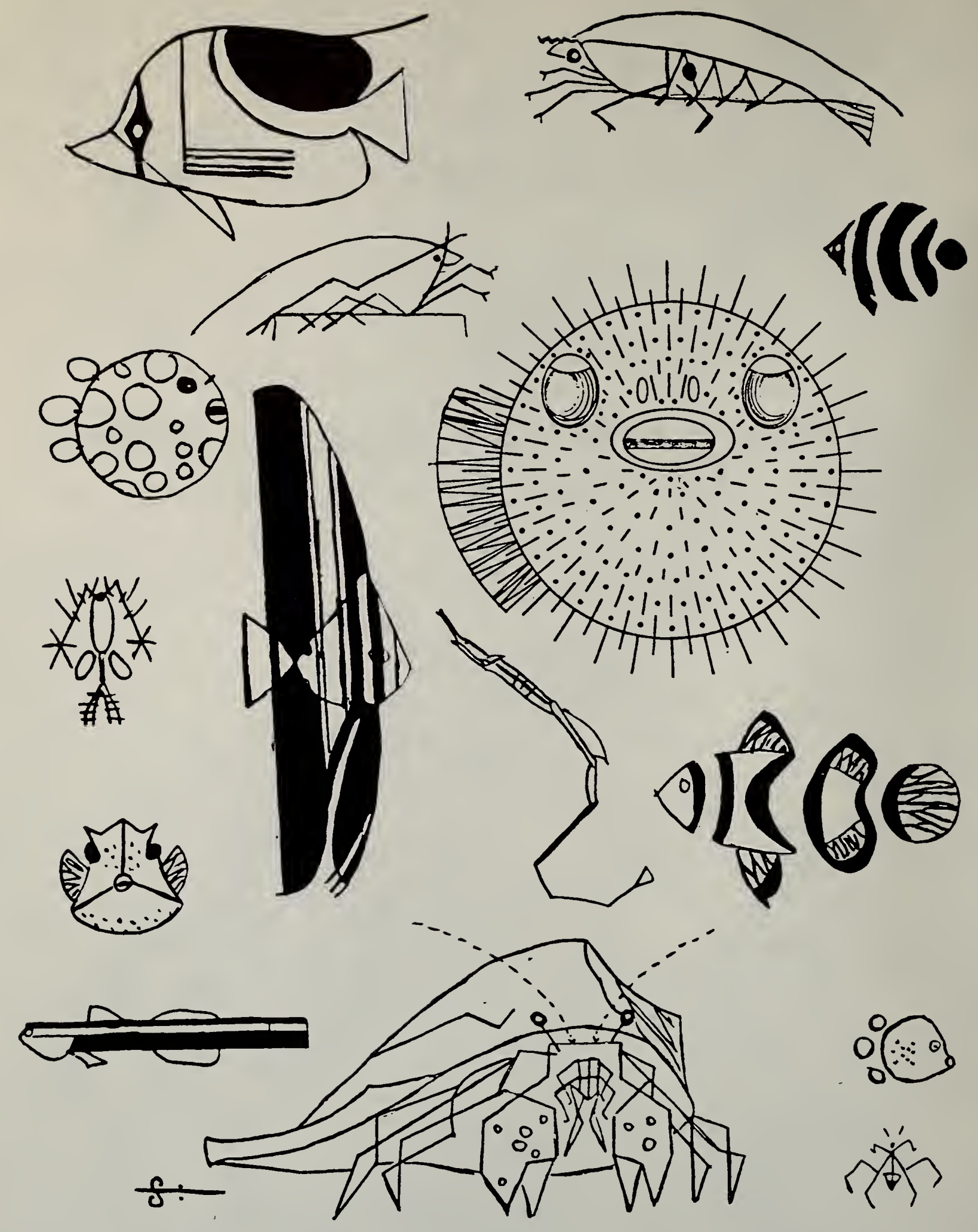


A BALANCED MARINE AQUARIUM

by

Barbara Jayne Palko

Fishery Biologist

\section{Southeast Fisheries Center National Marine Fisheries Service Miami Laboratory \\ 75 Virginia Beach Drive Miami, Florida 33149 305-361-4251}

Artwork by Craig Phillips Director, National Aquarium U.S. Fish and Wildlife Service Washington, D.C. 
Digitized by the Internet Archive in 2012 with funding from LYRASIS Members and Sloan Foundation 
A balanced marine aquarium reproduces the natural environment as closely as possible. Before the introduction of the balanced aquarium, marine fishes were usually kept in systems separate from marine invertebrates. The balanced marine aquarium, however, permits the successful mixing of fish and invertebrates within the closed system and has become increasingly popular in the past few years. It is more appealing and the behavior of the fishes and invertebrates within the system is more natural.

A marine aquarium that is set up and maintained for periods of six months or longer without medication, chemical additions, or other treatments is the mark of a successful marine aquarist. All you add are food and water. The bottom medium may contain crushed coral, beach shell, or calcified algae (not silica sand or colored gravel). The habitat of the aquarium is made up of rock with living organisms on it, cured coral, plants, and anemones (not plastic figures or ceramics). You should not suffer severe losses from disease, and fishes should only need to be removed when they have become too large for the system. Everything within the system is compatible in its mini-habitat within your home. Does this sound impossible? Well, it isn't.

In setting up a balanced marine aquarium, an important factor is PATIENCE. A well-balanced saltwater aquarium cannot be established in one day, but with patience, you will be rewarded by an aquarium that is both beautiful and trouble-free. No single set of rules will guarantee the successful setup and operation of a saltwater aquarium, for there is more 
than one way to achieve a well-balanced marine aquarium. Books and pamphlets are only aids. This pamphlet will show you one way. Success depends on you and the amount of time you are willing to give to your aquarium. If you do not want to be totally involved, then set up a large tank with hardy fish that can survive without a great deal of care. However, if you are willing to accept the challenge of some of the more delicate and rarer tropicals, then you must be willing to give more of yourself.

Equipment - Basic and Optional

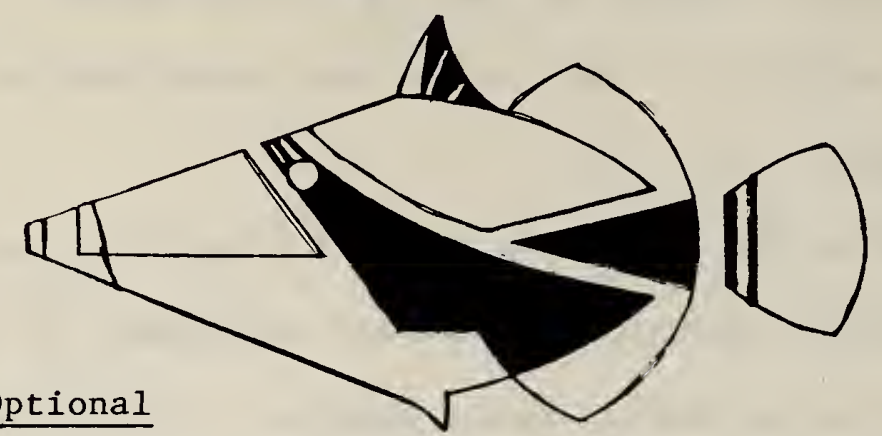

A saltwater aquarium should be all glass or plastic, no smaller than 20 gallons for the beginner. Remember, larger aquariums are generally easier to take care of, but harder to set up initially. You must have a sturdy stand or base that will support the aquarium, water, and habitat weight. For a 30 gallon aquarium, the weight will be a minimum of 250 pounds. You should also cut a $1 / 2$ " thick piece of styrofoam the same size as your aquarium base to be used as a cushion. Additional basic equipment required are an air pump, check valve, gang valve, air line tubing, saltwater undergravel filter, glass cover, and fluorescent light.

Optional equipment includes an outside power filter with dacron floss and activated carbon or an ion-exchange resin, heater, an undergravel power pump, and/or an ultraviolet purifier (preferably with the bulbs above the water for easier maintenance and better efficiency). 
Combination glass, metal, and slate aquariums are still safe for freshwater fish but should not be used for a marine aquarium, as seawater reacts with the metal and slate causing rust and toxins that can kill marine fish and invertebrates. The check valve is used to prevent backsyphoning in the event of a power failure. The undergravel filter is used to support the bottom media above a water column to assure good water circulation thus enabling nitrifying bacteria to carry out their biological role of breaking down waste and organic matter. Purchase an undergravel filter designed for saltwater. The stems are larger and the platform base higher than freshwater filters.

The undergravel power filter is a fairly new product and some data indicate it improves the efficiency of the undergravel filter and sets up a current in the aquarium. The outside power filter removes larger particulate matter in suspension in the water. It is also used to pump the water through the ultraviolet filter. This filter helps to break down organics, as well as serving its two primary functions: control of disease caused by microorganisms and maintenance of good water quality. I believe the potential of the ultraviolet purifier has not yet been fully realized. I feel my system lets me do more with a saltwater aquarium than just regular filtration. It lets me put in more fish in one tank than published formulas recommend. You cannot "overdose" a tank with ultraviolet. All research data have shown that it does not change the water chemistry.

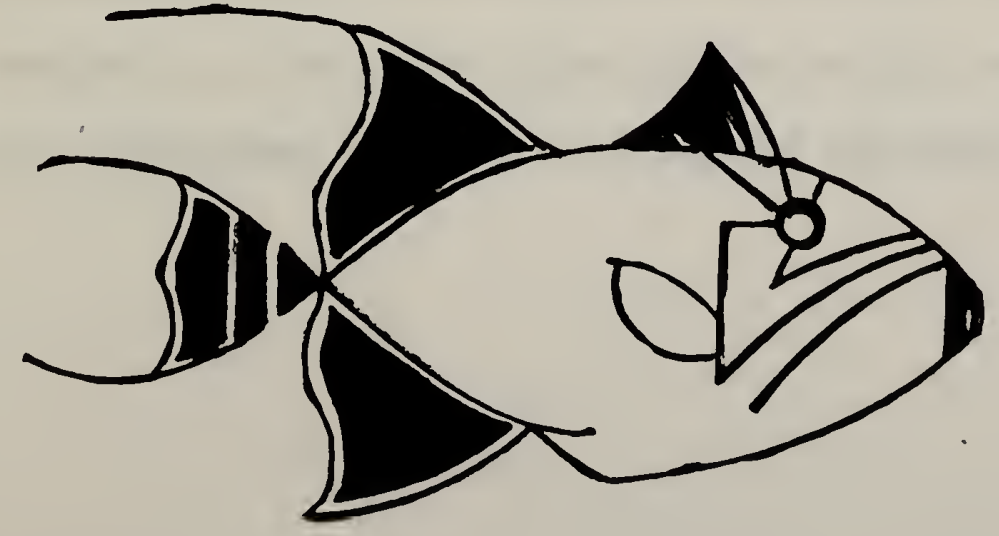


Parental supervision should be considered with younger hobbyists because the combination of salt water and electricity can lead to some shocking experiences!

One of the first steps in setting up any new marine aquarium is to collect reliable seawater. If you live near the ocean, you can collect natural seawater. When you collect seawater from a shoreline or off a bridge (as opposed to collecting offshore by boat), collect at high tide and be sure to filter and age the water before using.

Filter the water by running it through dacron floss and/or coffee filter paper, or a comparable finely meshed material. Age the water in the dark in a covered container for two weeks without aeration. Aging helps to kill many of the algae and microorganisms present in natural seawater.

You can also make seawater by using one of the many brands of artificial sea salts on the market. When mixing artificial salts, use a 5 gallon bucket of warm tap water to help dissolve the salts more readily. Pour the dissolved salts into your empty aquarium and add the rest of your tap water to bring the level within 4 inches of the top of the aquarium.

The use of natural or artificial seawater is an area of debate with aquarists. Artificial seawater is easier to mix than natural seawater is to collect, and it is no longer as expensive as it used to be. Also, reliable brands of sea salts eliminate most of the unknowns, especially disease organisms and parasites, which are present in natural seawater. In addition, it does not have to be filtered or aged before use. 
The bottom medium for saltwater should be some type of carbonate that prevents a dangerously low $\mathrm{pH}$ by maintaining the water in close association with calcium carbonate. Low $\mathrm{pH}$ (an acidic condition) is caused by oxidation, carbon dioxide production by the fish and other marine animals, and by bacterial action. I prefer crushed shell for aquariums with jawfish (they construct burrows in the shell) and calcified algae and crushed coral (available commercially) for other aquariums. Dolomite can also be used, but is not as desirable a carbonate.

If you collect your bottom media yourself, you will need to purify it. The same is true if you collect your own habitat (conch shells or Florida oolite rocks). Bottom media purchased in pet stores need not be purified, only rinsed before use. The same techniques are used for purification of both bottom media and habitat. You want to kill all organisms on the collected material, so when you add it to your aquarium it is "sterile." All media should be gathered below the low tide line to avoid contamination. The shell can be screened to size at the beach. Use a mesh or net with a size between $1 / 4$ and $1 / 2$ inch. Shell smaller than $1 / 4$ inches is undesirable because it can plug up the undergravel filter leaving pockets barren of the much needed nitrifying bacteria. Eliminate shells over 1 inch, except for accents. Remember, when using large shells for accent, such as conchs or helmets, be sure they are cut to allow a good flow of water through them. If the water does not circulate completely through these shells, gases can build up and be released into the aquarium and cause mortalities. With a bottom media of crushed coral and calcified algae, the size should be smaller. According to Dick Greenfield 
$(1978)^{1}$ a 3-inch bed of 1/3-inch diameter bottom media will provide twice the total surface for bacterial attachment than would the same depth of 1/4-inch gravel in the same aquarium. To purify the bottom media, using a 2-gallon plastic bucket (never use metal when working with materials for any saltwater aquarium), add about six handfuls of crushed shell to the bucket, flush with fresh water and agitate until the water flows clear. After rinsing each batch, recombine the shell in a plastic 5-gallon bucket for further purification with bleach. (For those of you who have trouble finding 5-gallon plastic buckets, try your local bakery, donut shop, or fast-food restaurant. They bring pie and donut fillings, pickles, etc., in these buckets and usually discard them when empty.)

Fill the 5-gallon bucket $3 / 4$ full of shell and cover with fresh water to which two cups of bleach have been added. Two days later remove the water and flush the shell again in the smaller plastic bucket and spread the shell in a thin layer on a sheet of plastic to dry. Let dry for 4 to 6 days. Your nose becomes your best test mechanism to see if the shell is clean. Take random handfuls and smell. There should be no hint of chlorine or "fishyness." When the shell smells clean, store it in plastic bags until needed. When you put the shell into the aquarium, it should be wet again with a quick freshwater rinse to eliminate any "clouding" of the water. (Adding the wet shell eliminates any problems of "floaters" with the smaller and lighter weight shells that sometimes do not settle to the bottom of the tank when they are dry.)

1Freshwater and Marine Aquarium Magazine, November 1978: p. 12-14, 90-92, 94, and December 1978: p. 12-14, 88-92. 
When cleaning rock, follow the same procedure. Be sure to soak the rock overnight in freshwater to kill worms and other invertebrate that use the rock as habitat. The next day, remove all worms and other invertebrates with tweezers. Let the rock air dry. Before any rock can be placed in a marine tank, every piece of barnacle, sponge, algae, sand coral, and other organic matter must be removed. Use an ice pick to chip away any remaining organisms. After cleaning thoroughly, bleach the rock as you did the shell, using the same proportions of water and bleach. Dry and test by smelling. If you have missed any of the organic matter, it should appear darker than the natural color of the rock. Reclean and bleach, if necessary.

When choosing habitat rocks, remember to collect only those that are free of iron and other metal contaminates, and those that provide different-sized holes for hiding. In Florida, oolite rock is fine. If you cannot or do not care to collect rocks, you will find a good array of safe decorative rocks in any pet or aquarium shop. Corals are protected by both state and federal laws and must be purchased, not collected in the United States. Check with local or state officials before collecting. Some areas are protected for everyone's future enjoyment.

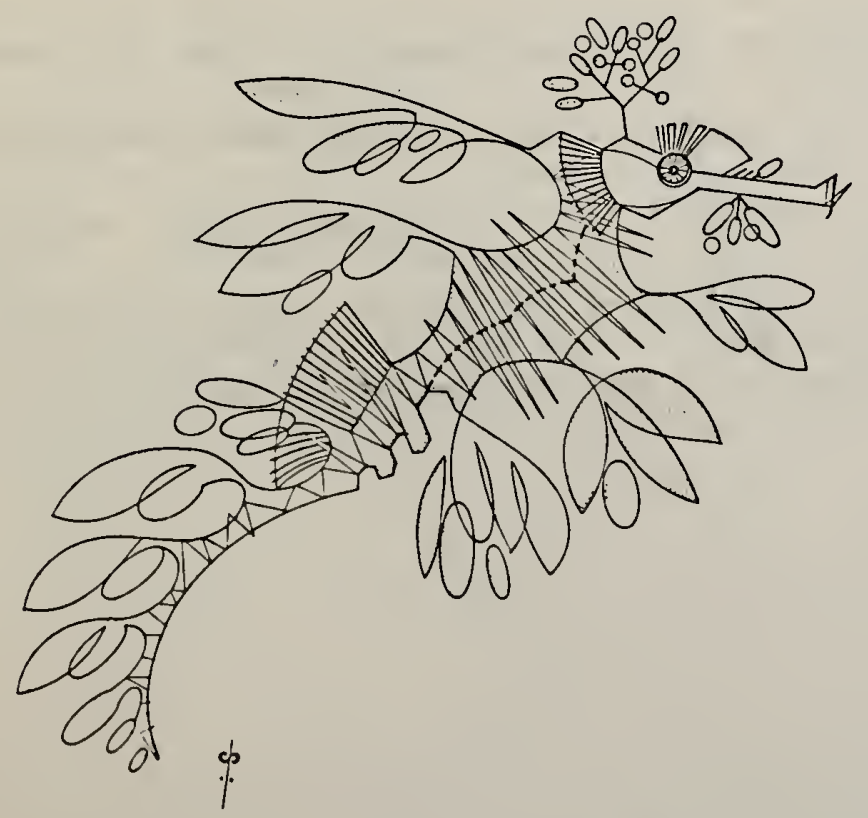


Before adding water, you must be certain your tank is well supported, i.e., placed on a sturdy, strong base. (Remember for a 30-gallon aquarium, your base must support a minimum weight of 250 pounds.) Check the corners to see if the tank is level on all sides. The 1/2-inch thick styrofoam board is placed between the aquarium and the base of the stand to cushion the aquarium and prevent breakage from uneven stress. DO NOT rely on the styrofoam to compensate for a warped base.

With the aquarium stabilized, add your seawater. If you are using artificial sea salts, make sure your salts are all dissolved. Do not add

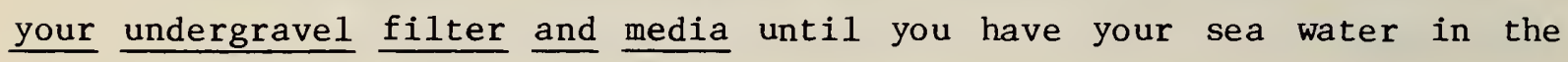
tank. Fill the tank $3 / 4 \mathrm{full}$, then add the undergravel filter plates (with the air line tubing measured and attached). Agitate all bubbles from beneath the filter plates. Gently sprinkle the bottom media (shell or crushed coral) over the top of the plates. Work carefully to prevent smaller pieces from being forced into the slits of the platform. The bottom media should lie on the surface without plugging the holes which will inhibit the operation of the bottom filter, destroying the circulation of water through the filtering media and causing pockets of hydrogen sulfide.

Next add the habitat. Consider the requirements of the fish and invertebrates you will place in the tank. Will the fish have sufficient cover to help prevent aggressive behavior? Try to arrange rocks, corals, and such so the setting appears as natural as possible. With the habitat completed, attach all remaining parts of the mechanical filtering equip- 
ment. Air lines should be attached to the gang valve and that in turn to a check valve on the air pump (to prevent back syphoning). The water level can be topped off by gently pouring the remainder of the seawater into the tank. Use a plate or your hand to lessen the force of the water on the bottom media. Next, connect your ultraviolet filter to the power pump, start the syphons on the power filter, and cover the tank. Lastly, plug in the lights (fluorescent lights are recommended as they are cooler and come in wavelengths that support plant growth). The system is operational, but not ready for fish. The aquarium needs time to balance its biological filter. At this point, it requires a lot of patience to proceed slowly, but a snail's pace, gives nitrifying bacteria in the bottom media an opportunity to establish themselves at levels capable of handling waste from the fish you will add.

There are bacteria in natural seawater and with time these will multiply (but remember bacteria are slow growing). Whether using natural or artifical water, there are ways to introduce the needed bacteria: by adding gravel from an established aquarium into the new one, by using one of the commercial starters, (if you use a commercial starter, proceed with caution - not all starters are alike), or by adding one hardy fish to the tank. DO NOT add a freshwater fish and hope that it dies, rots, and establishes a bacterial colony. The procedure doesn't work and instead is a good way to foul a system, introducing disease. Instead try a damsel fish. They are excellent starters, will feed on anything, are inexpensive, and are very hardy. The natural wastes from the damsel will add nutrients which in turn help to "feed" the bacteria. (I prefer to add one 
portion of dry food - just a pinch - to my new system a week before I introduce my damsel fish. I let it fall to the bottom where it acts as "fertilizer" for bacteria in the grave1.) To establish a balanced tank with artificial seawater takes longer. Most experts recommend a threeweek cycling period as nitrifying bacteria multiply slowly, and lower temperatures, acid water (low $\mathrm{pH}$ ), high salinities, and lack of calcium slow the process more.

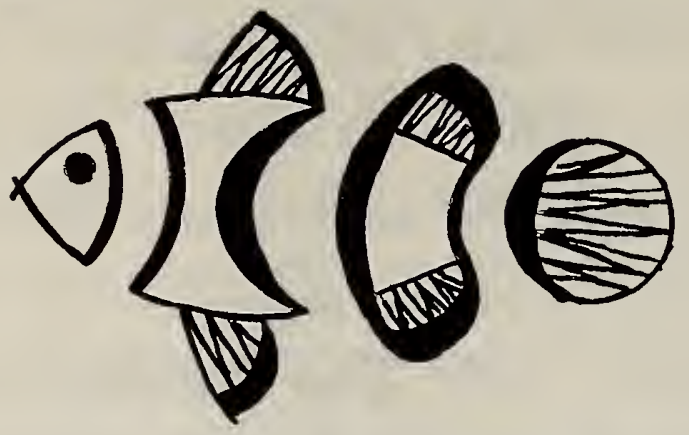

I hope you are a proponent of green algae (as I am). I must emphasize how important algae is as a food supplement for some fish and as a water conditioner for all fish. Here are some passages from Frank de Graaf's book Marine Aquarium Guide (1973) about the importance of algae:

"The saltwater aquarium (unlike the freshwater aquarium) can never sustain sufficient growth of algae to absorb all the substances produced by bacteria. As a result, the aquarium water will gradually accumulate far greater concentrations of all sorts of substances than seawater does . . While the presence of algae can slow down this process, it cannot altogether eliminate it unless the hobbyist is satisfied to keep just 1 or 2 fishes swimming among luxuriant growths of algae - . Nitrates, phosphates, sulfates and even ammonia-- many algae species absorb the latter in preference to nitrates--together with other substances, are indispensable nutrients for algae; promoting an optimal growth of green algae will thus help remove many such substances accumulating in the tank . . The presence of green algae, on the other hand, is an indication that everything is shipshape, since their growth is impeded by an excess of aromatic amino acids and phenols as well as a low redox potential . . In addition to absorbing organic substances and thus keeping the tank water healthy over a longer period of time, algae play yet another role. By giving off certain substances (extra-cellular products), algae considerably influence and improve the general condition of fishes and invertebrates - . It is a fact that in tanks that contain luxuriant algae growths or have an algae filter, fishes hardly ever get sick and show a better growth rate. . Algae are virtually indispensable in the marine aquarium." 
The algae should be introduced during the 2nd and 3rd week. Leave the tank lights burning continuously until the introduction of fish to encourage algal growth. A good supply of algae before the fish are added will encourage its continued growth after the fish begin feeding upon it. There are several ways that you can promote algal growth. I prefer to take some scrapings from the glass of an established tank, and spread the pieces on rocks in the new setup. You can also borrow a piece of "green" coral or rock from a friend's tank and with a toothbrush, spread particles of algae around your aquarium. There are several commercial products that can also be used. Once the fish have been introduced, their waste will provide ample fertilizer for continued growth. Remember, red and brown algae will dominate over green. To prevent this, I suggest that you treat all water with ultraviolet before adding a pure culture of green algae. In addition to the single celled algaes there are other algaes available commercially such as the shaving brush (Penicillus sp.), chain linked (Halimeda $\mathrm{sp}_{\bullet}$ ) and feather plants (Caulerpa $\mathrm{sp}_{\bullet}$ ) which can be purchased from your local pet store and planted.
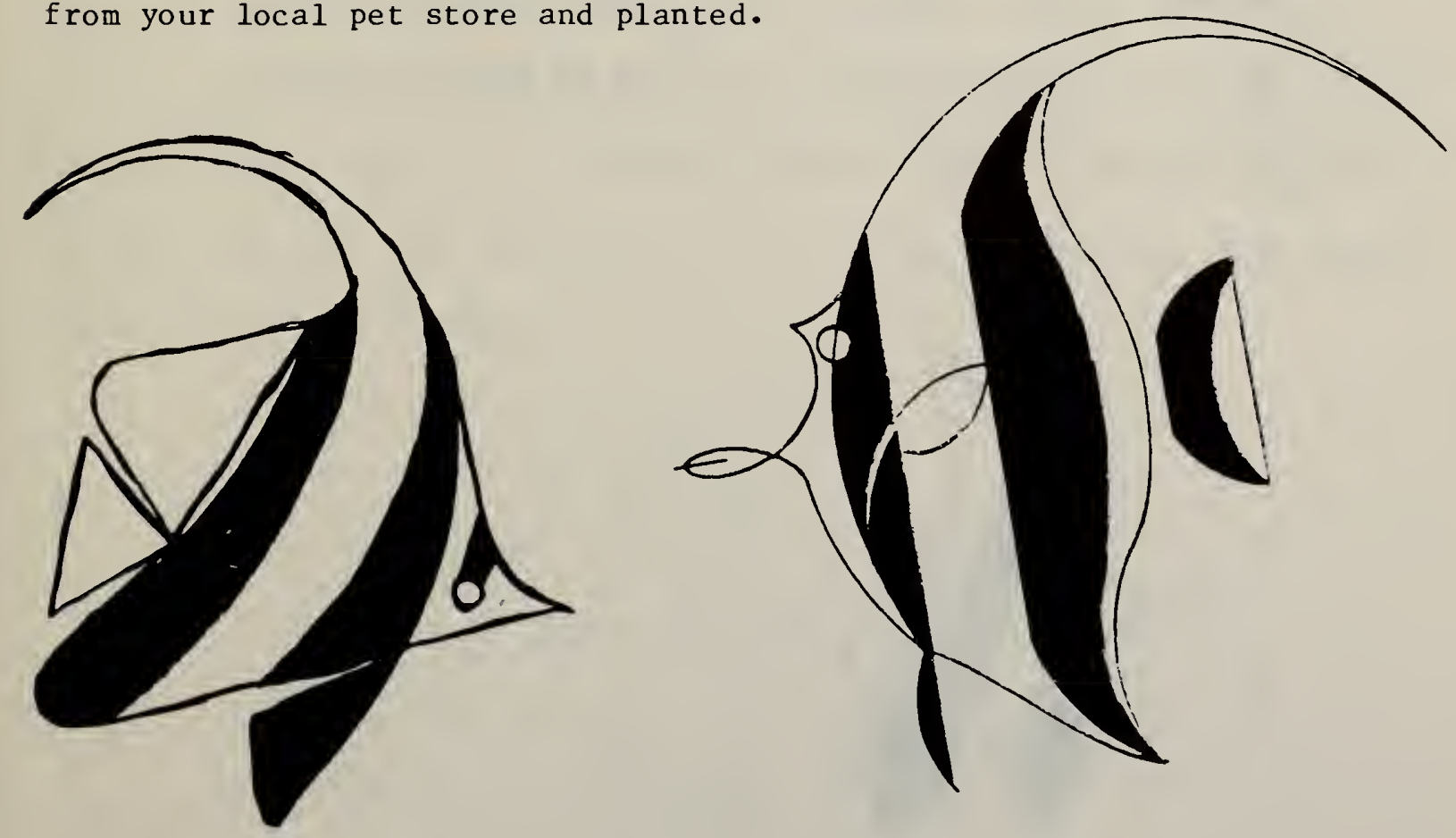
When the two or three weeks cycling period is over, and the bacteria is ready for fish and invertebrates wastes, then it is time to choose a community of fishes for the tank. The following questions are often asked. How many fish can I add? Which fish are the most compatible? As a very conservative rule, you can add one fish 1 inch or less for every two gallons of water, but with the ultraviolet sterilizer and other sophisticated equipment, and some consideration for habitat requirements of the species you select, you have some latitude. The rule of 1 -inch of $\mathrm{fish} / 2 \mathrm{gal}$. of water is not infallible. The weight and volume of a fish increases between the second and third power of the length. That is, a 4-inch fish creates a biological load in a tank closer to 4 times that of the same fish 2 inches long. In short, you may be able to keep fewer larger fish than size alone would indicate. If you plan to stock a tank to its limits, proceed cautiously. If you try for the maximum number a tank can hold, remember to add one fish at a time after you have reached the conservative limit. The point at which you first get mortalities can be considered the maximum limit. The fish you choose depends upon a number of factors: the size of your aquarium, the type of tank you prefer (fish, invertebrate, or both), the area in which you live.

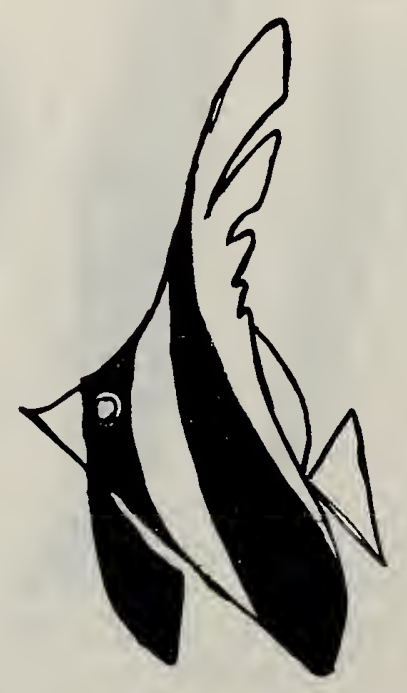


As an illustration, let's assume that you are setting up a 30-gallon tank and from that point of view we'll consider several possibilities, always keeping in mind the habitat requirements and behavior patterns of the fish.

Marine fish occupy all levels of the habitat from open water, coral reef, grass flats, to the bottom substrate. When considering habitats of marine tropicals, generally, jawfish are substrate dwellers, blennies and grammas are rock dwellers, angelfish and butterflyfish are open water fish that "hole up" in the rocks and coral at night, and damselfish occupy whole territories of rock, water, and substrate! Behavior patterns and habitat requirements are generally the same for both Atlantic and Pacific species of the same families. Pacific fish, however, do better at a lower salinity and a lower temperature than Atlantic species. They are also considered by some people to be far more colorful than their Atlantic counterparts. Because some of the marine tropicals such as butterfly fish, rock beauties, and tangs have very specific dietary requirements, I do not recommend their purchase if you cannot provide the proper foods. When you begin choosing fish, make decisions slowly. There are lots of available choices even if this is your first tank and if you proceed slowly, it is hard to fail.

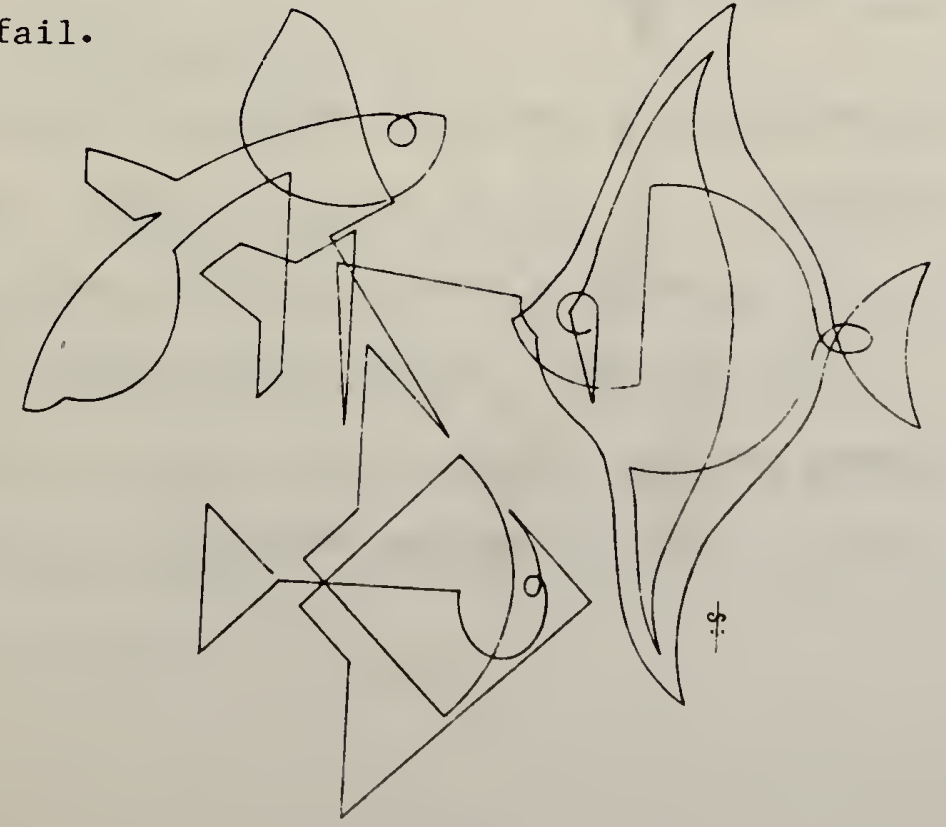


One of the most popular groups of aquarium fish are the angelfish. If you decide to put some angelfish in your tank - and they are an excellent choice for beginners - be sure there is a definite size difference between species. The most docile should be the largest and the most aggressive the smallest. Also, if you are going to have more than one of any species (example 3 pigmy angelfish, Centropygi argi), they should all be added at the same time because certain species are aggressive especial1y towards each other. Keep in mind some of the angelfish are cleaners in their juvenile stages and other species grow to be quite large as adults. Angelfish habitat requirements and behavior patterns are similar. They "hole-up" at night and during the day spend their time in front of the rocks and corals. They like frozen brine shrimp, dried foods and live green algae - basically an easy fish to get to feed. I would not suggest more than 3 angelfish in a 30-gallon community aquarium.

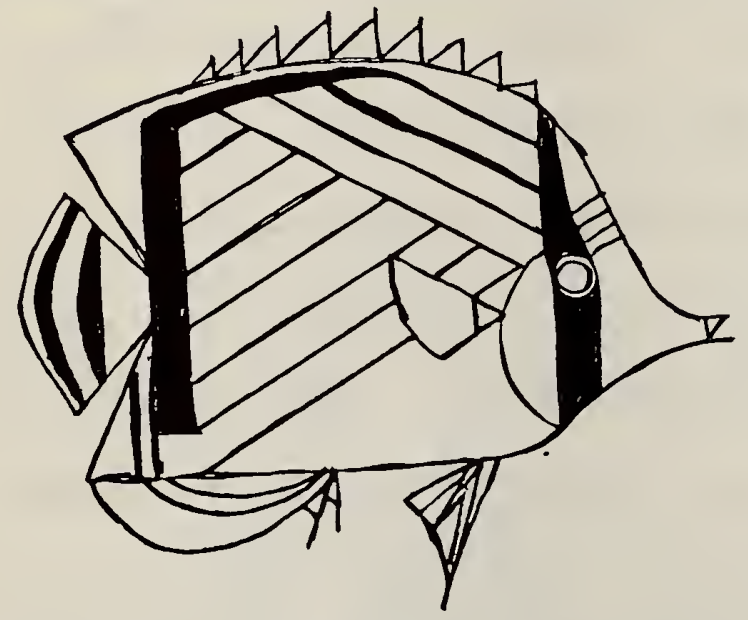

Butterflyfishes are generally less hardy and more difficult to maintain than the angelfishes. Some of the Pacific species must feed on polyps from specific types of coral in order to survive, while others will eat anything you put in the aquarium. Usually butterflyfishes are not as aggressive as angelfishes and thus should be the larger when both are in the same aquarium. Three of the six species available from the Atlantic 
do very well in the home aquariums. They are the Atlantic long nose (Prognathodes aculeatus), the reef (Chaetodon sendentarius), and the

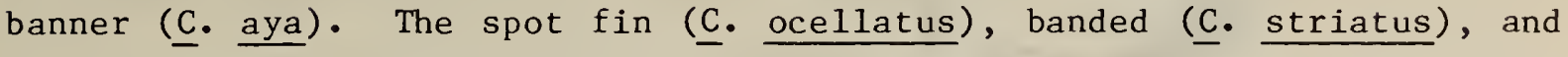
four-eye (‥ capistratus) butterflyfishes are more difficult and sometimes never start feeding well, if at all.

If you have a butterflyfish that is not feeding you might try using an old bleached piece of coral (rose coral works very well), and mash a small piece of raw shrimp into the coral and place that in the tank. Don't put too much shrimp on the coral as it does spoil and can foul the tank. If the butterflyfish starts to feed you can increase the size of the shrimp to match the food requirements of the fish. Another method to stimulate feeding is to add live brine shrimp (Artemis salina) or frozen brine shrimp thawed and soaked in an appetite stimulant. Up to three butterflyfish can be considered for a 30 gallon aquarium.

Other options for middle tank dwellers (besides angelfish and butterfly fish) that should be considered are hogfish, tangs, cardinalfish, squirrelfish, and big eyes. These latter three are reef dwellers that live under rock ledges during the day and come out at night. As a result, they do not do well in brightly lit areas but are good fish in home aquariums where ledges are provided. Tangs are herbivores in their natural habitat. This means they are plant eaters and require algae in large amounts to be happy and to do well. They will eat dry foods and frozen brine but need algae to maintain color and proper diet. Hogfish, wrasses, small sea basses and groupers (Serranids) all are good feeders and are very hardy. Keep in mind, as serranids get bigger, they do develop a taste for smaller fish! One to three of any of the many options from the middle tank dweller will enhance a 30-gallon aquarium, especially since they are so brightly colored. 


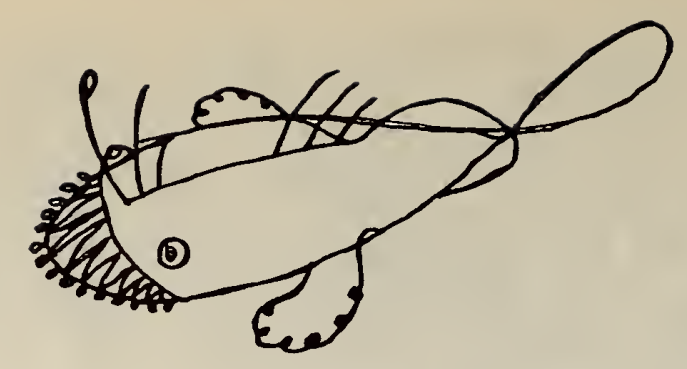

Fish living on the bottom are probably the most popular; good choices would be found among the various species of jawfish and worm gobies. A 30-gallon tank can handle up to six. Jawfish are a good choice, add activity to any tank, have been known to spawn in a community tank, and are all hardy and good feeders. The most important consideration for jawfish is the bottom substrate. Jawfish and worm gobies need shells or coral pieces to structure holes in the bottom of the tank. If you use a "soft" media, such as the finely crushed coral sold commercially, then you must provide them with some decorative clam shells or flat rocks to hide under. If jawfish are unhappy with their "home" they will go to the surface and look for a way out of the tank. They usually succeed, too much to your distress! Bottom dwellers are also notorious for rearranging an aquarium, moving bottom media, she1ls, plants, etc., to suit their desires. If you don't want your aquarium rearranged regularly, do not put jawfish, worm gobies, or other bottom dwellers in your system. Use hermit crabs and brittle starfish instead.

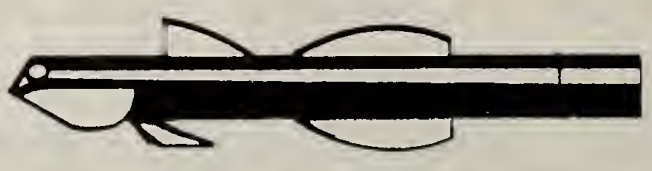

Rock dwellers are also good and possibilities include neon gobies, other gobies, basslets, clinnids, hawkfish, and blennies. The neon goby is a cleaner fish and a pair can be both attractive and functional. They will establish a cleaning station, much as in nature, and have been known to spawn in a closed system. Another choice is the basslets, including the royal grammas (Gramma loreto) and the blackcap basslets (G. melacara). 
These are aggressive fish, especially among their own kind. If you are going to put in more than one gramma or blackcap basslet they must all be introduced at the same time. Once established, the first arrivals will kill any new basslets introduced. Grammas live under ledges in your tank and it is not unusual to see them swimming upside-down. Other rockdweller choices can be made as much on color as on species. Blennies and jawfish are incompatible in the same aquarium and may create some problems, so you may want to consider one of the other rock dweller species if you intend to keep jawfish.

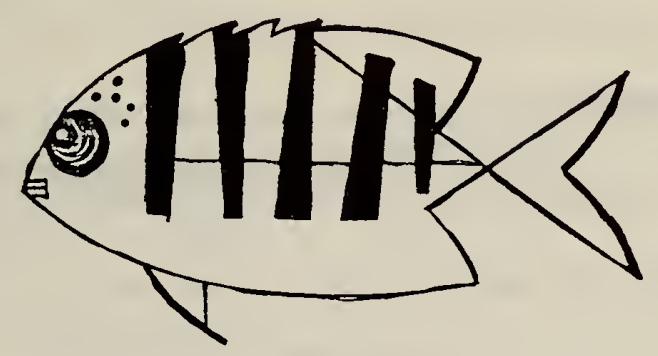

Damsel fish are the one group of fishes that will live, grow, and spawn in nearly anyone's tank. They are very hardy, almost indestructible and do well in any system. If there is a drawback, it is that they are aggressive and extremely territorial. You must remember to leave room for them. If you plan to introduce damsels, remember that each fish requires considerable bottom and rock area as a part of its habitat. Plan for it. Some of the least aggressive damsels are the saffron (Eupomacentrus

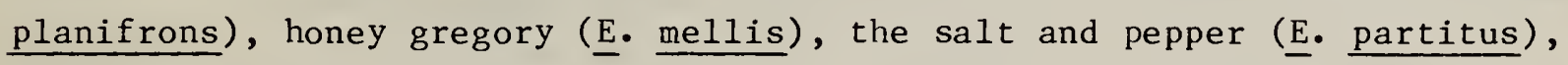
and blue and green reefs (Chromis sp.). If you add damsels, be certain they are the smallest fish in the tank. You needn't worry about their size. Damsels are very competent at taking care of themselves even with fish ten times their size. 


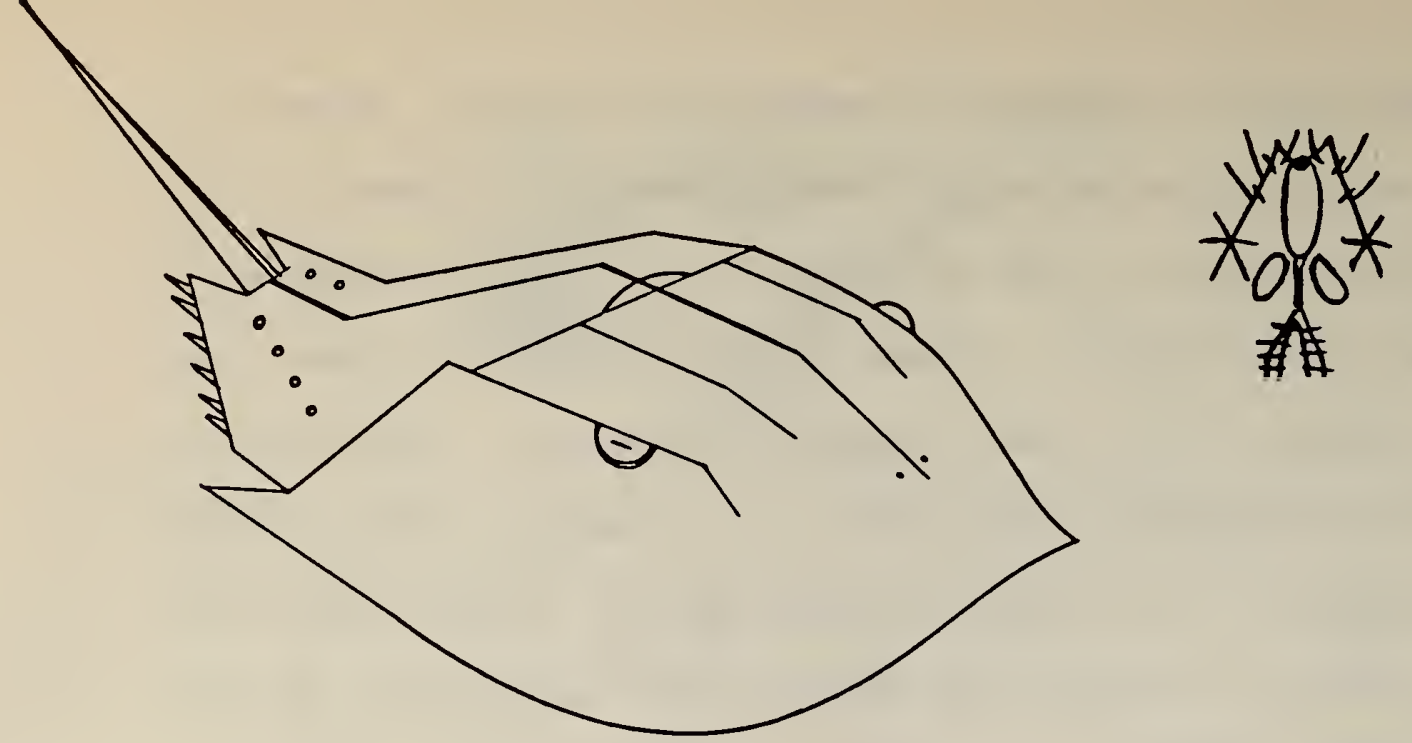

Invertebrates can also be added especially the hardy species. Some choices include banded coral shrimp, sea anemones, brittle and serpent starfish, small hermit crabs (but not arrow crabs since they like to eat fish at night), as well as many of the smaller molluscs and bivalves. Invertebrates make for a more successful aquarium. Anemones aid water quality by their filter feeding activities. Hermit crabs and starfish make good bottom cleaners. They eat the food missed by the fish. Mo1luscs such as flame scallops and spiny oysters are also good water filter feeders while small octopus and live olive or margin shells burrow into the media and keep it clean of large debris. All invertebrates add to the basic balance of a saltwater aquarium as well as making a more interesting tank.

A suggested grouping of fish and invertebrates for a 30-gallon marine aquarium:

\section{Invertebrates}

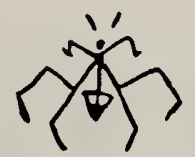

1 pair banded coral shrimp

1 pair pistol shrimp with spiral anemone

1 small hermit crab

1 small starfish or brittle starfish

2 sea anemones

2 flame scallops

1 margin shel1

Marine algae such as Penicillus species Halimeda species and Cauleupa species

Fish

1 pair neon gobies

2 jawfish or worm gobies

1 cardinalfish or hawkfish

1 butterfly

1 hogfish

2 Centropyge species of angelfish

2 basslets 
Do not add all of these fish and invertebrates all at once. When your system is set up and ready, you can add your algae, pistol shrimp and spiral anemone, and starfish as well as your cardinal fish or hawkfish. Ten days later add your hermit crab, margin shell, and sea anemone and two basslets. Ten to fourteen days later, add the remaining invertebrates, neon gobies, butterflyfish and hogfish. Add the centropyge species two weeks later as they are the most aggressive of this selection. Remember, before any fish is placed in your main aquarium, they should be quarantined in a medicine tank first.

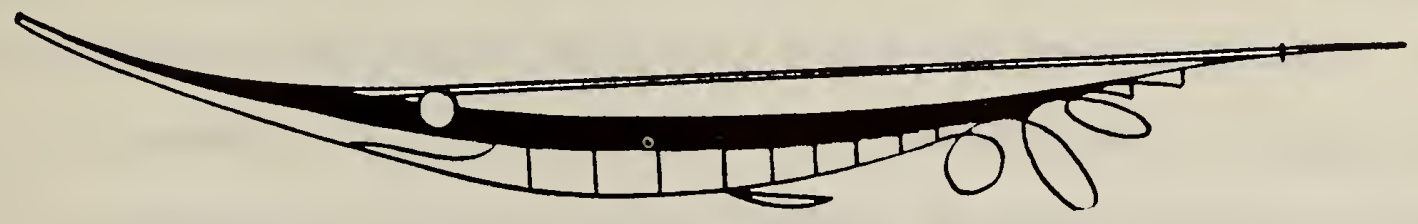

GENERAL MAINTENANCE, FEEDING, AND MEDICATIONS

No one knows precisely the best temperatures for exotic tropical marine fish. Safe ranges are found hit or miss, but there are certain guidelines that work and certain rules that keep problems to a minimum. Both Atlantic and Pacific tropicals will do well in temperatures as low as $70^{\circ}-75^{\circ} \mathrm{F}\left(21^{\circ}-24^{\circ} \mathrm{C}\right)$, and in my own tanks I keep Atlantic tropicals at temperatures between $80^{\circ}-82^{\circ} \mathrm{F}\left(26^{\circ}-27^{\circ} \mathrm{C}\right)$. The most important factor is maintenance of a stable temperature - no matter what range. Daily variations of more than a few degrees should always be avoided. A 5 degree variation can cause stress and encourage disease. Buy a good heater and a reliable thermometer, and keep variation to a minimum year round.

Clean water is essential. Change the volume by $1 / 4$ at least once a month, especially in smaller tanks. The color of the water can be a good indicator of the "health" of the tank. When it begins to yellow and lose its crystal clear look, a water change is overdue. 
If you want to replace the water volume lost through evaporation, remember one fact: the liquid has evaporated, but the salts remain. Therefore, replace the lost volume with distilled or aged tap water. Use your hydrometer to check salinity in the tank. The hydrometer will indicate when the salinity has dropped enough to use seawater instead of tap water. Optimum salinities are $1020-1025$ at $75^{\circ}-80^{\circ} \mathrm{F}$.

Do not overfeed. I feed my fish and invertebrates twice a day, and I believe it is better to feed small amounts more often rather than one large feeding each day. The more you can vary the diet, the healthier the fish will be. I prefer to feed frozen and live brine shrimp (both baby and adult forms) daily, a dry food once or twice a week, and keep marine algae in the tank. Marine algae and plankton (live, frozen, or freezedried) are good food sources. They help to keep the colors of the fish bright. In addition, algae is a necessary part of the diet of tangs and parrotfish. Other foods to consider are chopped beef heart, shrimp, oysters and clams, freeze dried foods such as krill euphausids, tubifex worms, and micro- and macro-plankton (which includes rotifers).

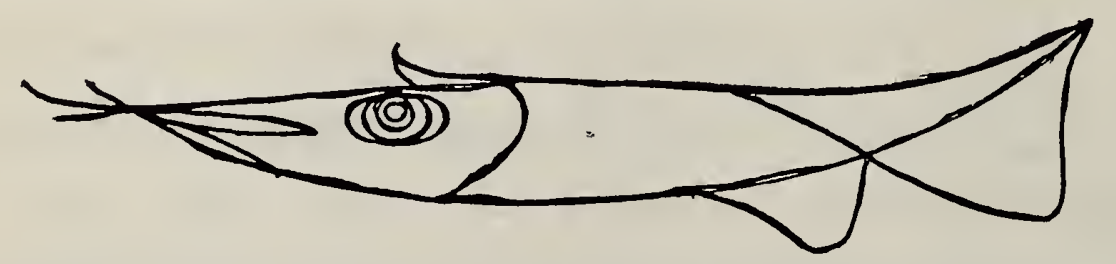

When feeding invertebrates, remember that some are filter feeders and feed only at night. I use live baby brine shrimp which I place in the tank after the lights are off. Clam juice is good for flame scallops and featherduster worms. Liquid fry and finely crushed dryfoods are also 
very good for gorgonians. With the continuing advancements in product research within the marine aquarium industry, many companies are developing foods and diets to maintain many more fish and invertebrates successfully.

One of the most common calls I receive are from people who have little white "bugs" crawling on the glass. The bugs are non-parasitic copepods that occur where there is a high bacterial build-up in an aquarium, often due to fouling of water by overfeeding. Shortly after the copepods appear, the tank may go bad and a fish kill might result (although, fast preventative action can result in no fish loses). This can be corrected by an immediate water change of at least $1 / 2$ the volume. As you change the water, agitate the bottom media to remove the excess food waste.

Another common question I am asked is, "What do I do with diseased fish?" Never medicate in your main tank. If fish are sick, remove them to a "hospital" tank (a 5- or 10-gallon aquarium).

A medicine tank is set up with an undergravel filter, bottom media, and habitat. A copper test kit is also necessary. Using the copper test kit and your copper sulfate solution, stabilize the tank to $0.2 \mathrm{ppm}$ (parts per million). Copper sulfate will combine with the carbonates (your habitat and bottom media); with each temperature and/or $\mathrm{pH}$ change, the copper will go back into solution. However, some of the more recent copper medications (such as Copper Power) stay in solution and do not combine or precipitate out as readily. Copper can also distress or kill invertebrates as their tolerance for copper is even less than fish. All 
fish (collected or purchased) should be held in quarantine for at least one week before they are moved to your main aquarium. While under quarantine, their food should be treated with a broad spectrum antibiotic solution (such as INTRACURE, which is sold as internal medication in pet stores).

To make your own copper sulfate solution, dissolve $10 \mathrm{~g}$ copper sulfate crystals $\left(\mathrm{CuSO}_{4} \cdot 5 \mathrm{H}_{2} \mathrm{O}\right)$ and $3 \mathrm{~g}$ citric acid crystals in 100 ml of distilled water. This will make a $10 \%$ solution which is added at 1 drop/gallon water. Keep in mind that a 20 gallon aquarium does not contain 20 gallons of water when bottom media and habitat have been added.

A cure commonly recommended is to increase the temperature. While it sounds good, the advice is bad. (1) It puts the fish under tremendous stress which means the disease gets a better foothold. (2) It does not cause the disease to "burn" itself out in 5, 7, or 8 days as claimed. It takes at least 14 days in high temperatures to stop most disease cycles. In all cases, increased heat only compounds the problem.

There is an excellent book on the treatment of marine fish diseases, Dr. Kingsford's Treatment of Exotic Marine Fish Diseases, which gives the methods to cure various diseases, the duration of treatment, and the concentrations of chemicals required to effect a cure.

Remember that disease spots, wounds, and frayed fins do not disappear or heal instantly. It will take 2, 3 or more days for the situation to clear up and in some cases, it may require a second treatment a week later to remove all traces of the disease. This is why an ultraviolet system is important because it attacks disease causing organisms in the water column, preventing them from passing from one fish to another while maintaining good water quality. In addition, germicidal ultraviolet lights 
are capable of breaking down organic matter in the water without changing the basic water chemistry, and you cannot overdose with ultraviolet. The one important point to always remember is exposure to the germicidal ultraviolet light can cause blindness to you or the fish and that is why the light must be shielded when it is turned on. I run my UV system all the time and replace the bulbs once a year. I feel it is the ultraviolet that has permitted me to keep fish for 6-7 years without any medication or special treatment and maintain more fish/tank than general filtration calculations suggest.

The best way to prevent disease is to choose your fish carefully. If you dive for your own, collect them from clean water areas and do a preventative dip and medicate them before you introduce new fish to your main tank. Learn about a pet store before you buy fish. A good store owner will work with you. You should expect healthy fish and long survival if you place them in a balanced tank. If you can, be sure the fish are feeding before you purchase them. Most good aquarium stores hold fish from new shipments until they have been medicated and are actively feeding. Remember that you have an obligation to your pet store owner, as well. If you goof and do something wrong, don't blame it on the store.

One of the little tricks I do with store bought fish is in the manner in which I acclimate them to my tanks. I float them in their sealed bags in my medicine tank until I feel the water temperatures are both the same. Then, I open the bagged fish and add some of my tank water to it - being very careful not to get any of the pet store water into my tank, wait 15 minutes and then pour out and discard all the water in the bag, catching the fish in a net and put only the fish into the medicine tank. Most pet stores doing good business have two or three shipments or sources of fish 
each week and medicate their systems. I do not want any of the problems they might have inherited from their shippers nor do I want their medications to upset my tank, so I don't mix their water with mine. There are lots of excellent marine disease treatments on the commercial market. Try them and find out which best serves your setup and situation. Saltwater aquariums can be a rewarding, satisfying hobby. There are more than 600 members of the Florida Marine Aquarium Society in the Miami area alone and there are thousands of hobbyists across the country who are very willing to help and share their ideas, techniques, and enthusiasm with you.

If you follow the ideas I've outlined, you should discover the pleasures and joys of a saltwater aquarium. And best of all, you should have success with the fewest possible problems. 
Books that Help...

Anemonefishes, Dr. Gerald R. Allen, T.F.H. Publications.

Anemonefishes of the World, Dr. Gerald R. Allen, Aquarium Systems, Mentor, Ohio.

Damselfishes of the South Seas, Dr. Gerald R. Allen, T.F.H. Publications.

Butterflyfishes and Angelfishes, Vol. 2, Dr. Gerald R. Allen, Wiley

Interscience Publications.

Butterflyfishes of the World, Dr. Warren E. Burgess, T.F.H. Publications.

Pacific Marine Fishes, Books 1-7, Dr. Warren E. Burgess and Dr. Herbert R. Axelrod, F.F.H. Publications.

Caribbean Reef Invertebrates and Plants, Dr. Patrick Colin, T.F.H.

Publications.

Neon Gobies, Dr. Patrick Colin, T.F.H. Publications.

The Marine Aquarium in Theory and Practice, Dr. C.W. Emmens, T.F.H.

$\overline{\text { Publications. }}$

Marine Aquarium, Frank de Graaf, Pet Library.

The Tropical Marine Aquarium, Vincent B. Hargreaves, McGraw Hill.

Treatment of Exotic Marine Fish Diseases and The Marine Aquarium

Compatibility Guide, Dr. Kingsford, M.D., The Palmetto Publishing Co.

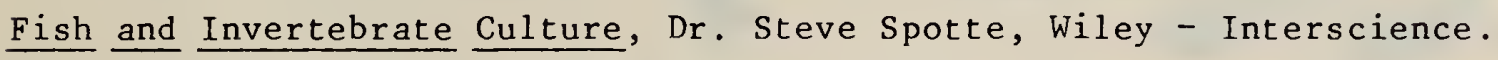

Marine Aquarium Keeping, Dr. Steve Spotte, Wiley Interscience.

Butterfly and Angelfishes of the World, Vol. 1, Roger C. Steene, Wiley Interscience Publications.

Reef fish. Ronald E. Thresher, Palmetto Publishing Co.

The Saltwater Aquarium Manual. Dr. Robert Valenti, Aquarium Stock Co.

Tropical Marine Invertebrates of South Florida and the Bahama Islands, Warren Zeiller, John C. Wiley and Sons.

Tropical Marine Fishes, Warren Zeiller, A.B. Barnes Publisher.

Monthly Magazines

Freshwater and Marine Aquarium Magazine, Subscription Dept., P.O. Box 487, Sierra Madre, CA 91024. 
THE BIOLOGY OF MARINE AQUARIUM FISHES COLLECTED IN MONROE COUNTY. FLORIDA
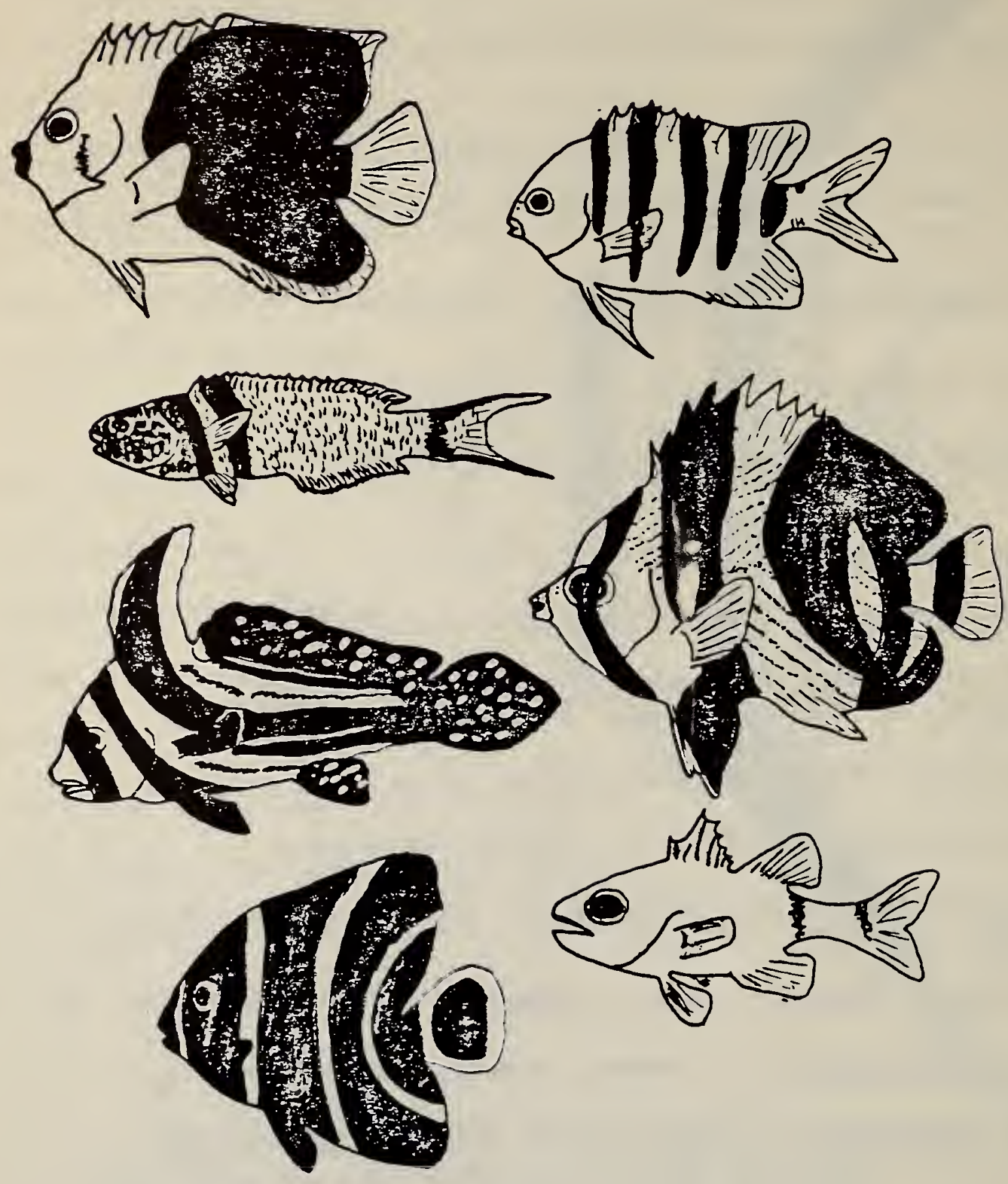

by

Deb Hess and John Stevely

MARINE RESOURCE INVENTORY MONROE COUNTY NIARINE ADVISORY PROGRAM FLORIDA COOPERATIVE EXTENSION SERVICE 


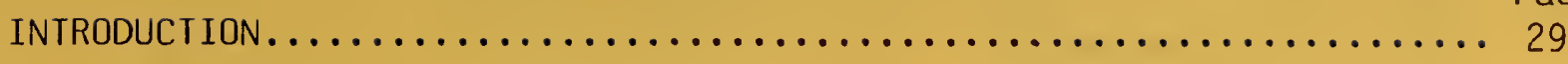

1. CHAETODONTIDAE: ANGELFISHES AND BUTTERFLYFISHES $\ldots \ldots \ldots \ldots \ldots .30$

1.l. Description of the Commercially Valuable Species

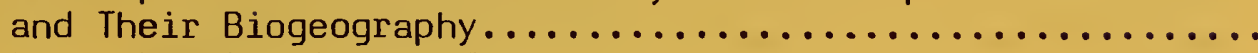

1.2. Local Habitat in the Florida Keys $\ldots \ldots \ldots \ldots \ldots \ldots \ldots \ldots \ldots \ldots \ldots \ldots \ldots, 34$

1.3. Food Habits..................................... 35

1.4. Predation.................................... 36

1.5. Reproduction.................................... 36

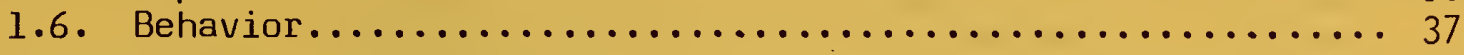

2. POMACENTRIDAE: DAMSELFISHES $\ldots \ldots \ldots \ldots \ldots \ldots \ldots \ldots \ldots \ldots \ldots \ldots \ldots \ldots$

2.1. Description of the Commercially Valuable Species and Their Biogeography .......................... 37

2.2. Local Habitat in the Florida Keys.................... 40

2.3. Food Habits.................................. 41

2.4. Predation................................... 41

2.5. Reproduction............................... 41

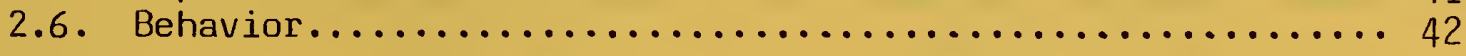

3. APOGONIDAE: CARDINALF ISHES $\ldots \ldots \ldots \ldots \ldots \ldots \ldots \ldots \ldots \ldots \ldots \ldots \ldots \ldots \ldots \ldots$

3.1. Description of the Commercially Valuable Species

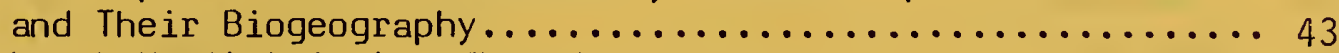

3.2. Local Habitat in the Florida Keys $\ldots \ldots \ldots \ldots \ldots \ldots \ldots \ldots \ldots . . \ldots 4$

3.3. Food Habits $. \ldots \ldots \ldots \ldots \ldots \ldots \ldots \ldots \ldots \ldots \ldots \ldots \ldots \ldots \ldots, 44$

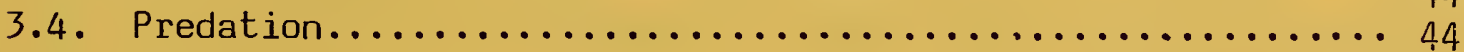

3.5. Reproduction................................... 44

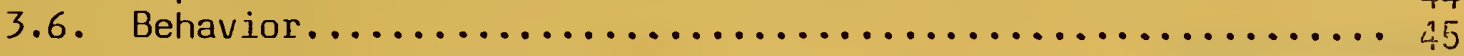

4. OPISTOGNATHIDAE: JAWFISHES $\ldots \ldots \ldots \ldots \ldots \ldots \ldots \ldots \ldots \ldots \ldots \ldots$

4.1. Description of the Commercially Valuable Species and Their Biogeography ........................... 45

4.2. Local Habitat in the Florida Keys.................... 45

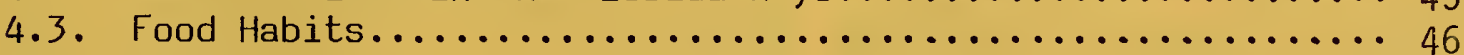

4.4. Predation................................... 46

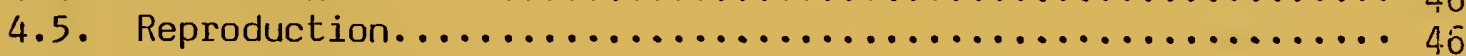

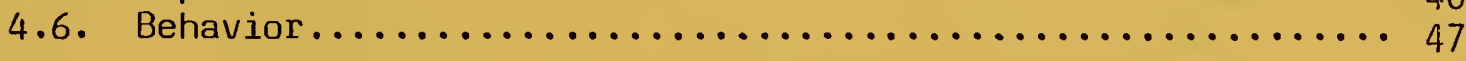

5. SCIAENIDAE: DRUMS AND CROAKERS $\ldots \ldots \ldots \ldots \ldots \ldots \ldots \ldots \ldots \ldots \ldots \ldots \ldots$

5.1. Description of the Commercially Valuable Species and Their Biogeography $. \ldots \ldots \ldots \ldots \ldots \ldots \ldots \ldots \ldots \ldots \ldots, 47$

5.2. Local Habitat in the Florida Keys................... 49

5.3. Food Habits $\ldots \ldots \ldots \ldots \ldots \ldots \ldots \ldots \ldots \ldots \ldots \ldots \ldots \ldots \ldots, \ldots \ldots \ldots, i_{i} 9$

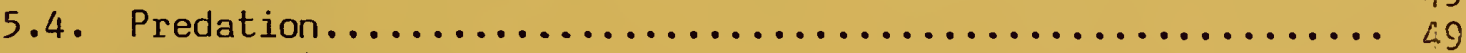

5.5. Reproduction............................. 49

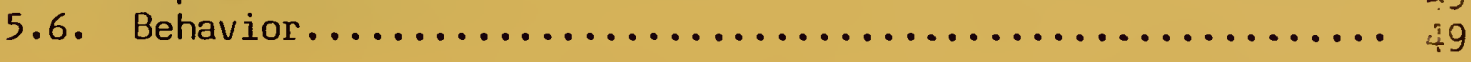


6. BLENNIIDAE: BLENNIES.............................. $\frac{\text { Page }}{49}$ 6.1. Description of the Commercially Valuable Species

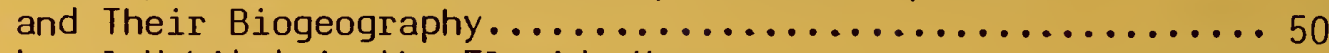

6.2. Local Habitat in the Florida Keys.................. 51

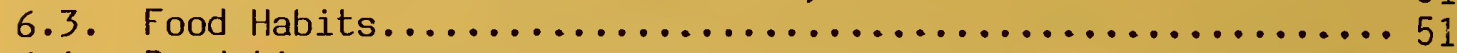

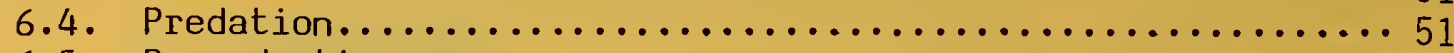

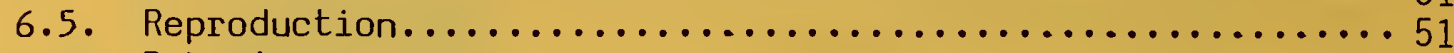

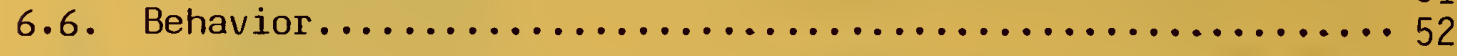

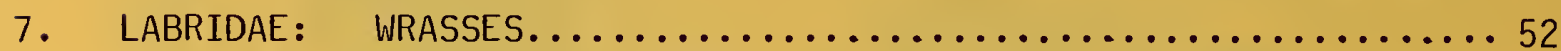

7.1. Description of the Commercially Valuable Species

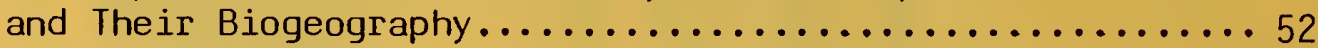

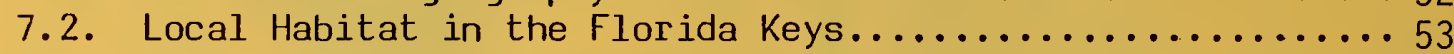

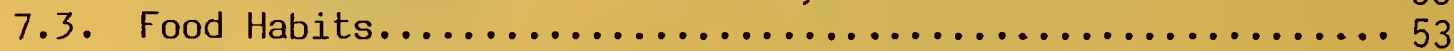

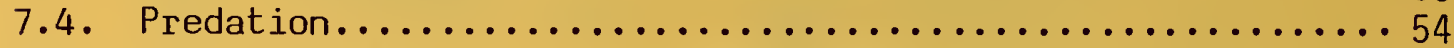

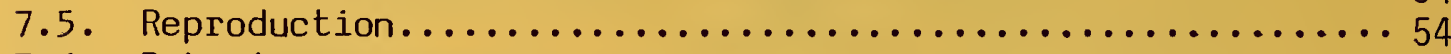

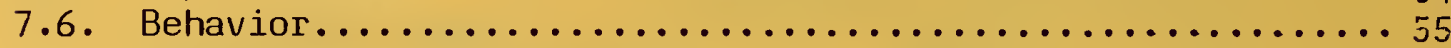

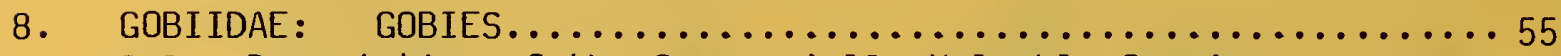

8.1. Description of the Commercially Valuable Species

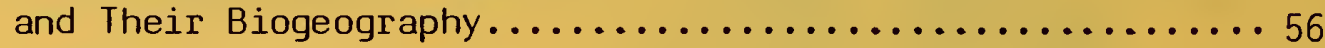

8.2. Local Habitat in the Florida Keys.................. 56

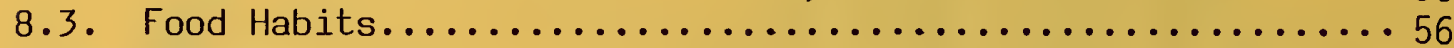

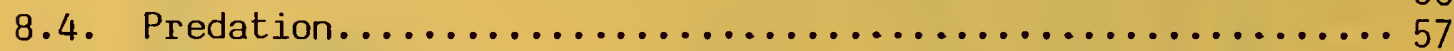

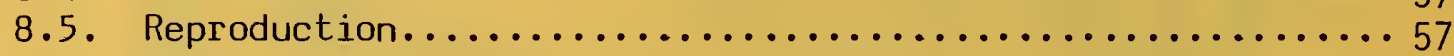

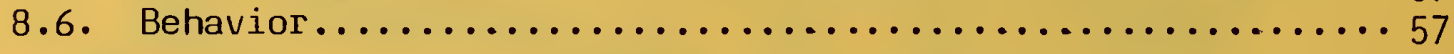

9. DIVERSITY OF TROPICAL CORAL REEF FISH COMMUNITIES $\ldots \ldots \ldots \ldots \ldots 7$

ACKNOWLEDGEMENTS. . . . . . . . . . . . . . . . . . . . . 60

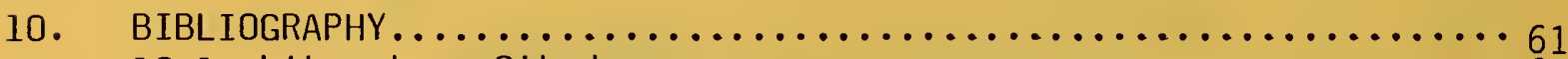

10.1. Literature Cited............................ 61

10.2. Additional References........................ 68

APPENDIX A: DEFINITIONS OF GENERAL TERMINOLOGY $\ldots \ldots \ldots \ldots \ldots \ldots \ldots \ldots 74$

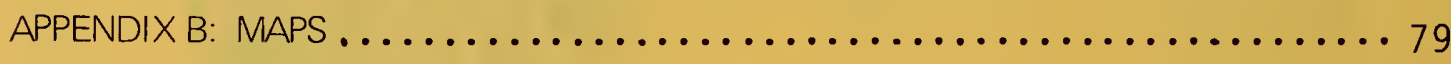

APPENDIX C: COMMONPLANTS AND ANIMALS.................. 81 
THE BIOLOGY OF MARINE AQUARIUM FISHES

COLLECTED IN MONROE COUNTY, FLORIDA

by

Deb Hess and John Stevely

Marine Resource Inventory

Monroe County Marine Advisory Program

Florida Cooperative Extension Service

\section{INTRODUCTION}

Living in close association with coral reefs of the Florida Keys are a wide assortment of interesting and beautiful fishes that are collected for display in home or public aquaria. Exhibition of these fish in aquaria provide hours of entertainment, and for landlocked Americans, provides an educational experience that would othervise be unavailable. To many, these abundant, brightly colored fishes, with their interesting behavoral patterns, are an integral part of the beauty and fascinating biological complexity associated with tropical coral communities. This paper presents a summation of our current understanding of the biology of 8 major families ( 30 species) of fishes that are of primary importance to the aquarium industry and which are collected in the Florida Keys.

This task was primarily undertaken to provide a basis to evaluate what we presently know about these fishes. This was deemed a logical first step in addressing the question of whether increasing fish collecting would affect natural abundance--a question being increasingly voiced by concerned citizens. A description of the collection industry and preliminary analysis of its magnitude has also been prepared by the present writers (Hess and Stevely, 1978, The Aquarium Reef Fish Collecting Industry of Monroe County: Monroe County Florida Cooperative Extension Service, unpublished).

Summarizing and organizing all existing information on 30 species of fishes was a somewhat taxing problem, and the reader will benefit from a few pointers on how this paper can best be used. Because the use of non-familiar technical language cannot always be avoided, Appendix A, an illustrative definition of many technical phrases, has been included (parenthetical Roman Numerals within the text refer the reader to the appropriate definition in Appendix A). Maps showing the areas referred to in the Caribbean and Florida Keys (Appendix B), and illustrations of invertebrates and plants commonly mentioned in the text (Appendix C) are also included. Lengthy, detailed information is presented in some sections of the paper. Therefore, the reader not interested in such coverage may best be served by skipping over these sections, or by using the paper as a valuable reference--providing valuable information when a particular question arises. An extensive bibliography provides those seeking additional information with a valuable introduction to the available literature. 


\section{CHAETODONTIDAE: ANGELFISHES AND BUTTERFLYFISHES}

Angelfishes and Butterflyfishes are brightly colored fishes associated with coral reefs around the world. Because of their beautiful coloration and interesting shapes, they are popular aquarium fishes. Presently, the angelfishes dominate the aquarium fish market in the Keys. They are among the few species collected in these waters that can compete in popularity with Indo-Pacific and Pacific imported fishes. Juvenile angelfishes exceeding two inches in length seem to fare best on the aquarium market; smaller fishes have very specific food requirements and frequently will die in captivity. All angelfishes and butterflyfishes require small morsels of food, are slow eaters, require clean salt water, and hiding places.

\subsection{Description of the Commercially Valuable Species and Their Biogeography.}

The name Chaetodontidae is derived from Greek words meaning "bristle tooth" or "hair tooth". These disc-shaped fishes have small protractile (capable of being thrust out) mouths, with slender, brush-like teeth (III). Two important subfamilies are recognized: Chaetodontinae (butterflyfishes) and Pomacanthinae (angelfishes). Burgess (1974) elevated angelfishes to the family Pomacanthiniae, leaving butterflyfishes as the family Chaetodontidae, but the movement is still debated among ichthyologists.

Butterflyfishes and juvenile angelfishes have evolved an interesting form of disruptive coloration: prominent dark vertical stripes and/or a dark spot near the caudal $\mathrm{fin}$. This may be of considerable adaptive significance.

The coloration breaks up continuity of shape, and more importantly, the stripe through the eye and the dark spot near the caudal fin (which resembles an eye) may confuse a predator. Since predators frequently home in on the eyes of prey during attack, the predator, confusing the spot for an eye, may attack the rear of the fish and misjudge the anticipated direction of flight.

\section{Angelfishes}

Queen Angelfish, Holacanthus ciliaris Linnaeus 1758
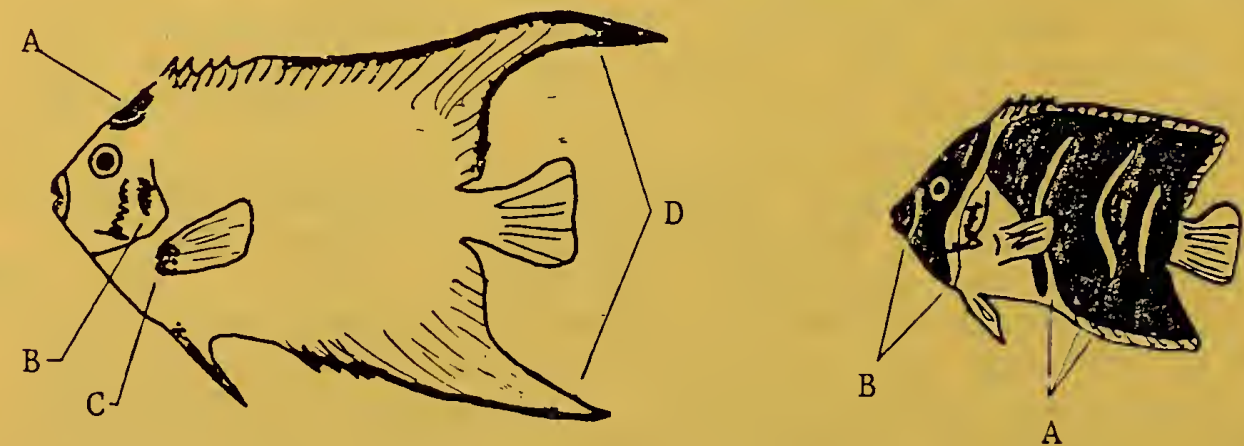

The Queen angelfish is purplish-blue with an orange-yellow trim on the scales. Above the eye is a dark blue area; below it, a greenish-yellow area. The mouth, chin, throat, and abdomen are purplish-blue. On the forehead there 
is a large distinct blue-edged spot (A), there is a bright blue blotch on the gill cover (B), and a blue and black blotch at the pectoral $f$ in base $(C)$. The paired fins are yellow, the caudal fin orange-yellow, and the dorsal and anal fins orange with blue edges (D). The brilliant blue and yellow distinguish it from all other angelfishes except the Blue angelfish, which is similar in appearance but lacks the blue-edged black spot ( $A$ ) and has a yellow rim only around its blue caudal fin. Adults reach $46 \mathrm{~cm}$ (18 in.) in length. The Queen angelfish occurs throughout tropical waters, including the southern Gulf of Mexico, and from the coast of Florida to Brazil.

Juvenile Queen angelfish have three light blue bars on the body $(A)$, and two on the head (B). There is a dark band through the eye. As the fish grows, these bands increase in number, then gradually disappear.

Blue Angelfish, Holacanthus bermudensis Jordan and Rutter 1898
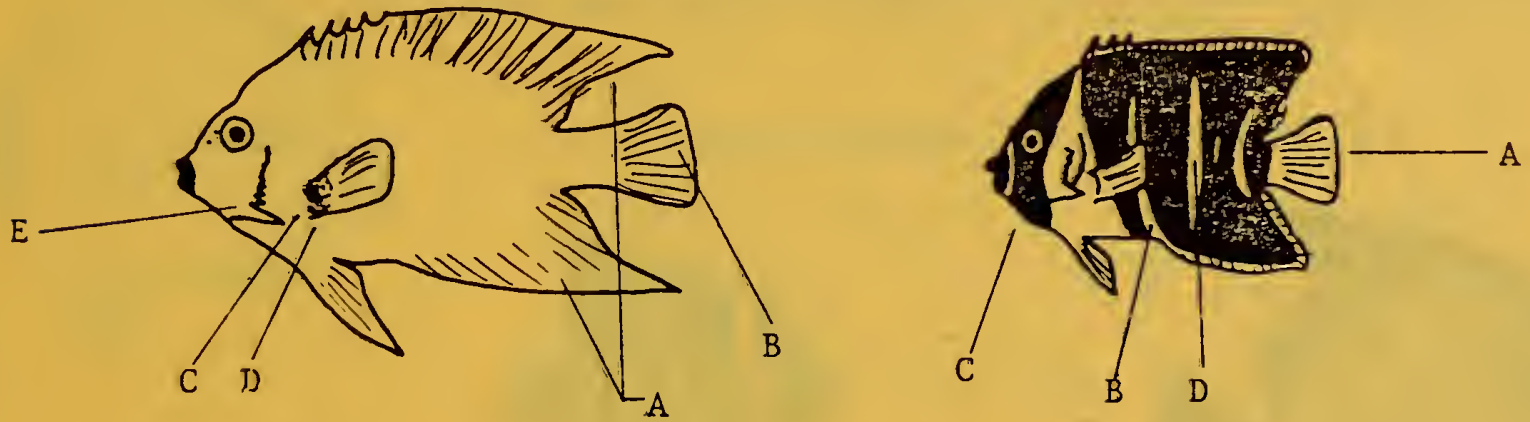

The Blue angelfish has yellowish-brown to purplish-brown scales with pale edges. The dorsal and anal fins have blue margins ( $A$ ) except the ends are yellow. The caudal $f$ in is yellow at the end $(B)$, but darker toward the base. The pectoral fins have blue at their base (C), a yellow band (D), and then turn transparent. There is a large, prominent preopercular spine (E) and several smaller spines which are all blue. The adults reach $46 \mathrm{~cm}$ (18 in.) in length. The Blue angelfish occurs in the West Indies, Bermuda, Florida, and the Gulf of Mexico.

Juveniles have a yellow caudal $f$ in (A), blue bars on the body and head (B), and a dark area between the two bars on the head ( $C$ ), as do juvenile Queen angelfishes. The two can de differentiated by the second body bar which is straight in the juvenile Blue angelfish (D) and curved in the juvenile Queen angelfish.

\section{Gray Angelfish, Pomacanthus arcuatus Linnaeus 1787}

The scales of the Gray angelfish are edged in light brown, the larger scales having a dark brownish-gray spot in the center. The caudal $f$ in has a lightish border (A), the inside of the pectoral fins are yellow (B), and the dorsal and anal $f$ ins probonged in adults and sub-adults (C). There is a large spine on the preopercule (D) and the lips are white (E). The adult Gray angelfish may reach $50 \mathrm{~cm}$ (24 in.) in length. The Grey angelfish is found on both sides of the Atlantic, on the western side from New England to Brazil, including the Gulf of Mexico. This species has been introduced into Bermuda. 

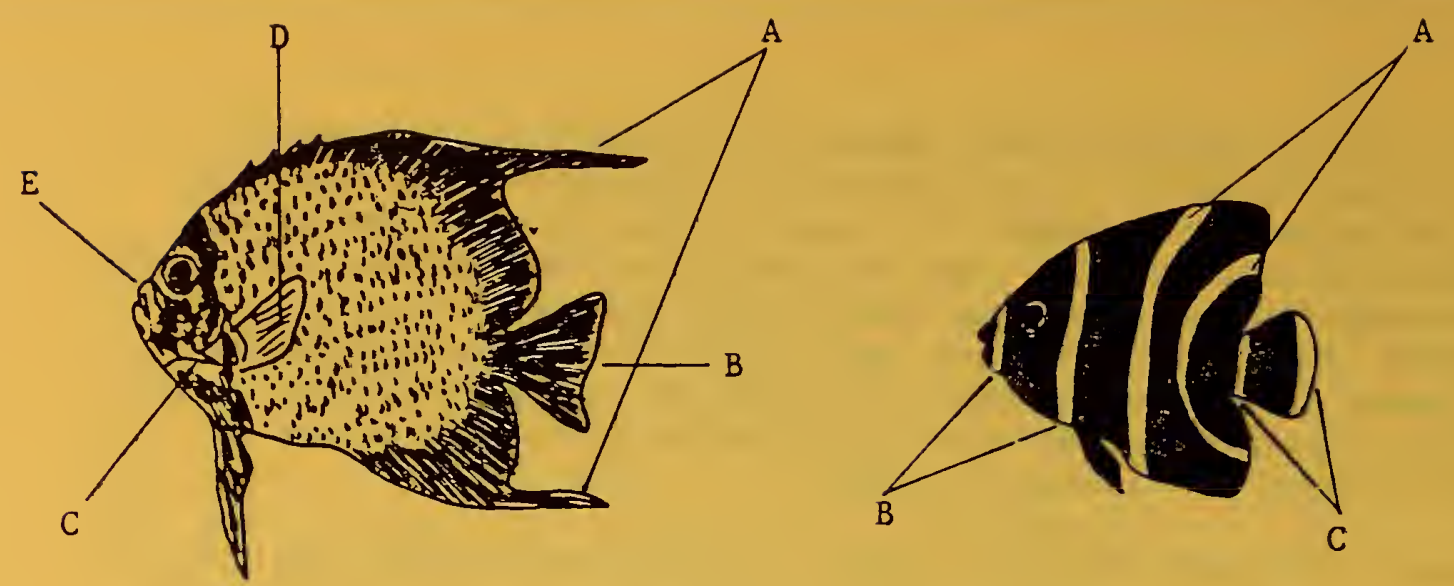

Juveniles differ tremendously in coloration. The young are black with two light yellow bars on the body (A), and two yellow bars on the head (B). The caudal $f$ in has two yellow bars (C) with a black area inside. The bars may be present in older juveniles even after the spotted brown adult color is gained.

French Angelfish, Pomacanthus paru Bloch 1787
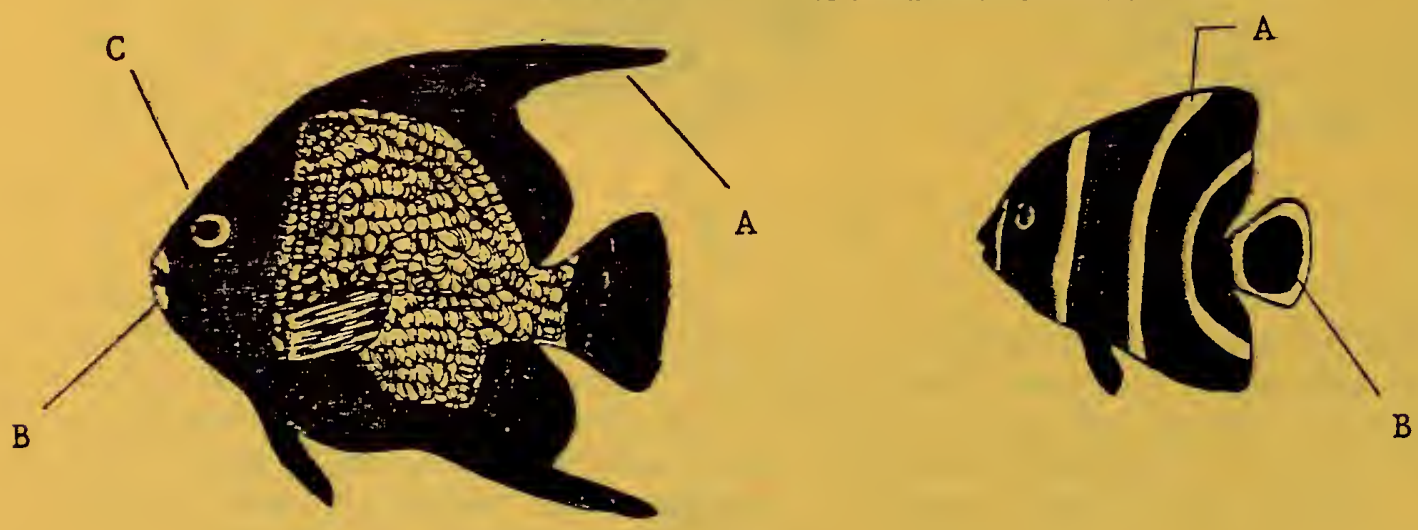

The French angelfish is primarily black; hovever, the scales of the body are rimmed with golden yellow. The dorsal $f$ in filament is yellow $(A)$, the chin whitish (B), and the outer iris is yellow (C). Maximum size for the French angelfish is $41 \mathrm{~cm}$ (16 in.). The French angelfish is found on both sides of the Atlantic, in the vestern Atlantic from the Bahamas and Florida to southeast Brazil. This species has been introduced into Bermuda.

Juvenile French angelfish strongly resemble juvenile Gray angelfish, the body black with yellow stripes $(A)$; however, the juvenile French angelfish has a round black spots in the caudal $f$ in (B) whereas, in the juvenile Gray angelfish, this spot is rectangular. The center yellow nose stripe on a juvenile French angelfish stops at the upper lip while it continues through the lower lip on a Grey angelfish juvenile.

Rock Beauty, Holacanthus tricolor Bloch 1795
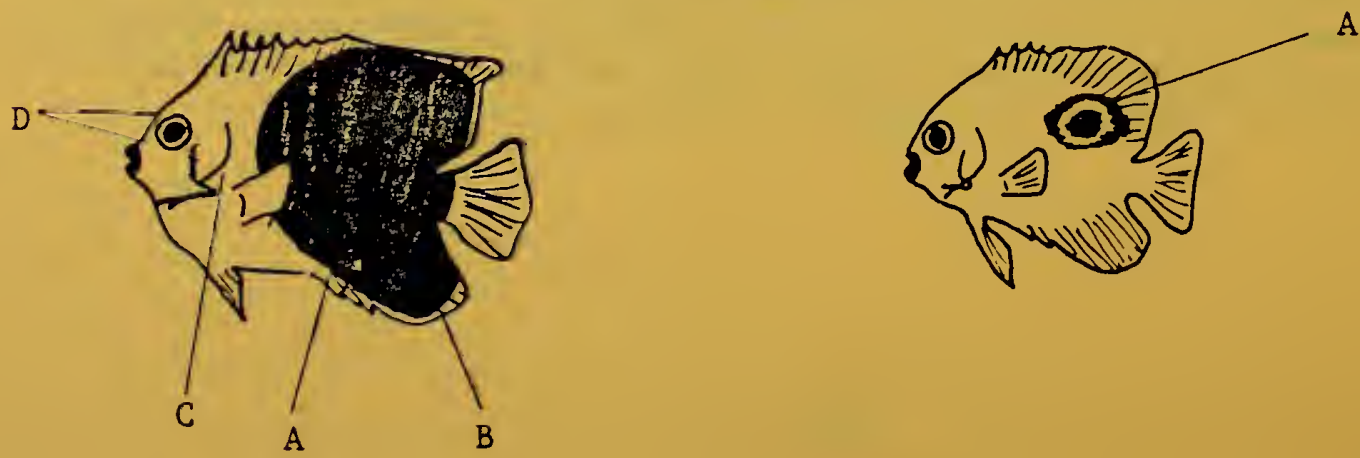
In the Rock Beauty, the back half of the fish is black (A); the remainder yellow. The front margins of the anal $f$ in (B) and the edge of the gill cover are orange (C). There are bright blue areas on the upper and lower parts of the iris (D). Adults of this species attain $30 \mathrm{~cm}$ (12 in.) in length. The Rock Beauty is found in Bermuda, the Bahamas, and from Florida to Brazil.

Juveniles of about $2 \mathrm{~cm}$ ( 1 in.) in length are entirely yellow except for a blue-edged black spot (A) that, with age, increases in size until it covers most of the body in the adult.

\section{Butterflyfishes}

Foureye Butterflyfish, Chaetodon capistratus Linnaeus 1758

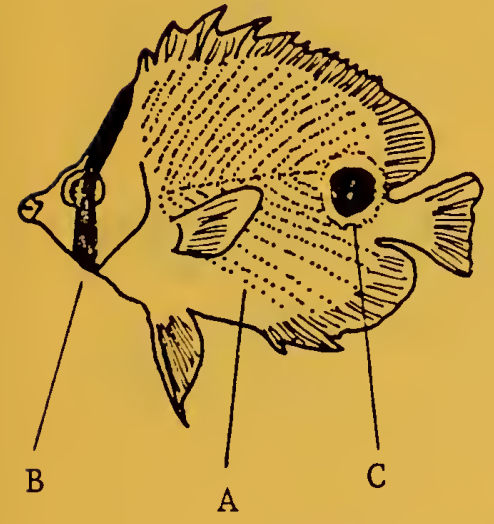

During daylight hours, the Foureye butterflyfish is light gray to pale yellowish on the sides. Two sets of diagonal dark lines (A) cover much of the body; a black bar cuts through the eye (B); and there is a large white-edged black spot in the rear (C). During the evening, this species displays two broad, dusky bars on each side, to blend into coral cravices where it hides. The Foureye butterflyfish grows to $10 \mathrm{~cm}$ (4 in.) in length. It is found from Massachusetts to the Lesser Antilles in the vestern Atlantic and in the Gulf of Mexico.

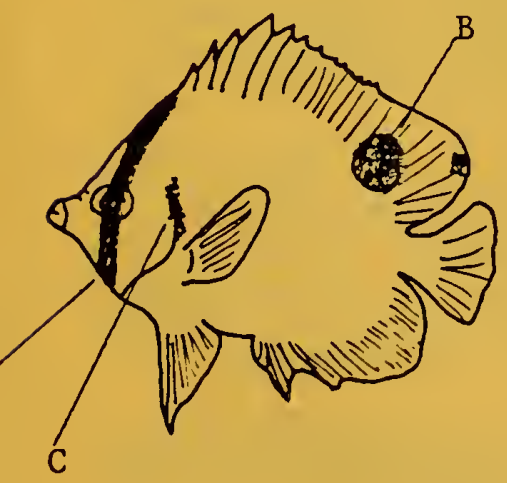

The Spotfin biutterflyfish has a white body, with the dorsal, pelvic, anal, and caudal fins yellow. There is a black bar through the eye (A), and a large black spot in the dorsal $f$ in $(B)$. A narrow yellow bar is located along the gill opening (C). This species grows to $18-20 \mathrm{~cm}$ (7-8 in.) and is the largest butterflyfish in the Florida Keys. The Spotfin butterflyfish is found from Massachusetts to Brazil, and in the Gulf of Mexico.

Reef Butterflyfish, Chaetodon sedentarius Poey 1860

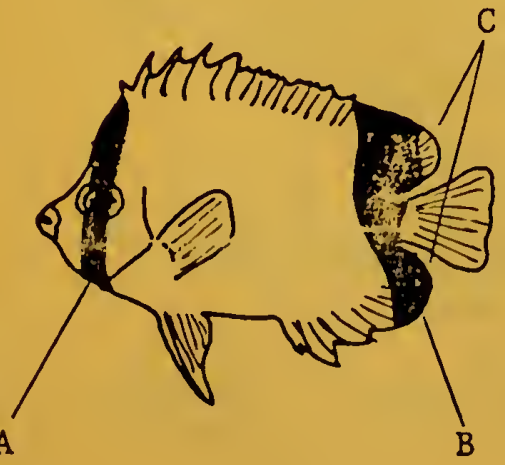

The coloration of the Reef butterflyfish is white; hovever, the upper part of the body is yellow. There is a black bar through the eye (A), and a broader dark area near the tail (B). The rear side of the dorsal and anal $f$ ins are rounded (C). This species reaches $14 \mathrm{~cm}$ ( $5.5 \mathrm{in.}$ ) in length. The Reef butterflyfish occurs from North Carolina to Florida, in the West Indies, the Caribbean Sea, and the Gulf of Mexico. 


\section{Banded Butterflyfish, Chaetodon striatus Linnaeus 1758}

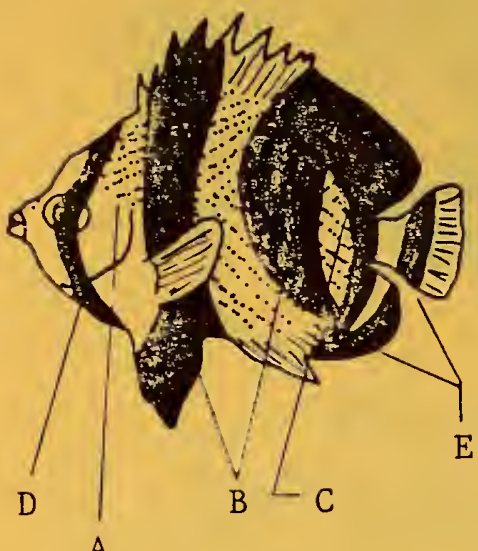

A
The Banded butterflyfish is white and has the same diagonal dark lines $(A)$ as the Foureye butterflyfish. In addition, two broad black bars are on the side of the body (B) and a third less distinct bar is in the rear of the body (C). Again, a dark bar cuts through the eye (D) and there are bands in the dorsal, anal, and caudal fins (E). This species reaches $15 \mathrm{~cm}$ (6 in.) in length. The Banded butterflyfish occurs on both sides of the Atlantic; on the western side from New Jersey to Brazil, and in the Gulf of Mexico.

\subsection{Local Habitat in the Florida Keys}

In the Florida Keys, researchers have described the habitat of angelfishes (Feddern 1968, Straughan 1973) and butterflyfishes. (Straughan 1973). Unless otherwise noted, the following habitat descriptions are taken from these studies.

\section{Angelfishes}

Feddern (1968) described five habitats of angelfishes in the upper Florida Keys:

1) Inshore channel habitat: Fairly uniform rock bottom, a few sandy spots, abundant growth of Finger coral (Porites sp.), gorgonians, and calcareous algae (Halimeda sp.). Currents are swift during flood and ebb tides, the water turbid.

2) Bridge pilings: Sandy or smooth rock bottom with sponges, algae, coral, and other fouling organisms which occur primarily on the pilins themselves. Currents are extremely swift, water clarity is dependent on the tide.

3) Coral heads: Coral heads up to $3 \mathrm{~m}$ (10 ft.) across, 3 to $6 \mathrm{~m}$ (10 to $20 \mathrm{ft}$.$) in depth with extensive sponge grouth vere sampled. Coral$ heads vere primarily Star coral (Montastrea annularis), a boulderlike species that thrives in inshore areas (Hawk's Channel).

4) Reef top: Five to $8 \mathrm{~km}$ ( 3 to $5 \mathrm{mi}$ ) ) offshore with 1 to $6 \mathrm{~m}$ ( 3 to $19 \mathrm{f}$ of water overhead. Bottom consisted of very eroded rock densely covered with algae and gorgonians. There are many attached and encrusting sponges, and Fire coral (Millepora sp.).

5) Deep reef: The deep reef occurs on a steep slope $18-33 \mathrm{~m}$ (54-99 ft.) in depth. It consists of eroded rock with channels and supports a dense grouth of corals, gorgonians, sponges, and sparse algae.

Feddern commented on juvenile and adult angelfish distribution in general, and pointed out that juveniles are commonly found solitarily in and around 
colonies of Finger sponge (Neopetrosin sp.) and Fire coral, and that they seldom venture into open waters. Adults are found around large objects such as rocks, ledges, pilings, and coral heads, and swim more freely in open waters. Causey (pers. commun.) has reported similar observations.

Queen Angelfish: Queen angelfish are common around bridge pilings, inshore coral heads and on the outer reefs. Juveniles are especially abundant on the reef top habitat.

Blue Angelfish: Blue angelfish are common in the shallow water and inshore channel habitats (they dominate angelfish populations present on bridge pilings) and are common on coral heads and the outer reefs. Straughan (1973) reported the highest concentrations of angelfishes on the bridge pilings.

Gray Angelfish: Gray angelfish occur on the bridge pilings; however, they are most prevalent on the coral heads and nearshore patch environments. This species occurs occasionally on the reef top and deep reef. Juveniles can be found in the inshore channels as well.

French Angelfish: French angelfish occur on the bridge pilings and occur occasionally in all other habitats.

Rock Beauty: The Rock Beauty is found in coral rocky areas, offshore in outer reef habitats. It is also found in the mid-channel reefs (a shallow reef area running through the middle of Hawk's Channel).

\section{Butterflyfishes}

Foureye Butterflyfish: This species is found in shallow sponge flats and around Finger coral as juveniles, as well as in Hawk's Channel, and around Staghorn coral (Acropora cervicornis) as adults. In the warmer months, the Foureye butterflyfish can be found in extremely shallow water, especially around the Long-spined sea urchin (Diadema antillarm). This is the most common butterflyfish in the Bahamas (Bohlke and Chaplin 1968). It is common and plentiful here in the Florida Keys from the backcountry (Gulf side of the Keys) to the Atlantic reefs.

Spotfin Butterflyfish: This species is locally abundant in shallow water in the spring through fall, and on the outer reefs year round.

Reef Butterflyfish: This species seems to prefer the $30-50 \mathrm{~m}$ (80-150 ft.) deeper waters and is locally common on the outer reefs.

Banded Butterflyfish: Like the Spotfin butterflyfish, this species is found in shallow waters in the spring through fall, and on the outer reefs.

\subsection{Food Habits}

Angelfishes feed primarily on sponges. Feddern (1968) described angelfishes as the most important sponge feeders in south Florida. However, he found that the percentage of sponge consumed varied with species and habitat, with the 
non-sponge portion of the diet consisting of algae. He further noted that although the Rock Beauty, Queen, and Blue angelfish consumed primarily sponge, the French and Gray angelfish consumed varying amounts of sponge and algae, depending on habitat sampled.

Randall (1967) reported angelfishes to prefer sponges with siliceous spicules (small glass-like particles, V) which are eaten successfully because a tough mucous is secreted around the food mass to protect the stomach. The two major types of sponge eaten by angelfishes have a low spicule content relative to organic matter, reducing the spicule effect somewhat, but they have a large amount of fibrous protein material in the form of spongin, making digestion difficult (Randall and Hartman 1968).

Like adults, juvenile angelfish consume sponge and algae. However, juveniles may also feed by picking parasites (IV) off larger fishes. This interesting biological relationship is referred to as "cleaning" and is seen in many marine animals (Holson 1969). Randall (1967) reported filaments of algae and copepods in young angelfishes. Feddern (1968) found similar stomach contents in adults and juveniles and reported parasite picking to be a small portion of the diet.

The butterflyfishes, according to Randall (1967, 1968), fed primarily on tentacles of polychaete worms and zoanthonians (colonial sea anemonies). Alevizon and Brooks (1975) found that butterflyfishes fed primarily on coral polyps. These fishes have long, thin snouts, well adapted to a picking habit that permits them to snip coral polyps from the coral surface.

\subsection{Predation}

There are few reports of predation on angelfishes and butterflyfishes in the literature. However, Dragovich (1959, 1970 as cited in Aiken 1975) reported juveniles consumed by seven species of Atlantic tunas, especially the Skipjack (Katsuwanus pelamis) and Yellowfin (Thunnus albacares). Randall (1967) recorded a Rock Beauty in the stomach of the Dog Snapper (Lut janus jocu).

\subsection{Reproduction}

Munroe et al. (1973) and Aiken (1975) studied angelfishes and butterflyfishes in Jamaican waters and found that, in more than 40\% of the species studied, reproductive activity was apparent in all months. Maximum spavning activity occurred between December and March.

Many times in the literature, these fishes have been reported to travel in pairs (Bohlke and Chaplin 1968; Randall 1968; Straughan 1973; and Aiken 1975). These pairs seem to form and reform; there is no evidence of a permanent pair bond (Moe, pers. commun.). No large spawning aggregations have been described. Straughan (1973) reported the Blue angelfish spawning in the area of Finger sponge and dense beds of Finger coral, as well as around large Loggerhead sponges (Spheriospongin nesparia). Straughan (1973) indicated similar spawning habitats for other angelfishes and butterflyfishes. 
Since these fishes lack intromittent organs, fertilization is probably external (Aiken 1975). There appears to be little movement from the home ranges of angelfishes and butterflyfishes during spawning (Causey, pers. commun.).

Aiken (1975) estimated the number of eggs in ovaries of seven species of Chaetodontids and concluded that butterflyfishes produce more eggs per unit of body weight compared to angelfishes. Number of eggs produced per individual was usually in the tens of thousands.

Breder and Rosen (1966) reported angelfishes and butterflyfishes to have pelagic (floating) eggs. Scotton and de Sylva (1972) found larval butterflyfishes in Gulf Stream waters. Moe (1977) reported rearing Gray angelfish and confirms that angelfishes spawn smooth, pelagic eggs of $1 \mathrm{~mm}$ or less, and have a three week pelagic larval stage. Hatching requires 15-30 hours in varm water $\left(70^{\circ}-80^{\mathrm{F}}\right)$. The larvae are vell developed upon hatching and can feed themselves within two days (Moe 1977). Where the eggs and larvae travel after release by the female is unknown.

\subsection{Behavior}

Starck and Davis (1966), from their studies on Alligator Reef, pointed out, "Chaetodontids are active, diurnal (daytime) browsers (IV) all more or less inactive at night". The Rock Beauty, Blue, and Queen angelfish rested in holes and under ledges at night, were inactive, and only responded sluggishly to divers. Several species of butterflyfish were also inactive at night, but responded to divers. The Gray and French angelfish are more darkly colored than the others and, therefore, can rest safely in more open locations, usually next to a rock or large sponge.

Tagging experiments (Bardock 1958, Springer and McErlean 1962, and Moe 1972) have shown these fishes to have a small fixed home range. Wilson (1975) defines home range as that area which an animal learns thoroughly and habitually patrols for long periods.

Angelfishes and butterflyfishes are often sighted solitarily or in pairs. Juvenile angelfishes and butterflyfishes remain close to shelter areas, drawing back into crevices and holes as potential danger nears.

\section{POMACENTRIDAE: DAMSELF ISHES}

The damselfishes are a family of small, tropical, inshore, and reef dwelling fishes. These fishes are characteristically extremely territorial in nature, especially during reproductive periods when males are guarding eggs. Damselfishes are hardy aquarium fishes and do vell in aquaria as long as territorial species are separated to avoid fighting. Their hardiness, variety in shape and color, and abundance, have made damselfishes popular among collectors in the Florida Keys.

\subsection{Description of the Commercially Valuable Species and Their Biogeography}

Damselfishes have one distinctive family characteristic making them easy to identify from similar fishes: a single nostril on either side of the snout (as opposed to the normal two). Bohlke and Chaplin (1968) reported twelve species of damsel fishes occurring in the Bahamas and adjacent waters. 
Emery (1973) reported fourteen species at Alligator Reef. Eight species are considered here.

The following descriptions and biogeographies are adapted from Bohlke and Chaplin (1968) and Randall (1968). Juvenile damselfishes are, in general, much more brightly colored and spotted than the adults.

Threespot Damselfish, Eupomacentrus planifrons Cuvier and Valenciennes 1830

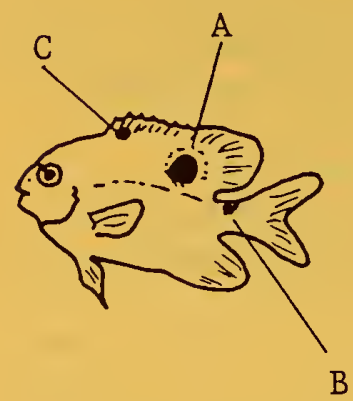

Adult Threespot damselfish are brownishyellow with a large black spot at the dorsal $f$ in base $(A)$. The juveniles are bright yellow, with the large blackish spot faintly edged in blue and two other black spots, one on the caudal peduncle (B), and one at the upper dorsal $\mathrm{f}$ in base $(C)$. This species reaches $13 \mathrm{~cm}$ (5 in.) in length.

The Threespot damselfish occurs from south Florida, Bermuda, and the southwest Gulf of Mexico, through the Caribbean Sea and the Bahamas, south of the Lesser Antilles.

Cccoa Damselfish, Eupomacentrus variabilis Costelnau 1855

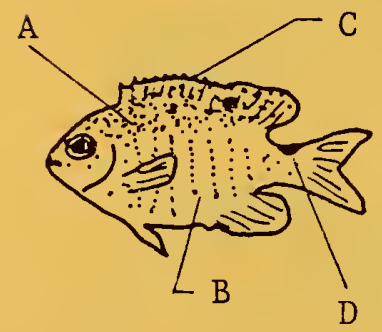

The Cocoa damselfish has a bluish upper body (A), and the lower body is yellowish ( $B$ ). All the fins are also yellowish except the dorsal $f$ in which is blue (C). There is a dark spot in the dorsal $\mathrm{f}$ in as vell. Juveniles have an additional dark mark on the caudal peduncle (D). Maximum size in this species is $10 \mathrm{~cm}$ (4 in.).

The Cocoa damselfish occurs from Florida and the Bahamas to Brazil, including the Gulf of Mexico.

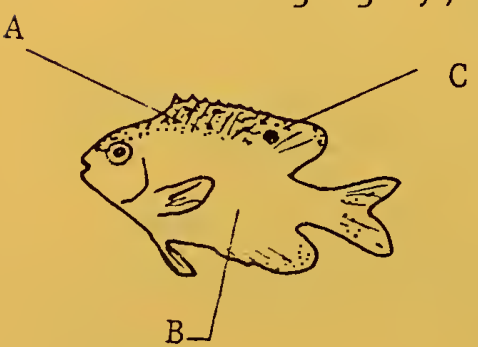

Beaugregory, Eupomacentrus leucostictus Múller and Troschel 1848

The Beaugregory is found on both sides of the Atlantic; on the western side from Maine to Brazil, including Bermuda and the Gulf of Mexico.

Yellowtail Damselfish, Microspathodon chrysurus Cuvier and Valenciennes 1830

Adult yellowtail damselfish are very dark yellowish-brown with scattered, small, iridescent blue spots $(A)$. The caudal $f$ in $(B)$ is bright yellow in adults, and almost transparent in juveniles. Juveniles are dark blue with many large, bright, metallic blue spots, resulting in the juveniles often being termed "jevel fish". This species reaches $19 \mathrm{~cm}$ ( $7.5 \mathrm{in.})$ in length. 
Like the Beaugregory, the Yellowtail damselfish is found on both sides of the Atlantic; on the western side from Bermuda, Florida, and the Bahamas, to Brazil, including the Gulf of Mexico.

Sergeant Major, Abudefduf saxatilis Linnaeus 1758

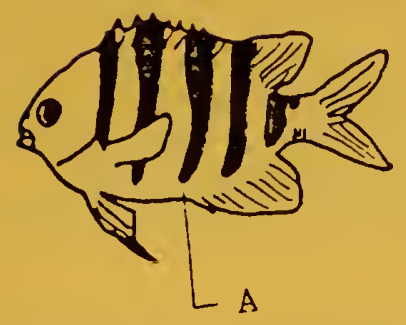

The Sergeant Major has two color phases; the phase displayed being dependent on the habitat it is in. When a lightly colored habitat, the body is bluish-white, the upper body yellow; however, as the environment darkens, so does the fish, assuming a dark grey appearance. The Sergeant Major derives his name from the five blackish bars that span the body $(A)$ in either color phase. Adults reach a maximum of $18 \mathrm{~cm}$ ( 7 in.).

The Sergeant Major can be found in warm waters wor]dwide. In the western Atlantic, this fish occurs from New England to Uruguay, including the Gulf of Mexico.

Honey Gregory, Eupomacentrus mellis

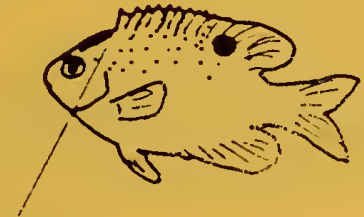

A

The Honey Gregory is a smaller damselfish, the adults growing to $6.3 \mathrm{~cm}(2.5 \mathrm{in.})$. They are predominantly yellow, with blue bars and dots in the head region (A). Variation in coloration with age appears insignificant in this species (Goodson 1976). Aquarists Stan Becker and Tom Reid (pers. commun. as cited in Emery 1973) preferred this species because it holds its color in aquaria while other similarly colored species tend to fade.

The Honey Gregory abounds from the Bahamas and Florida, through the West Indies, south of Venezuela (Goodson 1976).

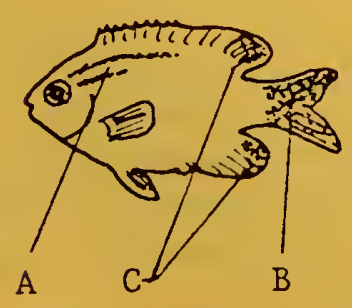

Yellowtail Reeffish, Chromis enchrysurus

This species has two violet stripes near the eye (A) and a yellow tail (B). The ends of the dorsal and anal fins are also yellow (C). The body is a bluish-gray color overall. This species reaches $10 \mathrm{~cm}$ ( $4 \mathrm{in.}$ ) in length.

The Yellowtail Reeffish occurs along both coasts of Florida and southward (Goodson 1976).

Blue Chromis, Chromis cyanea Poey 1869

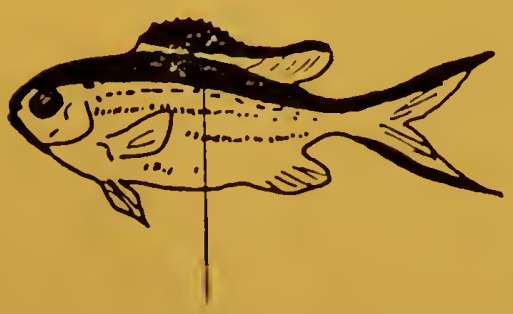

A

The Blue Chromis is a bright blue fish with black trim (A) on the upper body and the edges of the dorsal, caudal, and anal fins. This blue color helps this species blend into the blue Gulf Stream waters where it frequently can be observed schooling above the reef. This species has been recorded to reach $13 \mathrm{~cm}$ (5 in.) in length (Goodson 1976). 
The Blue Chromis occurs from Bermuda, the Bahamas and Florida, south through the Caribbean to the Lesser Antilles.

\subsection{Local Habitat in the Florida Keys}

Damselfishes are found in both nearshore and offshore areas of the Florida Keys, primarily associated with coral heads and reefs. An important morphological (body shape) variation can be used to differentiate the habitat of some damselfishes. Emery (1973) found the rounder fishes with shorter and more rounded caudal $f$ in (I) live on or near the bottom (Threespot damselfish), while those with more oval shaped bodies and longer, more pointed caudal fins swim in large aggregations in mid-water (Blue Chromis). He conducted an extensive study on damselfishes in the Florida Keys. This study was carried out on Alligator Reef where four major habitats were examined: 1) deep reef; 2) reef tops; 3) back reef or lagoon; 4) patch reefs (coral heads ).

The following habitat data was drawn primarily from Emery (1973) unless otherwise referenced.

Threespot Damselfish: Juveniles were rare inshore, but all ages were common on patch reefs. Adults commonly occurred in deep surge channels; usually near coral, the walls of caves, or an obstruction on the bottom. There are many juveniles on the outer reef top just below the Fire coral zone. All ages occur on the deep reef, with considerable variation in abundance.

Cocoa Damselfish: This species is the most widespread of all the damselfishes, abundant in both offshore and nearshore habitats. Both juveniles and adults are common on the deep reef.

Beaugregory: The adults, especially, were common in channels cut into islands. Adults and juveniles were most common where calcareous algae (Halimeda sp.), rock caves, and conch shells occurred together. This species is rare below a depth of $7.5 \mathrm{~m}(25 \mathrm{ft}$.$) .$

Yellowtail Damselfish: This species occurred on patch reefs, but the greatest concentrations were found on the reef tops, especially in the Fire coral zone (which is in shallow water). Adults were more common in this zone in slightly deeper water than juveniles.

Sergeant Major: This species occurred frequently around nearshore bridges and seawalls, especially juveniles from $1.8-8.0 \mathrm{~cm}(0.7-3.0 \mathrm{in.})$. Juveniles often remained in schools in restricted areas. Patch reefs support both juveniles and adults, but the maximum abundance occurred on the reef top. Cummings (1968) reported Sergeant Majors in tide pools and also drifting among patches of Sargassum up to $32 \mathrm{~km}$ (20 mi) offshore.

Honey Gregory: This species was not reported inshore; most of ten this species occurred on the outer reefs, primarily on the reef top. Juveniles and adults occurred in equal abundance on the reef tops, except in surge channels where juveniles predominated. This species seems to prefer areas of dense cover and small crevices. 
Yellowtail Reeffish: This species is a deeper water species. Emery (1973) found large concentrations of these fishes at $45 \mathrm{~m}$ (135 ft.) on the deep ledge, and juveniles around sponges in the sand-silt rubble area on the deep reef.

Blue Chromis: This species is abundant on the outer reef top, hovering in the water column $1-2 \mathrm{~m}(3-6 \mathrm{ft}$.) above the reef. Maximum abundance was observed on the deep reef, where both juveniles and adults occurred.

\subsection{Food Habits}

Damselfishes are omnivores (IV), many of them browsers (IV) feeding on algae (although animal material often makes up a large percentage of their diet). Food habits of this family appear to be strongly influenced by the habitat in which the fish lives (Randall 1967), with species in a particular habitat browsing on the most available food sources.

The Threespot damselfish and juvenile Sergeant Major eat primarily algae, although sponges and anemones are also consumed. Juvenile Cocoa damselfish, Beaugregorys, Sergeant Majors, Honey Gregorys, Yellowtail Reeffish, and Blue Chromis rely heavily on plankton, especially copepods. Adult Beaugregorys consume polychaete worms. Juvenile Yellowtail damselfish feed on nematocysts (stinging cells) of Fire coral. Considerable variation occurs among all the above listed diets. More detailed accounts of the food of these fishes are given by Randall (1967) and Emery (1973).

\subsection{Predation}

Randall (1967) and Emery (1973) reported jacks, barracuda, and grouper to be the main predators of damselfishes.

\subsection{Reproduction}

All damselfishes studied to date produce small eggs, individually attached to a hard substrate (choice of substrate is species specific) and cared for by the parent until hatching. It is likely that all damselfishes reproduce in this same manner.

Courtship involves a series of looping motions around a cleared, well guarded nesting area (Cummings 1968). The elliptical eggs are attached to the substrate by a tuft of filaments at the base of the egg. The eggs are carefully guarded day and night by the male for up to 8.5 days (Breder and Rosen 1966). The eggs hatch into minute larvae $0.15 \mathrm{~cm}$ ( $1 / 16 \mathrm{in.)}$ long. A free floating period (3-4 weeks) follows, after which the $f$ ish settle to the bottom as juveniles (Sale 1976). Much of the following data is drawn from Emery's (1973) extensive damselfish study on Alligator Reef, Florida Keys.

Threespot Damselfish: Found nesting on large patch reefs. Although abundant on Fire coral, it has not been observed nesting there.

Cocoa Damselfish: Nests located on the shallow edge of the outer reef. 
Beaugregory: Emery (1973) reported the Beaugregory nesting around islands. Breder and Rosen (1966) noted it often placed its eggs in large, empty conch (Strombus sp.) shells, or utilized undersides of rocks and dead sea fans. Females began breeding at $5.5 \mathrm{~cm}$ ( $2 \mathrm{in.}$ ) in length, and the breeding season extended from June to August (Longley and Hildebrand 1941).

Yellowtail Damselfish: This species nests below the ridge of Fire coral in areas of heavy algal growth. Breeding occurred from June to August (Longley and Hildebrand 1941).

Sergeant Major: Nests are found below the breaker zone in deeper, quieter surge channels on the outer reef. Cummings (1968) reported these fishes aggregate when not involved in reproductive activity. Stark and Davis (1966) observed nesting year round at Alligator Reef, with a peak in the summer. Males were found guarding from 4,000 to 84,000 eggs, the average female contributing 20,000. Clutch size (number of eggs laid) appeared to be limited by substrate (bottom) type.

Honey Gregory: Emery (1973) located nesting Honey Gregorys in the back reef rubble area at Looe Key and Alligator Reef, Florida.

Yellowtail Reeffish: Reproductively active fish were found in August in the Dry Tortugas (Longley and Hildebrand 1941). No other data available.

Blue Chromis: Feddern (pers. commun.) has observed the Blue Chromis with sand nests and nests on hard substrate with low algal cover. Myrberg et al. (1967) studied a closely related species, the Broun Chromis (Chromis multilineata). These fish were reported to defend small areas around rocky ledges and crevices 3-20 m (9-60 ft.) in depth year round. Group aggregations occurred above these territorial areas, and females were observed to individually deposit eggs on nesting areas prepared by the male. In one case, paired spauning without group aggregations was observed. The eggs themselves were microscopic, visible under a low power dissecting microscope.

\subsection{Behavior}

Damselfishes are characteristically extremely territorial (IV) with this territoriality becoming pronounced during the breeding season. However, the Beaugregory and Cocoa damselfish remain extremely territorial year round. Thresher (1976), addressing the territoriality of the Threespot damselfish, showed the size of the territory defended to be related to the type of food eaten by the invader. Protection of the eggs and shelter site are also dependent upon territoriality.

Starck and Davis (1966) observed diurnal feeding in damselfishes. These fishes moved into caves and crevices at night to hide (except males guarding eggs, a duty they perform day and night). Emery (1973) observed the Sergeant Major moving low in the water column as the sun set, schools breaking up, and fishes assuming a dark color phase. Yellowtail damselfish dulled in color and rested on their pelvic fins in crevices. The Blue Chromis also darkens at night, moving into crevices. The Beaugregory, Cocoa and Threespot damselfish, Honey Gregory, and Yellowtail Reeffish did not undergo color changes, but did move back into reef crevices at night. 


\subsection{Local Habitat in the Florida Keys}

During the day, according to Straughan (1973), cardinalfishes hide under ledges, or small coral heads. At night, they emerge into the vater column to feed.

Flamefish: Several investigators have reported the Flamefish to be the most widely distributed of all cardinalfishes in offshore areas (Longley and Hildebrand 1941, Stark and Davis 1966, and Livingston 1971). Livingston (1971) found the daytime habitat to be holes and caves in and around the reef. They occurred singly and in pairs and were often associated with the Long-spined sea urchin. Flamefish have also been reported by Straughan (1963) to occupy inshore sponge beds. At night, the Flamefish can be found out in more open waters feeding, but they remain near the daytime shelter area (Longley and Hildebrand 1941, Livingston 1971).

Barred Cardinalfish: This species is an offshore dweller, located in holes and ledges by day and emerging into the water column at night to feed (Livingston 1971). In the Tortugas, Longley and Hildebrand (1941) found this species to be associated with Finger coral and ledges of other more massive corals.

\subsection{Food Habits}

Cardinalfishes are almost all nocturnal, voracious (greedy eating), carnivores (IV) according to Livingston (1971). They feed primarily on small, swimming crustaceans (shrimp-like animals) in the plankton, small fishes, or small invertebrates (Randall 1967). Migration from the daily shelter spots during nocturnal feeding does not appear to be extensive (Starck and Davis 1966, Livingston 1971).

\subsection{Predation}

Randall (1967) reported an unidentified cardinalfish in the stomach of the Trumpetfish (Aulostomus maculatus) and that the Graysby (Petrometopon cruentatum) consumed the Dusky cardinalfish (Apogon pigmentarius). Longley and Hildebrand (1941) found the Flamefish in the stomachs of two snappers, the Gray snapper (Lut janus griseus) and the Mutton snapper (ㄴ. analis).

\subsection{Reproduction}

Cardinalfishes brood their eggs orally. This unusual technique involves incubation of the eggs in the mouth of the fish, typically the male. Breder and Rosen (1966) reported eggs to be held together in a cluster in the mouth by threads attached to each egg. This is probably an adaptation to insure greater hatching success of the eggs since fish eggs are one of the foods of many tropical fishes, and the cardinalfishes, as a rule, live in rather highly populated areas of the reef.

Pair formation occurs during the winter (Causey, pers, commun.). Breeding peaks from August to November and April to June (Powell 1975, Luckhurst and Luckhurst 1977). Larvae and young seem to remain in the area of hatching (Causey, pers. commun.). 


\subsection{Behavior}

Cardinalfishes are slow, awkward swimmers (Livingston 1971). Perhaps this is related to their reluctance to leave caves and crevices during the day. However, as darkness approaches, the cardinalfishes assume a lighter color phase and move out from their daily shelter site (Starck and Davis, 1966, Livingston 1971).

\section{OPISTOGNATHIDAE: JAWFISHES}

Jawfishes are warm-water fishes, living in vertical burrows that they line with small stones or shells. These fishes can be fascinating in an aquarium because burrows are established and often competition for stones and shells to line the burrow follows. However, because jawfishes are a rather retiring (shy) species, care must be taken to see that they get enough food. Jawfishes have fared well on the aquarium market in the Keys, and the Yellowhead jaufish is frequently collected.

\subsection{Description of the Commercially Valuable Species and its Biogeography}

Jawfishes have large heads without spines or ridges. The face has an extremely steep profile with large eyes, a very large mouth, and an elongate body. In the Bahamas, Bohlke and Chaplin (1968) reported 5 species and Randall (1968) reported 4 species. Starck (1968) found 6 species on Alligator Reef. Only one species will be considered here.

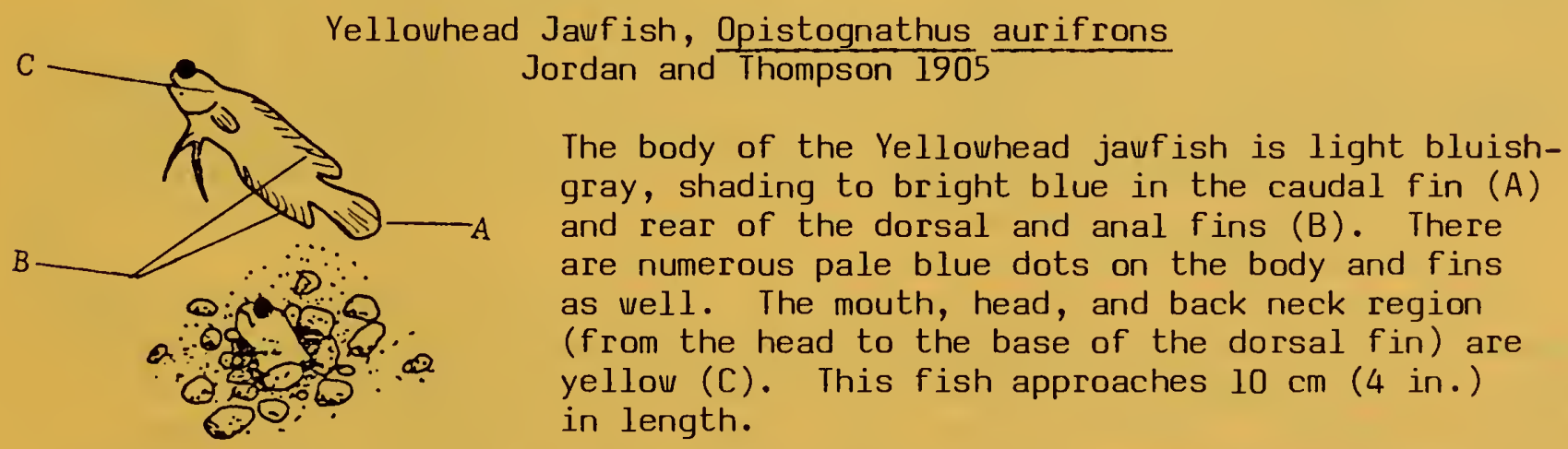

The Yellowhead jawfish is found in the Bahamas, Florida, Cuba, and the Virgin Islands.

\subsection{Local Habitat in the Florida Keys}

Yellowhead jaufish live in colonies. Colin (1970) reported these fishes prefer the seaward side of the reef, usually in depths exceeding $7 \mathrm{~m}(23 \mathrm{ft}$.). The bottom must be soft enough to dig individual burrows. Colin (1970) described three types of burrows, each being 13 - $17 \mathrm{~cm}$ (5-7 in.) deep: 1) under rock burrow; 2) open chamber (which was lined with coral, but not roofed by a rock); and 3) terminal chamber (made of an erosion hole or fracture in a large rock. Ideal habitat, according to Bohlke and Chaplin (1968), is crushed sand over a rock within reach of Turtle grass (Thalassia sp.) and long-spined sea urchins and having a strong current overhead. Jawfishes have been reported to occur as deep as $45 \mathrm{~m}(135 \mathrm{ft}$.$) in the Florida Keys (Bohlke and Chaplin 1968).$ 


\subsection{Food Habits}

Because Yellowhead jawfish feed on plankton (IV) certain restrictions on its feeding are posed. These fishes spend as much as 90\% of their daylight hours in search of the small, widely distributed food items (Colin 1970). Like most plankton feeders, the Yellowhead jawfish detects all of its prey with its eyes. The use of eyesight for picking food particles has resulted in the development of binocular vision (using both eyes at the same time, whereas many fishes utilize monocular vision: the use of one eye to focus on an object). Binocular vision greatly enhances depth perception; however, this vision is restricted to daylight hours (Colin 1970). Bohlke and Thomas (1961) have postulated that the tear-drop shaped eye of jawfish, along with special ligament development, are adapted to provide the sharp eyesight required for a hovering, plankton-feeding existence. The eyes of jawfishes are located so that binocular vision can be obtained while the fish hovers upward in his burrow. Colin (1970) recorded a horizontal feeding range of about $1 \mathrm{~m}(3 \mathrm{ft}$. ) and a vertical range of $1.5 \mathrm{~m}$ ( $5 \mathrm{ft}$.$) from the burrow.$

Randall (1967) reported that copepods were the primary food of the Yellowhead jawfish (85\% of stomach contents) with shrimp larvae also being eaten.

\subsection{Predation}

Colin (1970, 1971) reported on reactions of Yellowhead jawfish to other fishes swimming near, over, and around their burrous. The Nassau grouper (Epinephelus striatus), Yellowtail snapper (Ocyurus chrysurus) and Margate (Haemulon album) caused the most severe retreat reactions by the jawfishes. Randall (1967) reported 2 jawfish in the stomach of the Southern Stingray (Dasystis americana). Colin (1971) speculated on several species as potential predators: the 3 mentioned above, plus Sand tilefish (Malacanthus plumieri), Slippery Dick (Halichoeres bivitatus), and the Yellowhead wrasse (․․ garnoti).

\subsection{Reproduction}

Jawfishes spawn from spring through late summer (Colin 1970). Mayo (pers. commun. as cited in Colin 1970) described a short larval life (1 month) after which the young (which are unusually large upon hatching) settled to a burrowing habitat. The larvae and young remain near the area of hatching (Causey, pers. commun.). Females produce 1500 eggs, which are orally brooded by the male (Colin 1970).

Leong (1967) described pair formation and spawning of the Yellowhead jawfish. Pair formation involved a male leading a female into a prepared burrow. This was accomplished by the male swimming high in the water and performing attractive movements (displays) for the female. If successful, the male attracted the female out of her burrow and together they would descend into a third burrow (the male tail first and the female head first). This pair formation occurred long before spawning, and once performed, the two formed a pair, permitting one another into their respective burrows. A pair will defend a burrow area (each pair defends 2 or more burrows) against a third intruder during breeding season. Sex partners are permitted to enter one anothers' territory and burrow without fighting. 
Before spawning, the male enters the female's burrow more frequently, but neither remain together long. Courtship displays are similar to pair formation with the male attracting the female into his burrow. After spawning, the female departs. The male incubates the eggs orally, rotating them for aeration, and depositing them on the burrow bottom during feeding periods. During this incubation period, the female is banned from the male's burrow, but the male is permitted in the burrow of the female.

\subsection{Behavior}

Although jaufishes live individually in burrows, they are a social species in that 10-20 burrows comprise a colony (Colin 1970). Jawfishes spend most of the daylight hours hovering just above the burrow, but at night, they retreat into it, and shut it with a rock (Colin 1971). The burrow is lined with rocks, and the large canine teeth (III) of the jawfish have been hypothesized to aid in carrying these rocks (Colin 1970). Stealing of rocks and other suitable buriow liners are common in the colony.

Longley and Hildebrand (1941) described the threat response of jawfishes, "On the approach of danger, they settle down tailfirst, and in an emergency, they dart in headfirst." Jawfishes were reported as territorial, but Colin (1971) found them not to be as forceful as damselfishes, defending themselves only against smaller or similar sized fishes.

\section{SCIAENIDAE: DRUMS AND CROAKERS}

Drums and croakers are so named because of their ability to produce sound with the muscles of the swim bladder (IX), this organ acting as a resonance chamber. The reef dwelling drums discussed below are impressive, especially juveniles, whose first dorsal $f$ in (I) is elevated and may extend beyond the caudal fin. These fishes (especially the Jackknife and Spotted drum) present several problems for the hobbyist: 1) they require plenty of space; 2) they are finicky eaters; and 3) they seem prone to skin diseases (de Graaf 1973). However, the time spent in maintaining these fishes is well worth the investment if their beauty is considered.

\subsection{Description of the Commercially Valuable Species and Their Biogeography}

This family of fishes is characterized by two distinct dorsal fins (I) barely connected at the base. The first dorsal is elevated. This may deter predators since a large mouth would be required to swallow the fish whole. Bohlke and Chaplin (1968), and Randall (1968) reported 4 species in the Bahamas. Starck (1968) reported 7 species on Alligator Reef. Three species are considered here. Species descriptions are adapted from Bohlke and Chaplin (1968) and Randall (1968). 

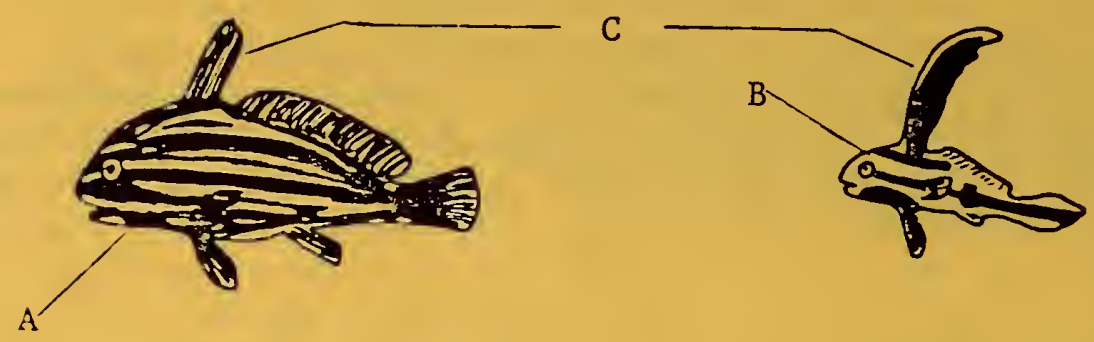

The High Hat has a series of dark brown and white stripes, the dark stripes alternating in width from a narrow to broad $(A)$. Young fish have fewer stripes (B). The first dorsal $f$ in is elevated (C), especially in juveniles, in which it is elongated as vell.

The High Hat occurs from Bermuda and North Carolina south to Rio de Janeiro, and in the Gulf of Mexico.

\section{Jackknife Fish, Equetus lanceolatus Linnaeus 1758}
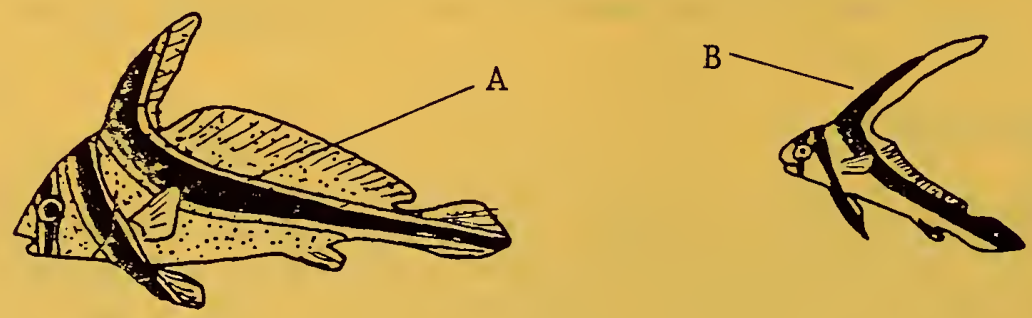

The Jackknife fish is gray with 3 white-edged dark brown to black bands (A). The juveniles are impressive with elongated first dorsal fins (B) (Goodson 1976). This species reaches $23 \mathrm{~cm}$ (9 in.) in length. Brazil.

The Jackknife fish has been reported from Bermuda and South Carolina to Spotted Drum, Equetus punctatus Bloch and Schneider 1801
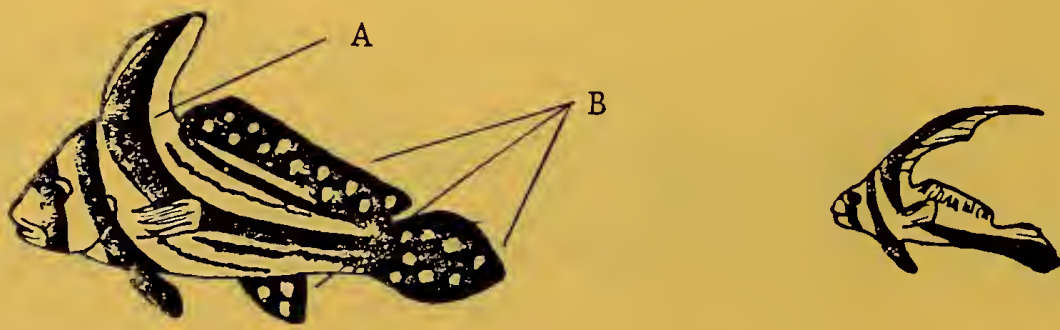

The Spotted drum is grayish-white with several brown to black bars on the body $(A)$. The second dorsal $f$ in, anal $f$ in, and caudal $f$ in are dark brown with white spots (B). Juveniles have no spotting. This species is the largest drum discussed, with adults reaching $26 \mathrm{~cm}$ (10.5 in.) in length.

The Spotted drum occurs from southern Florida to the West Indies. 
During the day, these fish hide in small groups under ledges or coral heads (Randall 1968). High Hats are often reported around rocks, sand, Turtle grass, coral, or combinations of these (Straughan 1973). The High Hat is almost always present on shallow reefs surrounded by seagrasses (Straughan 1973). High Hats are the hardiest of the 3 species, and are often found inshore, whereas the Jackknife fish and Spotted drum are restricted to outer reef waters.

\subsection{Food Habits}

All three species feed primarily at night. Nocturnal migration from caves and crevices into the water column to feed is well documented (Longley and Hildebrand 1941, Starck and Davis 1966, Randall 1967). Starck and Davis (1966) reported nocturnal feeding to be solitary. Randall (1967) reported the High Hat feeds primarily on shrimps and shrimp larvae, as well as other crustaceans. The Jackknife fish also feeds on shrimps and polychaete worms. The Spotted drum has the most varied diet, feeding on crabs, unidentified crustaceans, shrimps, and hermit crabs (Randall 1967).

\subsection{Predation}

No information is available in the literature concerning predation on any species of the genus Equetus. Consumption of the High Hat by the Ringed anemone (Bartholomea annulata) in an aquarium has been observed by John Stevely.

\subsection{Reproduction}

Goodson (1976) reported members of the genus Equetus to be permanent residents on the reef, unlike other members of the Sciaenid family, that have to move to estuarine vaters to spawn. Consequently, this has extended the range of the genus Equetus to the West Indies, Central and South America. Longley and Hildebrand (1941) found reproductively active female Jackknife fish from June through August. Munro (1973) reported ripe female Spotted drums in April, July, and September. Breder and Rosen (1966) reported croakers have pelagic eggs. Moe (pers. commun.) has raised both the Jackknife fish and High Hat and reported a 3 week larval stage.

\subsection{Behavior}

As mentioned, drums are active at night. According to Starck and Davis (1966) they often appear in groups of up to 20 during the day, but tend to feed solitarily at night. Beebe and Tee Van (1933) pointed out a-permanence in choice of habitat, i.e., individuals located in the same crevice week after week.

\section{BLENNIIDAE: BLENNIES,}

Blennies are small, blunted-headed, bottom fishes (Randall 1968). Beebe and Tee Van (1933) described this family, "They seem to be the most intelligent Bermuda fish by their actions and appearance. This is enhanced by hand and foot-like use of the pelvic fins, and conspicuous intellitent looking eyes." 
Blennies are lively and inquisitive inhabitants of home aquaria, and require small hiding places (de Graaf 1973).

\subsection{Description of the Commercially Valuable Species and Their Biogeography}

The blenny family is easily identified by the continuous dorsal $f$ in (I), which is not broken into two parts as we have seen in most fish families. The family Blennidae derive their name "comb tooth" blennies from their close-set teeth (III) resembling a comb (Bohlke and Chaplin 1968). Eight species are found in the Bahamas (Bohlke and Chaplin 1968) and Starck (1968) reported 5 species on Alligator reef. Three species are collected in the Keys. The following descriptions are adapted from Bohlke and Chaplin (1968) and Randall (1968).

\section{Molly Miller, Blennius cristatus Linnaeus 1758}

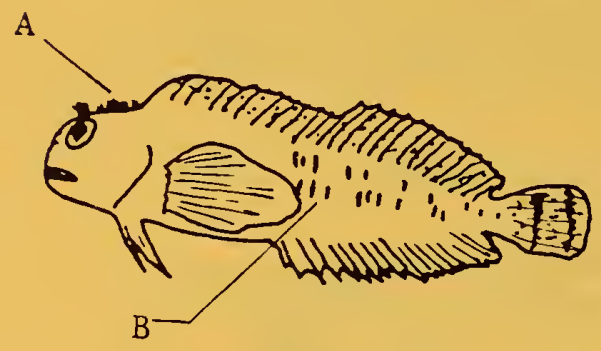

The Molly Miller is distinctive with its band of cirri (I) on the head (A). Bohlke and Chaplin (1968) reported these appendages to be helpful for both "the systematist and presumably for other individuals of the blenny species" to recognize one another. Coloration varies from yellowishgray on the back, and bluish-gray to almost yellow coloration on the side. There are numerous small brown spots, some of which form stripes and bars (B). The paired fins are yellow. The Molly Miller has been reported to reach $7 \mathrm{~cm}$ (3 in.) in length.

This species is found on both sides of the Atlantic, on the western side from Bermuda, the Bahamas, and the Florida Keys to Brazil.

Redlip Blenny, Ophioblennius atlanticus Cuvier and Valenciennes 1836

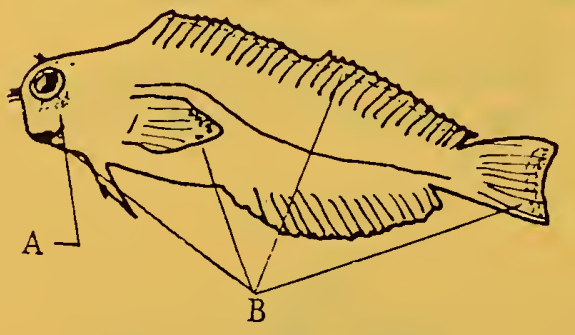

The adult Redlip blenny is dark, while progressively younger juveniles are lighter in coloration. There is a dark spot beneath the eye (A), and there are red areas on the edge of the dorsal fin, lips, and parts of the caudal and pectoral fins (B). Because of different coloration in the juveniles, and different body shape (torpedo-like), the juveniles vere once considered a separate species (Bohlke and Chaplin 1968). The Redlip blenny reaches $12 \mathrm{~cm}$ ( 5 in.) in length.

This species occurs from Bermuda and South Carolina to the Lesser Antilles, and eastern shores of Central America.

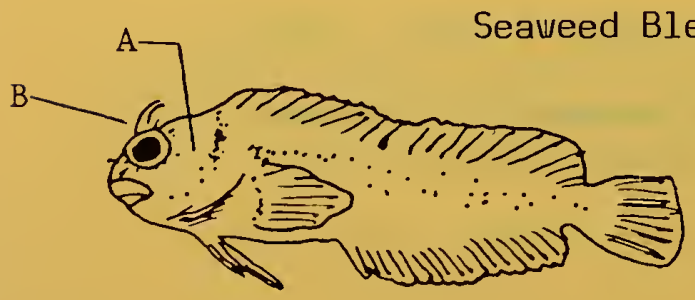

The Seaweed blenny has a golden head (A) with brown from the eyes to the caudal fin. Considerable variation in the shading occurs. This species does not have a series of cirri on the head, simply one outgrowth (B). The Seaweed blenny rarely exceeds $7 \mathrm{~cm}$ ( 3 in.) in length. 
Seaveed blennies occur from North Carolina to Brazil, including the Gulf of Mexico.

\subsection{Local Habitat in the Florida Keys}

Blennies may be found in tidepools, on rocky slopes, under boulders, in or under shells, in grass beds, and around corals (Bohlke and Chaplin 1968). Typically bottom dwelling fishes, they live in close association with rocks and coral, sitting on the surface until danger approaches, then hiding inside crevices and holes.

Molly Miller: Straughan (1973) reported this species to skip around the coral reef, living in crevices in the coral. Randall (1968) and Smith (1974) found them to be common in rocky areas near shore and in tidepools.

Redlip Blenny: Bohlke and Chaplin (1968) reported this species to prefer shallow water on coral and rock bottoms, the deepest recorded species taken at $8 \mathrm{~m}(25 \mathrm{ft}$.). The senior author has observed this species on inshore coral heads and on shallow outer reef areas. Causey (pers. commun.) reported many blennies on bridge pilings and in channels during the summer of 1977 following the January and February cold spells.

Seaveed Blenny: Longley and Hildebrand (1941) reported this species to occur on rocky tracts, and in dead coral, of ten making its home in the holes of boring bivalves (clams). They also found them under a single rock in sand or a single coral head in Turtle grass if shelter was provided.

\subsection{Food Habits}

Blennies are bottom feeders, eating primarily algae and detritus (decomposing material) (Randall 1967; Overstreet, pers. commun. as cited in Smith 1974).

\subsection{Predation}

The only report of predation in the literature is of a Trumpetfish consuming an unidentified blenniid (Randall 1967).

\subsection{Reproduction}

The anal $f$ in (I) has been used to sex blennies (Smith 1974). The first anal $f$ in spine in females is barely visible, the second is obvious. In males, these two spines are flattened as pads. Losey (1969, as cited in Smith 1974) pointed out that this pad may be a source of secretions of pheromones (chemical attractants), aiding in synchronizing spauning. The anal $\mathrm{f}$ in in males develops fleshy lateral extensions during breeding periods. Wickler (1957, as cited in Smith 1974) hypothesized these extensions to be useful in cleaning. the eggs. It appears that blennies produce demersal, eggs which are guarded in cavities by the male (Randall 1968, Smith 1974). 
Goodson (1976) described blennies as sharp-eyed and active. Gibson (1969, as cited in Smith 1974) described the Molly Miller sitting up on rocks, propped up on its pectoral fins, "The Molly Miller is able to maintain position on the bottom, often in a vertical position in spite of turbulence and wave action. Since it and most other blennies have no swim bladder (IX), it does not have to counteract buoyancy. This alone, however, is insufficient to account for its observed tenacity (ability to hold firmly) in clinging to rocks." The bracing action of pectoral and pelvic fins aids in this support, but the split anal fins (I) act as hooks to hold the fish in place (Gibson 1969, as cited in Smith 1974). When approached, the blennies will quickly retreat and stare at intruders with the large eyes mounted high on the head (for excellent vision). Starck and Davis (1966) reported no sightings of blennies after dark.

\section{LABRIDAE: WRASSES}

Wrasses are a family of predominantly cigar-shaped fishes, usually brightly colored, and often displaying several color phases. These fishes are often the most numerous on the reef, and are perhaps, the most diversified family in body form and size (Randall 1967). These fishes do vell in aquaria, but require a sand bottom as they frequently bury themselves at night.

\subsection{Description of the Commercially Valuable Species and Their Biogeography}

Wrasses have small to medium mouths, thick lips, and curved canine teeth (III) that protrude, causing a buck tooth appearance. They use their pectoral fins for swimming. Bohlke and Chaplin (1968) and Randall (1968) reported 15 species in the Bahamas, while Starck (1968) reported 19 species on Alligator Reef. Three species will be discussed. The following descriptions are adapted from Bohlke and Chaplin (1968) and Randall (1968).

Bluehead, Thalassoma bifasciatum Bloch 1791

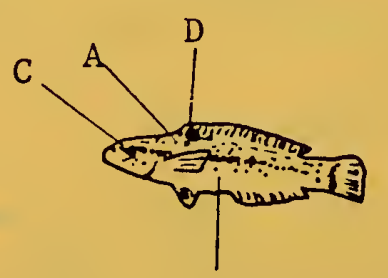

B

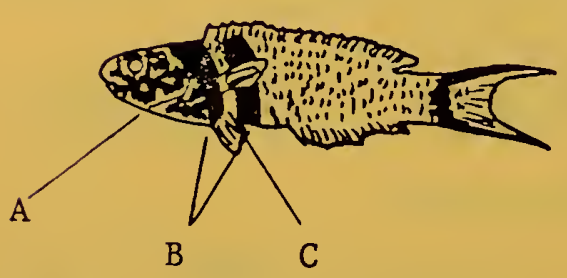

The Bluehead displays several color phases during its life. The most distinct are the juvenile (yellow) phase and the adult (blue) phase. In the yellow phase, the upper body and head are bright yellow (A) with the lower half white (B). There is a large, orange-broun blotch around the eye (C) and a dark spot in the dorsal fin (D). In the blue phase, the head is blue (A) and the body green; these two colors being separated by broad, verticle, black bands (B) with a bluishwhite band between (C). The blue phase fish are always adult males, making up about 4\% of the population. Other color phases are juvenile and adult fishes of both sexes. The Bluehead reaches $15 \mathrm{~cm}$ (6 in.) in length. 
The Bluehead occurs from Bermuda, the Florida Keys, the southern Gulf of Mexico, and the Bahamas, south to Columbia.

\section{Spanish Hogfish, Bodianus rufus Linnaeus 1758}

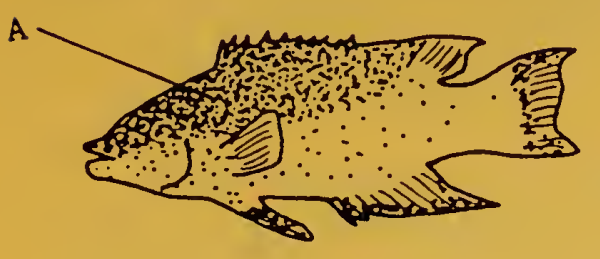

The upper body is bluish- to plum-colored (A) (In juveniles this color may cover the front half of the fish); the remainder is yellow. The jaus of the young fish develop a golden-orange color which turns reddish with age. This species reaches $38 \mathrm{~cm}$ (15 in.) in length.

The Spanish hogfish occurs in Bermuda, Southern Florida, the Gulf of Mexico, and the Bahamas.

Spotfin Hogfish, Bodianus pulchellus Poey 1860

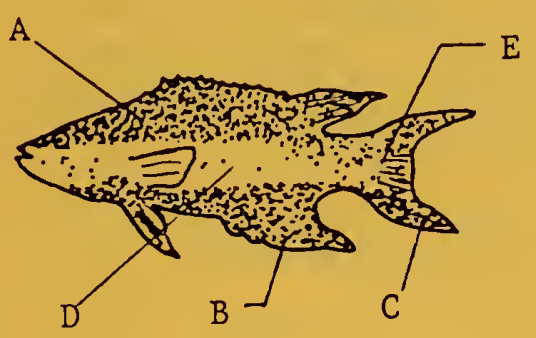

Juvenile Spotfin hogfish are yellow, with the front half of the dorsal fin black. With age, red areas develop on the upper two-thirds of the body (A), lower sides of the body (B), and caudal fin (C). The lower half of the head and central body (D) of adults are white, and the upper half of the caudal peduncle, dorsal $f$ in, and caudal fin (E) are yellow. This species reaches $23 \mathrm{~cm}$ (9 in.) in length.

The Spotfin hogfish has been reported from South Carolina to Southern Florida and the West Indies.

\subsection{Local Habitat in the Florida Keys}

Bluehead: This species is most numerous on rocky or coral bottoms (Feddern 1965). Goodson (1976) reported it in most offshore habitats including reefs, rocky flats, reef sand, and sea grasses.

Spanish Hogfish: Feddern (1963) reported this species on coral reefs and rocky areas, nearshore and offshore, as vell as most rocky areas where the water is flowing or turbulent.

Spotfin Hogfish: This is a deep water species. Feddern (1963) and Colin (1975) reported it around coral and rocks in depths of at least $16 \mathrm{~m}$ (50 ft.). Spotfin hogfish prefer vertical rock surfaces to level reefs and occur commonly on the deep reef and ledges.

\subsection{Food Habits}

Compacted sand and rubble bottoms seem to be preferred by feeding vrasses (Hiatt and Strasburg 1960). Hobson (1975) has observed wrasses hovering near the feeding jaws of larger fishes that stir up the sea bottom, especially herbivores (IV). The wrasses snap up small fishes and crustaceans as they are driven from hiding. Bohlke and Chaplin (1968) and Randall (1968) mentioned plankton as a food source for many wrasses. Randall (1968) found that juveniles of several species are parasite pickers (IV). 
Bluehead: Blueheads, like the cardinal fishes, are voracious (hearty appetite) carnivores (IV), but unlike the cardinal, feed during the day. Randall (1967) observed Blueheads swimming near the bottom, feeding on invertebrates with hard parts (molluscs, crustaceans). These prey items were easily crushed by well developed pharyngeal teeth (II). Apparently little effort is made to eject these hard parts as they are present in the stomach contents. The canine teeth (II), located at the mouth opening, can be used to remove gastropods (snail-like molluscs) and other adhering animals.

Yellow phase blueheads, especially juveniles, have been reported to be parasite pickers (Longley and Hildebrand 1941, Collette and Talbert 1972). However, parasites picked from other fishes may constitute a very small portion of the total diet (Longley and Hildebrand 1941). Collette and Talbot (1972) mentioned the abundance of Blueheads on the reef, pointing out yellow phase juveniles swarming in loose aggregations picking at small benthic and planktonic animals.

Spanish Hogfish: The parasite picking behavior of young Spanish hogfish was noted by Limbaugh (1961), Randall (1962) and Eibl-Eibesfeldt (1965 as cited in Randall 1967). Adults have been reported to feed on crabs, brittle stars, urchins, and molluscs (Schroeder and Starck 1964, Randall 1967).

Spotfin Hogfish: No data was available on the specific food items of this species, although Randall (1968) reported that juveniles are probably parasite pickers (IV).

\subsection{Predation}

Bluehead: Randall (1965) reported a hamlet (Hypoplectrus sp.) eating a Bluehead, and de Sylva (pers. commun. as cited in Feddern 1965) reported Roughtail stingray (Dasyatis centroura) consumed Blueheads. Randall (1967) found the following species to have Blueheads in their stomachs: Trumpetfish, Yellowfin grouper (Mycteroperca venenosa), and the Soapfish (Rypticus saponaceus).

Spanish Hogfish: Randall (1967) reported the Spanish hogfish in the stomach of the Schoolmaster snapper (Lutjanus apodus). Limbaugh (1961) reported the Trumpetfish and Yellowfin grouper to also consume this species.

Spotfin Hogfish: There were no reports of predation on this species.

\subsection{Reproduction}

Bluehead: The Bluehead exhibits two types of spawning: aggregate and paired spawning (Feddern 1965). Randall and Randall (1963, as cited in Feddern 1965) described the aggregate and paired spauning as follows:

"The fish (yellow or white phase) usually concentrate their activity over prominent rocks or heads of coral. As many as 80 or more begin to swim more rapidly in one direction and then another. As with parrotfishes, there is a sudden upward or diagonally upward movement which resulted in the fish being a maximum of about $2 \mathrm{ft}$. above the rest of the group. A small cloud of white could often be seen, indicating release of sperm. 
Rarely were the large Blueheads present in the milling aggregation of the yellow phase fish, and then they mostly chased individual yellow fish.

On only two occasions was spawning by blue phase and yellow phase females observed. After a very short chase, the female fish darted upward with the male Bluehead and they spauned."

Spauning occurs throughout the year, except in September (Feddern 1965). Longley and Hildebrand (1941) noted a peak in spawning during August. Goodson (1976) reported blue phase males spauned 40 - 100 times/day, with each spauning period lasting about 1 week. Examination of $r$ ipe females by Feddern (1965) showed between 800 - 3,000 eggs/spawn. Males and females over $30 \mathrm{~mm}$ (1.2 in.) participated in the spaun. De Boer, et. al. (1973) reported many large blue phase $f$ ish participating in paired spauning to have reached senescence (menapause) and to be sterile. Feddern (1965) also found some large blue and yellow phase fishes to be sterile.

Little is known concerning reproduction of the Spanish and Spotf in hogfish, although Moe (pers. commun.) has reported that male Spanish hogfish are twice the size of females and that small eggs are laid during the summer.

\subsection{Behavior}

Most wrasses are active during the day, burying themselves in sand at night (Feddern 1965, Randall 1968). Schroeder and Starck (1966) observed the Spanish hogfish hiding in coral crevices at night. Adults tend toward schooling, especially Blueheads, while juveniles are solitary (Feddern 1965, De Boer, et. al. 1973).

\section{GOBIIDAE: GOBIES}

The goby family has more species (over 1,000) than any other family of marine fishes (Colin 1975). Every general coral reef area in the western Atlantic, except Bermuda, has at least one species of Gobiosoma (Colin 1975). Gobies living in tropical Atlantic waters are rather unique in that they display, according to Colin (1975) "unusual ecological and behavioral adaptations." Several goby species are parasite pickers (IV) and set up cleaning stations which many larger fish visit to have parasites picked from their mouths and gills. The Neon goby is the only cleaning species commonly collected in the Florida Keys and, therefore, is the only species considered here. The Neon goby is a popular aquarium fish. Few fishes have better adaptations to tank living. The Neon goby is small, brightly colored, easy to feed, and is one of only a few species to breed successfully in captivity. 


\subsection{Description of the Commercially Valuable Species and its Biogeography}

Most gobies have their pelvic fins joined to form a sucking disc, allowing these fish to cling to corals, sponges, or rocks. (Randall 1967). This family is often confused with the blenny family (Bleniidae), but can be differentiated by a continuous dorsal fin in the blenny family, and two dorsal fins in the goby family (I). Of the twelve species of the genus Gobiosoma that occur in the entire tropical Atlantic, seven are closely associated with corals, and the other five with sponges. Six of these twelve species are parasite pickers (IV) (Colin 1975). Bohlke and Chaplin (1968) reported forty-four goby species (entire family, including the genus Gobiosoma), in the Bahamas. Starck (1968) reported twenty-seven species on Alligator Reef.

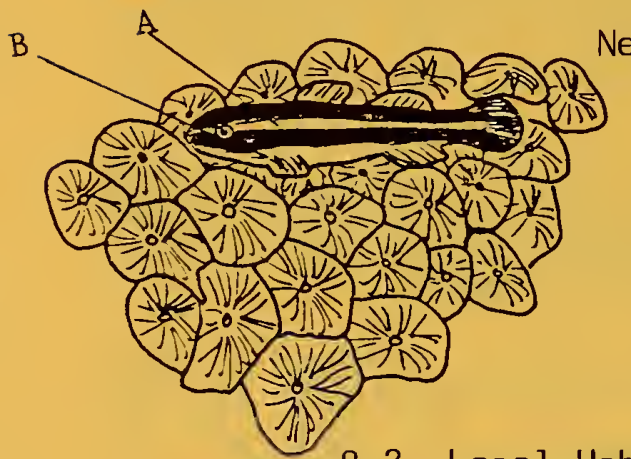

Neon Goby, Gobiosoma oceanops Jordan

\subsection{Local Habitat in the Florida Keys}

The Neon goby has been reported in waters from $1-40 \mathrm{~m}(3-120 \mathrm{ft}$.$) in$ depth. This species (all ages from newly metamorphosed to adults) is frequently found in association with corals or rocks. Colin (1975) reported the Star coral and Large Star coral (Montastrea cavernosa) to be the coral species most frequently having the Neon goby on their surfaces. The Neon goby was found singly. or in groups of up to $30 \mathrm{fish} / \mathrm{coral}$ head. Colin (1976) reported, "populations of Gobiosoma sp. in limited localities do show some, often considerable variation over periods on the order of the life span ( 1 уг.) of individual fishes."

The fact that gobies can associate with corals is interesting. Corals are carnivores, possessing cells within their tissues known as nematocysts or stinging cells. These stinging cells release harpoon-like projectiles which stab and kill prey. Barnes (1968) reported two methods of discharge for these deadly stinging cells - one chemical, and the other physical. It appears that the Neon goby possesses some chemical that prevents the discharge of these stinging cells (Colin 1975).

\subsection{Food Habits}

Neon gobies are parasite pickers (IV), frequently termed "cleaners" (Darcy, et. al. 1974, Colin 1975). Colin (1975) reported no competitive behavior among cleaners, and all ages of fishes participated in cleaning. Using a snipping motion of the teeth, parasites are removed from the host ( $f$ ish being cleaned). The entire body of the host may be inspected, including the gills and inside the mouth. 


\subsection{Predation}

Several biologists have hypothesized cleaning fishes and invertebrates to be free from predation because of their important cleaning function (Limbaugh 1961, Randall 1965). DeLisle (1969 as cited in Colin 1975) performed some experiments to test this hypothesis. One involved releasing anesthetized gobies into the water column over a reef and observing the reactions of the fishes in the area to the goby sinking. No predation was observed, although some fishes did "pose" to be cleaned.

\subsection{Reproduction}

The Neon goby is one of only a few species of marine tropicals to have bred in captivity. Walker (1977) has made available his technique to the home aquarist, and this technique is summarized here. Neon gobies are "sexable, small, fairly easy to spaun, and produce large, active young." The sexes can be distinguished by the male's genital papilla (pointed organ just forward of the anal $f$ in), the female's ovipositer (in the same location) which is short, blunt, and almost unnoticeable. The Neon goby is a "secretive spauner" (Moe 1975) and a shell or flower pot must be provided for the Neon goby to place its eggs under. Gobies spawn naturally in the winter and early spring (Feddern 1967, Colin 1975). These natural conditions can be simulated in the home aquarium by maintaining temperatures between $70^{\circ}-75^{\circ} \mathrm{F}$ and providing 7-9 hrs. of light/day. Females average 250 eggs/spawn, but larger frmales may carry 300 - 500 eggs (Colin 1975; Moe 1975). Larval Neon gobies changed into juveniles in $12-14$ days (Colin 1975; Moe 1975).

\subsection{Behavior}

Neon gobies can be found on the sides of corals, both day and night, although at night, with the coral polyps expanded to feed, the gobies become difficult to see (Schroeder and Starck 1964). "Clẻaning stations" are established by the Neon goby (most of ten on the upper surface of brain corals) and larger fishes come and may even wait in line to be cleaned.

\section{DIVERSITY OF TROPICAL CORAL REEF FISH COMMUNITIES}

The tremendous diversity of life living in association with coral reefs is a characteristic of coral reef communities (a community being an association of interacting populations) which is recognized by even the most casual observer. The 30 species described here represent only a fraction of the total number of fishes present. For example, Starck (1968) reported 389 species of fishes on Alligator Reef, and Bohnsack (pers. commun.) more than 200 species on Looe Key.

As would be expected, many biologists have pondered the question of speciation, and why certain habitats have a more diverse fauna than others. As would also be expected, considerable disagreement has arisen over whose theories are right or wrong. A thorough discussion of the evolution of modern biological thought concerning community diversity is beyond the scope of the present paper. However, for those interested, a brief description of some of the newly emerging theories specifically concerning tropical reef $f$ ish diversity is included here. It must be recognized, however, that the following discussion 
simply presents some interesting ideas and preliminary findings, and does not represent either proven theories, or a comprehensive review of all aspects of speciation.

Smith-and Tyler (1972, 1973a,b, 1975) were among the first biologists to discuss diversity in coral reef communities. They hypothesized that fish specialized to minimize competition for food and space, two critical resources on the reef. Study of tropical bird communities let McArthur (1972) and Cody (1973) to conclude that diversity could be explained in terms of resource portioning (division of food and space) allowing more species in an area before serious competition results. However, more, recent research (Sale 1974, 1975, 1976, 1977) has revealed reef fishes with similar space and food requirements coexisting (living together and sharing the same resources), not specializing and dividing up the resources.

Several biologists have shown reef $f$ ishes to specialize into large habitats, such as reef crest, reef flat, etc.; but upon examination, reef fishes with very similar or identical food and space requirements coexist successfully within these large habitats (Sale 1974, 1975; Sale and Dybdahl 1975). Root (1967) has termed these groups of species utilizing the same resources a "guild". Sale $(1974,1975)$ has demonstrated the existance of such a guild between 4 species of damselfishes on the Australian Great Barrier Reef, and suggested several others.

Existance of these guilds contradicts theories which suggest that high species diversity is the result of extreme specialization. Thus, although reef fishes specialize broadly into habitats, within habitats it appears that there is neither specialization with respect to food and space, and several species of fishes with highly specialized requirements of ten coexist with other species showing similar adaptations (Sale 1977).

Smith and Tyler (1972), Goldman and Talbot (1976), and Sale (1977) have all found living space to be the resource most limiting the numbers of fishes on reefs. Sale (1977) has also found living space to be unpredictable. Grouth of coral, wave action, silting, and shifting of sand and rubble can alter habitat. suitable coral outcroppings or other required habitat is often widely and somewhat randomly distrïbuted. Large storms, also unpredictable, can drastically alter the reef structure. Predators (which are unpredictable in time and space) affect fishes that live in a habitat. Sale (1977) has hypothesized this unpredictability of living space (habitat) to be important to reef fishes. He states, "In a situation in which the supply of living space is limited and vacant living space is unpredictable in time and space, the production of numerous offspring scattered widely in space and time appears to be the only satisfactory way of getting some offspring successfully to living sites. Similarly, successful offspring should stay put."

Numerous studies on reproduction in coral reef fishes have been undertaken in the last few years (Munro, et. al. 1973; Powell 1975; Sale and Dubdahl 1975; and Luckhurst and Luckhurst 1977). All observed seasonal peaks in reproduction 
but noted at least some year round spawning in most species. Little data is available on frequency of spawning, although it does appear to be frequent, and numerous larvae are produced each spawn. Sale (1977) has suggested that the extended breeding seasons and frequent spawning of reef $f$ ishes are strong evidence that life cycles do occur in response to unpredictability of space in the reef environment.

Reef fish larvae scatter widely in space. Most reef fishes produce eggs which are found on or near the bottom, but some have pelagic larvae. Studies of larval dispersal and length of larval life need attention and should be considered by biologists interested in reef fishes. Little is known of what happens to fish larvae after hatching, until they settle on the reef as juveniles.

Studies by Greenburg (1947), Braddock (1949), Phillips (1971), Frey and Miller (1972) and Myrburg (1972) indicate that territorial battles are usually decided in favor of the original resident. Thus, offspring successful in finding suitable living space should stay put. Once living space is gained, survival is greatly enhanced. Reese (1964) observed limited movement by the majority of reef fishes. Bardach (1958) and Springer and McErlean (1962), in their tagging studies, observed limited movement in groupers, snappers, angelfishes, butterflyfishes, and surgeonfishes.

Sale (1977) has described a number of mechanisms used by reef fishes to cope with the unpredictable nature of available living space:

1) dispersing numerous pelagic (open ocean) larvae widely both in space and time so. as to maximize chances of getting some offspring to suitable space;

2) having requirements for space that remain general enough for there to be some chance of finding a suitable site;

3) remaining in a site, once found, for extended periods or throughout adult life.

Sale (1977) also noted that species of fishes in a guild are competing in a "lottery for living space in which larvae are the tickets, and the first arrival at a vacant site wins that site. The lottery operates within the habitat and at the levels of the individual fish." Vacant sites are generated unpredictably, and are immediately refilled. Because the types and numbers of larvae in a given area are unpredictable as well, it is unlikely that one species will dominate a habitat. "So long as all species of a guild win some of the time and in some places, they will continue to put larvae into the plankton and hense into the lottery for new sites" (Sale 1977). 
Completion of this project would not have been possible without the assistance of the following people. We especially thank Jim Bohnsack, Billy Causey, Henry Feddern, and Martin Moe, for their review of the rough draft. Their advice and comments were invaluable. We also thank Bill Becker, Stan Becker, Chris Combs, Irene Hooper, Thomas Murray, Leigh Taylor, Art Weiner, and the entire Sea Camp/Newfound Harbor Marine Institute (Big Pine Key, FL) staff. The assistance of Julia Josiek (Librarian, Southeast Fisheries Center, National Marine Fisheries Service, Miami) was invaluable. Considerable thanks also to the entire Monroe County Cooperative Extension Service staff, especially Nancy Brewer and Mary Ann Sasnett for their labors in preparing the manuscript, and Robin Kulik for assisting in gathering the necessary research literature.

Fiscal support for this undertaking was provided by the Monroe County Board of Commissioners, which made available Comprehensive Employment Act funds for the Monroe County Marine Resource Inventory. Heartfelt thanks are extended to the Florida Cooperative Extension Service, Marine Advisory Program for its direction and guidance in completion of this project and to the National Marine Fisheries Service and the Southeast Fisheries Center for providing publication funding. 


\subsection{Literature Cited}

AIKEN, K.A.

1975. The biology, ecology, exploitation and management of Caribbean reef fishes. Part V. The biology, ecology, and bionomics of Caribbean reef fishes: Chaetodontidae (butterfly and angelfishes). Sci. Rep. of O.D.A./U.W.I. Fish Ecol. Res. Proj., 1969-1973. Zool. Dept. U. W. Indies, No. 3:57 p.

ALBRECHT, $H$.

1969. Behavior of four species of Atlantic damselfishes from Columbia, South America. Z. Tierpsycol. 26:662-676.

ALEVISON, W.S., and M.G. BROOKS.

1975. The comparative structure of two western Atlantic reef fish assemblages. Bul1. Mar. Sci. 25(4):482-490.

BARDACH, J.E.

1958. On the movements of certain Bermuda reef fishes. Ecol. $39(1): 139-146$.

BARNES, R.D.

1968. Invertebrate Zoology. W. B. Saunders Co., Phila., PA. 743 p. BEEBE, W., and J. TEE-VAN.

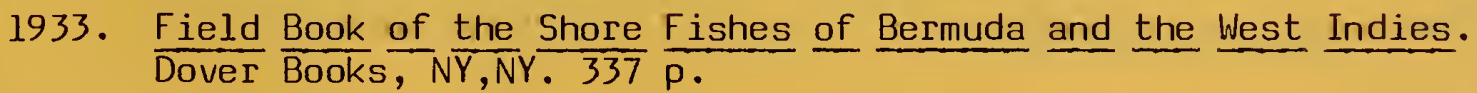
BOHLKE, J.E., and C.G.G. CHAPLIN.

1968. Fishes of the Bahamas and Adjacent Tropical Waters. Livingston Pub. Co., Wynnewood, PA. $771 \mathrm{P}$.

BOHLKE, J.E., and P. THOMAS.

1961. Notes on the west Atlantic jawfishes, Opisthognathus aurifrons, 0 . lonchurus, and Gnathypops bermudezi. Bull. Mar. Sci. Gulf Carib.11(4): $503-5 \overline{16 .}$

BRADDOCK, J.C.

1949. The effect of prior residence upon dominance in the fish Platypoccilus maculatus. Physiol. Zool. 22:161-169.

BREEDER, C. M., Jr., and D.E. ROSEN.

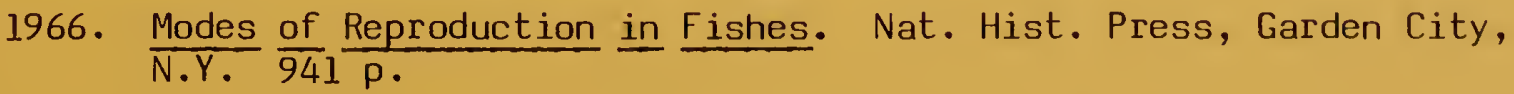


BURGESS, W.E.

1974. Evidence for the elevation to family status of the angelfishes (Pomacanthidae), previously considered to be a subfamily of the butterflyfish family (Chaetodontidae). Pac. Sci. 28(1):57-71.

CODY, N.L.

1973. Competition and the Structure of Bird Communities. Princeton U. Press. 318 p.

COLIN, P.L.

1970. The behavior and ecology of the yellowhead jawfish, Opistognathus aurifrons. A thesis of the Univ. of Miami for Master of Science, 41 p. Rosensteil School of Marine and Atmospheric Science, 4600 Rickenbacker Causeway, Miami, Florida 33149.

1971. Interspecific relationships of the yellowhead jaufish, Opistognathus aurifrons. Copeia 3:469-473.

1974. Observation and collection of deep-reef fishes off the coasts of Jamaica and British Honduras. Mar. Biol. 24:29-38.

1975. The Neon Gobies. T.F.H. Pub., Inc. Neptune City, N.J. 304 p. COLLETTE, B.B., and F.H. TALBOT.

1972. Activity patterns of coral reef fishes with emphasis on nocturnaldiurnal changeover. Nat. Mul. L.A. Co. Sci. Bull. 14:98.

COTT, H.B.

1940. Adaptive Coloration in Animals. Oxford Univ. Press, N.Y. 508 p. CUMMINGS, W.C.

1968. Reproductive habits of the Seageant Major, Abudefduf saxatilis, with comparative notes on four other damselfishes in the Bahama Islands. A thesis of the Univ. of Miami for PhD, $158 \mathrm{p}$. Rosensteil School of Marine and Atmospheric Science, 4600 Rickenbacker Causeway, Miami, Florida 33149.

DARCY,G.H., E. MAISEL, and J.C. OGDEN.

1974. Cleaning preferences of the gobies Gobiosoma evelynae and G. prochilos and the juvenile urasse Thalassoma bifasciatum. Copeia 1974 (2):375-379. 
DeBOER, B., D. HOEGERIVERF, I. KRISTENSEN, and J. POST.

1973. Antillian Fish Guide. Carib. Mar. Biol. Inst., Curacao, Netherlands Antilles. $110 \mathrm{p}$.

de GRAFFE, $F$.

1973. Marine Aquarium Guide. The Pet Library Ltd., Sterenco Corp. Harrison, N.J., 284 p.

EMERY, A.R.

1973. Comparative ecology and functional osteology of fourteen species of damselfish at Alligator Reef, Florida Keys. Bull. Mar. Sci. 23(3):649-770.

FEDDERN, H.A.

1963. Color pattern changes during growth of Bodianus pulchellus

B. rufus (Pisces:Labridae). Bull. Mar. Sci. Gulf Carib.

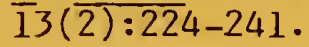

1965. The spawning, growth, and general behavior of the Bluehead urasse. Bull. Mar. Sci. 15(4):896-941.

1967. Larval development of the Neon goby, Elacatinus oceanops, in Florida. Bull. Mar. Sci. 17:367-375.

1968. Systematics and ecology of western Atlantic angelfishes, family Chaetodontidae, with an analysis of hybridization in Holacanthus. A thesis of the Univ. of Miami for PhD., $211 \mathrm{p}$. Rosensteil School of Marine and Atmospheric Science, 4600 Rickenbacker Causeway, Miami, Florida 33149.

FEDER, H.M.

1966. Cleaning symbiosis in marine environments. IN: S.M. Henry (editor) Symbiosis 1:327-380. Academic Press, N.Y.

FREY, D.R., and R.J.MILLER.

1972. The establishment of dominance relationships in the blue gourami, Trichogastor trichopterus (Dallas). Behavior 42:1-62.

GINSBURG, R.N.

1956. Environmental relationships of grain size and constituent particles in some south Florida carbonate sediments. Bull. Amer. Petrol. Geog. 40:2384-2427. 
GOLDMAN, B., and F.H. TALBOT.

1976. Aspects of the ecology of coral reef fishes, Ch. 4. , 193 p.

GOODSON, G.

1976. Fishes of the Atlantic Coast. Marquest Colorguide Books, California, 204 p.

GREENBERG, B.

1947. Some relationships between territory, social hierarchy, and leadership in the green sunfish (Lepomus cyarellus).

HOBSON, E.S.

1969. Comments on certain recent generalizations regarding cleaning symbiosis in fishes. Pac. Sci. 23:35-39.

LAGLER, K.E., J.E. BARDACH, and R.R. MILLER.

1962. Ichthyology. John Wiley and Sons, Inc., N.Y., N.Y., 497 P. LEONG, D.

1967. Breeding and territorial behavior in Opistognathus aurifrons. Die Naturwissenschaften 54(4):97.

LIMBAUGH, C.

1961. Cleaning symbiosis. Sci. Amer. 205(2):42-49.

LIVINGSTON, R.J.

1971. Circadian rhythms in the respiration of eight species of cardinalfishes. Mar. Biol. 9:253-266.

LONGLEY, W.H., and S.F. HILDEBRAND.

1941. Systematic catalogue of the fishes of Tortugas, Fla. with observations on color, habits, local distribution. Paps. Tortugas Lab., Carnegie Inst. Wash. Publ. 34(535): 331 p.

LUCKHURST, B.E., and K. LUCKHURST.

1977. Recruitment patterns of coral reef fishes on the fringing reef of Curacao, Netherlands Antilles. Can. J. Zool. 55:681-689. 
MacARTHUR, R.H.

1972. Geographical Ecology: Patterns in the distribution of species. Harper and Row, N.Y., 269 p.

MOE, M.A.

1972. Movement and migration of south Florida fishes. Fla. Dept. Nat. Res. Tech. Ser. No. 69:1-25.

1975. Propagating the Atlantic Neon goby. Mar. Aq.

1977. Inside the egg of an angelfish. Mar. Aq.

MUNRO, J.L., V.C. GAUT, R. THOMPSON, and P.H.REESON.

1973. The spawning seasons of Caribbean reef fishes. J. Fish. Biol. $5(1): 69-84$.

MYRBERG, A.A. , Jr.

1972. Social dominance and territoriality in the bicolor damselfish. Behavior 41:207-231.

MYRBURG, A.A., D. BRADLEY, and A.R. EMERY.

1967. Field observations on reproduction of the damselfish, Chromis multilineata, with additional notes on general behavior. Copeia 1967(4):819-827.

NAGELKERKEN, W.P.

1974. On the occurrence of fishes in relation to corals in Curacao. Stud. Fauna Cruacao, No. 147:118-141.

PHILLIPS, R.R.

1971. The relationship between social behavior and the use of space in the benthic fish Chasmides bosquianus. II. The effect of prior residency on social and enclosure behavior. 7. Tierpsy. Chol. $24: 389-408$.

POWELL, H.

1975. Abundance, seasonality, distribution, and aspects of the ecology of some larval fishes off Barbados. A thesis of McGill Univ. for PhD. McGill Univ., Montreal, Canada. 227 p. 
RANDALL, J.E.

1965. Grazing effect on sea grasses by herbivorous reef fishes in the West Indies. Ecol. 46(3):255-260.

1967. Food habits of reef fishes of the West Indies. Stud. Trop. Ocean. Univ. of Miami 5:665-847.

1968. Caribbean Reef Fishes. T.F.H. Pub. Co., Inc., Neptune, N.J., $318 \mathrm{p}$.

RANDALL, J.E., and W.D. HARTMAN.

1968. Sponge-feeding fishes of the West Indies. Mar. Biol. 1:216-225. RANDALL, J.E., and H.A. RANDALL.

1968. The spauning and early development of the Atlantic parrotfish, Sparisoma rubripinne, with notes on other Scarid and Labrid fishes. Zool. N.Y. 48(5):49-60.

REESE, E.S.

1964. Duration of residence by coral reef fishes on "home" reefs. Copeia 1973:145-149.

ROOT, R.B.

1967. The niche exploitation pattern of the blue gray gnatcatcher. Ecol. Monogr. 37:317-350.

SALE, P.F.

1974. Mechanisms of coexistance in a guild of territorial fishes at Heron Island. Proc. Sec. Ind. Coral Reef Symp. 1977, 1:193-206.

1975. Patterns of use of space in a guild of territorial reef fishes. Mar. Biol. 29:89-97.

1976. Reef fish lottery. Nat. Hist. 85(2):61-65.

1977. Maintenance of high diversity in coral reef fish communities. Amer. Natur. III (978):337-359.

SALE, P.F., and R. DYBDAHL.

1975. Determinants of community structure for coral reef fishes in an experimental habitat. Ecol. 56(6):1343-1355.

SANDERS, H.L.

1968. Marine benthic diversity, a comparative study. Amer. Nat. 102: $243-282$. 
SCHROEDER, R., and W.A. STARCK.

1964. Photographing the night creatures of Alligator Reef. Natl. Geog. $125(1): 128-154$.

SCOTTON, L., and D. de SYLVIA.

1972. Fish Babies. Sea Frontiers 4:194-201.

SMITH, R.L.

1974. On the biology of Blennius cristatus with special reference to anal fin morphology. Bull. Mar. Sci. 24(3):595-605.

SMITH, C.L., and J.C. TYLER.

1972. Space resource sharing in a coral reef-fish community. Nat. Mus. L.A. Co. Sci. Bull. 14:125.

1973a. Direct observations of resource sharing in coral reef $f$ ish. Helgolander wiss. Meeresunters 24:264-275.

1973b. Population ecology of a Bahamian suprabenthic shore fish assemblage. Am. Mus. Novit. 2528:1-38.

1975. Succession and stability in fish communities of dome-shaped patch reefs in the West Indies. Am. Mus. Novit. 2572:1-18.

SPRINGER, V.C., and A.J. McERLEAN.

1962. A study of the behavior of some tagged South Florida_coral reef fishes. Amer. Midl. Nat. 67(2):386-397.

STARCK, W.A.

1968. A list of fishes of Alligator Reef, Florida with comments on the nature of Florida reef $\mathrm{fish}$ fauna. Undersea Biol. $1(1): 5-40$.

STARCK, W.A., and W.P. DAVIS.

1966. Night habits of fishes of Alligator Reef, Florida. Ichthyologica $66: 313-356$.

STRAUGHAN, R.L.

1973. The Marine Collector's Guide. A.S. Barnes and Co., Cranbury, 
THRESHER, R.E.

1976. Field analysis of the territoriality of the Threespot damselfish. Copeia $1976(2): 266-276$.

WALKER, S.

1977. Walker successfully spawns five species. Mar. Hobbyist News $5(9): 1-4$.

WILSON, E.0.

1975. Sociobiology. $\frac{\text { The New }}{\text { Press, Cambridge, Mass., } 697 \mathrm{p} \text {. }}$ Belknap Press, Harvard Univ.

10.2 Additional References

BAKUS, G.J.

1967. The feeding habits of fishes and primary production at Eniwetok, Marshall Islands. Micronesica 3:135-149.

BARDACH, J.E.

1959. The summer standing crop of fish on a shallow Bermuda reef. Limnol. Oceanogr . 4:77-85.

BARDACH, J.E., and D.W. MENZEL.

1956. Field and laboratory observations on the growth of some Bermuda reef fisheries. Proc. Gulf Carib. Fish. Instit., 9th Session: $106-113$.

BOHLKE, J.E.

1955. On the Bahamian fishes of the family Opisthognathidae. Notulae Naturae 281:1-6.

1967. A new sexually dimorphic jawfish (Opisthognathidae) from the Bahamas. Notulae Naturae 407:1-12.

BOHLKE, J.E., and C.C.G. CHAPLIN.

1957. Oral incubation in Bahaman jawfishes Opisthognathus whitehursti, and $\underline{0}$. maxillosus. Sci. 125(3243):353.

BOHLKE, J.E., and J.E. RANDALL.

1968. A key to the shallow-water west Atlantic cardinalfishes (Apogonidae) with descriptions of five new species. Proc. Acad. Nat. Sci. Phil. 120:175-206. 
BRADBURY, R.H.

1977. Independent lies and holistic truths: towards a theory of coral reef communities. Third Int. Coral Reef Symp., Miami, p. 1-7.

BRIGGS, J.C.

1958. A list of Florida fishes and their distribution. Bull. Fla. St. Mus. 2(8):223-319.

BRINEY, F.J.

1939. Spawning habits and developments of beaugregory. Copeia 1939: $185-188$.

CIARDELLI, A.

1967. The anatomy of the feeding mechanism and food habits of Microspathodon chrysurus. Bull. Mar. Sci. 17(4):845-883.

COLIN, P.L., and J.B. HEISNER.

1973. Associations of two species of cardinalfishes with sea anemones in the West Indies. Bull. Mar. Sci. 23:521-524.

CONNELL, J.H., and E. ORIAS.

1964. The ecological regulation of species diversity. Amer. Natr. 98: $399-414$.

DAVIS, W.P., and R.S. BIRDSONG.

1973. Coral reef fishes which forage in the water column. Helgolander wiss Meeresunters 24:292-306.

EARLE, S.A.

1972. The influence of herbivores on the marine plants of Great Lameshur Bay, with an annotated list of plants. In: Results of the Tektite Program: Ecology of coral reef fishes. Nat. Mus. L.A. Co. Sci. Bull. 14:17.

EHRLICH, P.R.

1975. The population biology of coral reef fishes. Ann. Rev. Ecol. Sys. $6: 211-247$.

EIGENMANN, C.H., and J.E. HORNING.

1887. A review of Chaetodontidae of North America. Ann. N.Y. Acad. Sci. $4(7-8): 1-18$. 
FISCHELSON, L.

1970. Behavior and ecology of a population of Abudefduf saxatilis at Eliat (Red Sea). Anim. Behav. 18:225-237.

FOWLER, H.W.

1919. Notes on tropical American fishes. Proc. Acad. Nat. Sci. Philad. $71: 128-155$.

GILBERT, C.R.

1972. Characteristics of western Atlantic reef-fish fauna. Quart. J.

Fla. Acad. Sci. 35(2-3):130-144.

GUDGER, E.W.

1929. On the morphology, coloration, and behavior of seventy teleostean fishes of Tortugas, Florida. Pap. Tortugas Lab. 26(5):149-204.

HENSHALL, J.A.

1894. Notes on fishes collected in Florida in 1892. Bull. U.S. Fish. Comm. $14: 209-221$.

1889. Report upon a collection of fishes made in S. Florida during 1889. Bull. U.S. Fish. Comm. 9:371-389.

HENSLEY, D., and G.B. SMITH.

1977. Additional data on the pomacentrid fish, Chromis scotti. Copeia $1977(2): 391-393$.

HIATT, R.W., and D.W. STRASBURG.

1960. Ecological relationships of the fish fauna on coral reefs of the Marshall Islands. Ecol. Monogr. 30:65-127.

HOBSON, E.S.

1965. Diurnal-nocturnal activity of some inshore fishes in the Gulf of California. Copeia 1965:291-302.

1968. Coloration and activity of fishes, day and night. Undervater Natur. Winter :6-11.

1972. Activity of Hawaiian reef fishes during the evening and morning transitions between daylight and darkness. Fish. Bull. U.S. 70: $715-740$.

1973. Diel feeding migrations in tropical reef fishes. Helgolander wiss. Meeresunter 24:261-270. 
1975. Feeding patterns among tropical reef fishes. Am. Sci., JulyAugust:382-392.

JORDAN, D.S.

1884. The fishes of the Florida Keys. Bull. U.S. Fish. Comm . 4:77-80.

1885. List of fishes collected at Key West, Florida, with notes and descriptions. Proc. U.S. Nat. Mus. 7:103-150.

KLOPFER, P.H.

1959. Environmental determinants of faunal diversity. Amer. Natur. 93: 337-342.

LOSEY, G.S.

1972. The ecological importance of cleaning symbiosis. Copeia 1972: 820-833.

MacARTHUR, R.H.

1965. Patterns of species diversity. Biol. Rev. 40:410-533.

MARSHALL, N.B.

1966. The Life of Fishes. World Pub. Co., Cleveland, Oh., $402 \mathrm{p}$. MENZEL, D.W.

1959. Utilization of algae for growth by the angelfish Holacanthus bermudensis. J. du Conseil 24(2):308-313.

MYRBERG, A.A., Jr .

1972. Social dominance and territoriality in the bicolor damselfish. Behavior 41:207-231.

MYRBERG, A.A., Jr., and R.E. THRESHER.

1974. Interspecific aggression and its relevance to the concept of territoriality in reef fishes. Am. Zool. 14:81-96.

OPPENHEIMER, J.R.

1970. Mouthbreeding in fishes. Anim. Behav. 18:493-503.

PIANKA, E.R.

1966. Latitudinal gradients in species diversity: A review of concepts. Am. Nat. 100:33-46. 
RANDALL, J.E., and H.A. RANDALL.

1960. Examples of mimicry and protecitive resemblance in tropical marine fishes. Bull. Mar. Sci. Gulf Carib. 10(4):444-480.

REESE, E.S.

1964. Duration of residence by coral reef fishes on "home" reefs. Copeia 1973:145-149.

REID, G.K.

1954. An ecological study of the Gulf of Mexico fishes, in the vicinity of Cedar Key, Florida. Bull. Mar. Sci. Gulf Carib. 4(1):1-94.

RISK, M.J.

1972. Fish diversity on a coral reef in the Virgin Islands. Atoll Res. Bull. 153:1-6.

RIVAS, L.R.

1960. The fishes of the genus Pomacentrus in Florida and the western Bahamas. Quart. J. Fla. Acad. Sci. 23(2):130-162.

ROBINS, C.R.

1971. Distributional patterns of fishes from coastal and shelf water of the tropical western Atlantic. In: Symposium on investigations and resources of the Caribbean and adjacent regions. F.A.0. Fish. Rep. $71(2): 249-255$.

ROUGHGARDEN, J.

1974. Species packing and the competition function with illustrations from coral reef fish. Theor. Pop. Biol. 5:163-186.

SALE, P.F.

1972. Effect of cover on agonistic behavior of a reef fish: A possible spacing mechanism. Ecol. 53:753-758.

SMITH, C.L., E.H. ATZ, and J.C. TYLER.

1971. Aspects of oral brooding in the cardinalfish Cheilodipterus affinis. Am. Mus. Novit. 1456:1-11.

TALBOT, F.H., and B. GOLDMAN.

1972. A preliminary report on the diversity and feeding relationships of the reef fishes of One Tree Island, Great Barrier reef system. In: Proc. Symp. Corals and Coral Reefs 1969:425-442. India. 
VALENTI, R.J.

1972. Embryology of the Neon goby. Copeia 1972(3):477-482.

WALLS, J.G.

1975. Fishes of the Northern Gulf of Mexico. T.F.H. Pub. Co., Inc., 


\section{Definitions of General Terminology}

(adapted from Ricklefs, 1973)

Adaptation - a genetically determined characteristic that helps an animal or plant cope with its environment.

Carrying Capacity - the number of individuals that the resources of a habitat can support.

Coexistence - the occurrence of two or more species in the same habitat; usually applied to potentially competing species.

Community - an association of interacting populations of plants or animals.

Competition - use or defense of a resource by one individual that reduces the availability of that resource to other individuals.

Diversity - a measure of the variety of species in a community that takes into account the relative abundance of each species.

Generalist - a species with broad food or habitat preferences, or both.

Habitat - a place where an animal or plant normally lives, of ten it is characterized by a dominant plant form or physical characteristic (i.e., stream habitat, forest habitat).

Home Range - that area which an animal learns thoroughly and habitually patrols.

Microhabitat - the particular parts of the habitat that an individual encounters frequently in the course of its activities.

Niche - all the components of the environment with which the animal or plant interacts.

Recruitment - addition by reproduction of new individuals to a population. Specialists - a species with specific food or habitat preferences, or both. Stability - inborn capacity of any system to resist change. 
Appendix A continued: Terminology Referenced in the Paper by Roman Numeral (Ricklefs 1973).

I. Fins:

Fins are supported by spines (A) or rays (B).

Median fins - fins in a line with the middle axis of a fish. below: $C, D$, and $E$.

Paired fins - sets of two fins on a fish. below: $F$ and $G$.

Cirri - flaps of skin, of ten on head. below: $\mathrm{H}$.

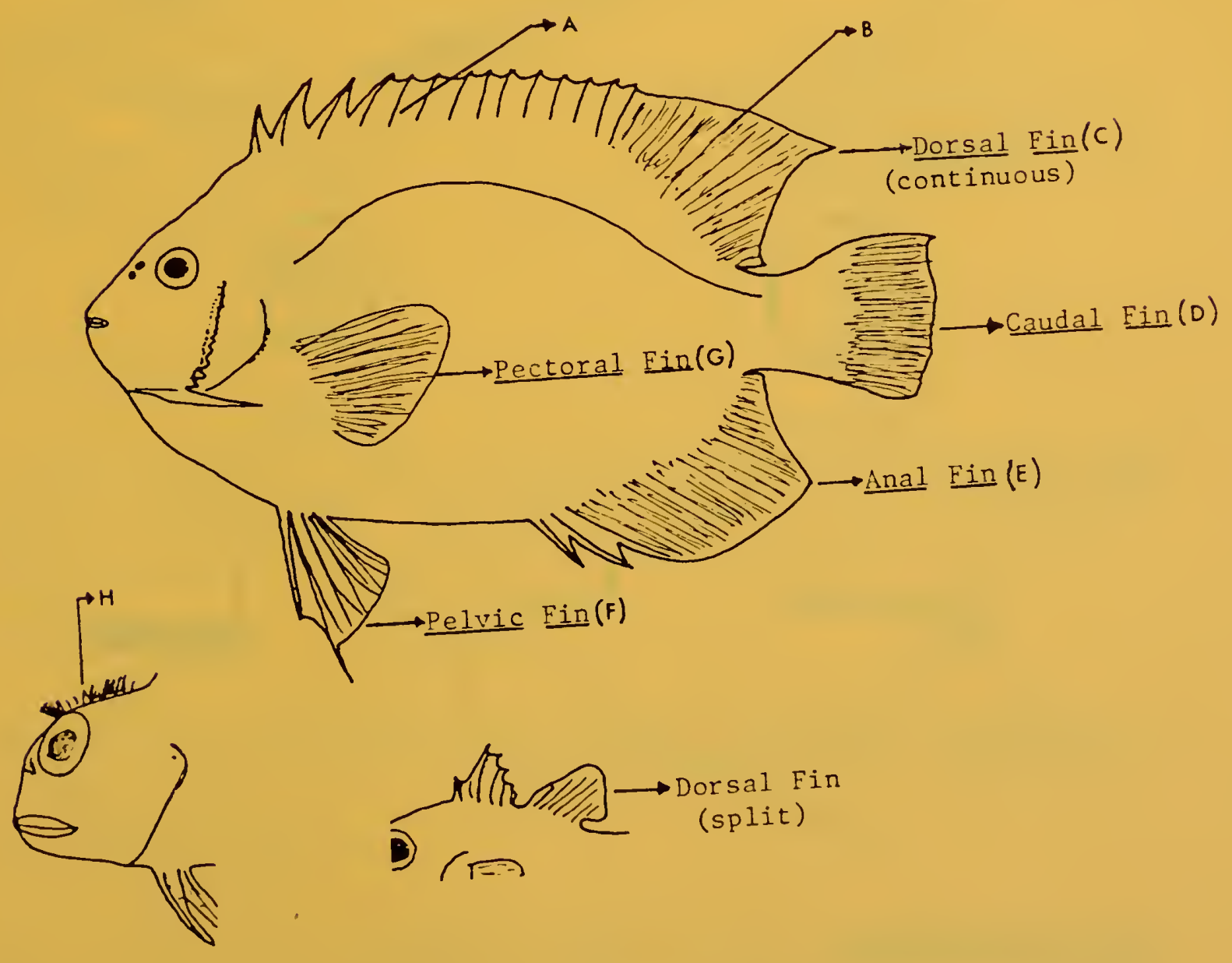


Appendix A continued:

Caudal fin types:

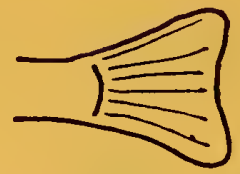

Truncate

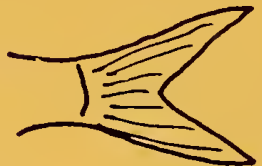

Forked
Slow Swimming Fishes

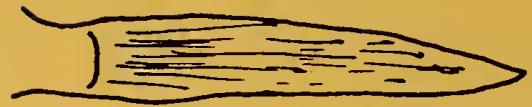

Lanceolate

Fast Swimming Fishes

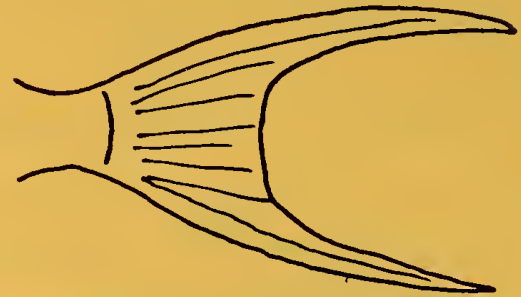

Lunate

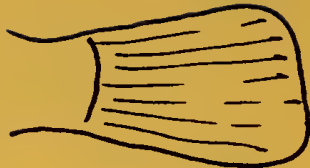

Rounded

II. Scale Types:

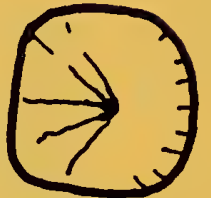

Cycloid

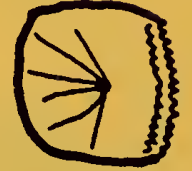

Ctenoid

III. Teeth:

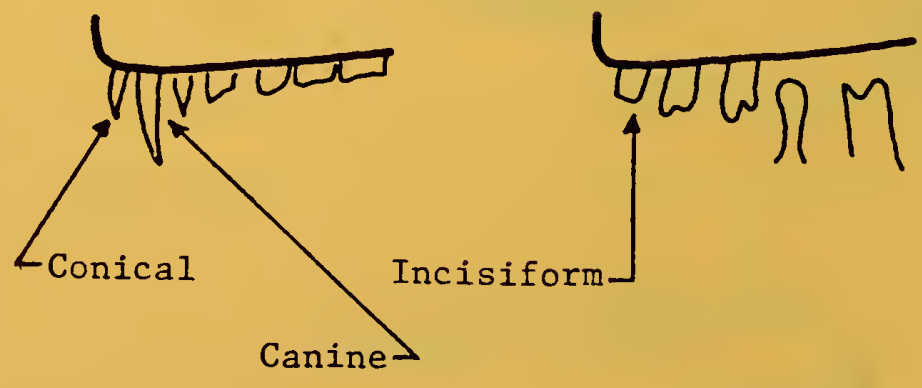

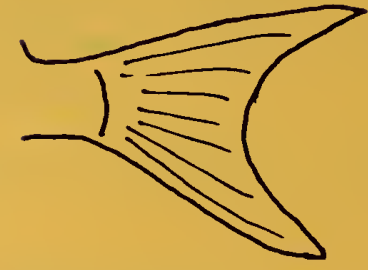

Emarginate

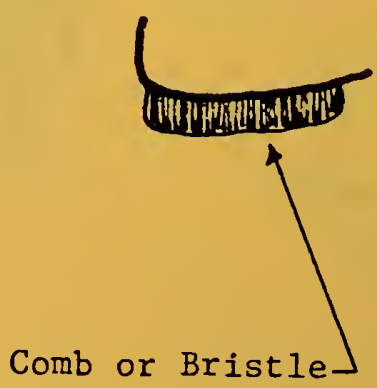

IV. Feeding Types:

Carnivores - animal (meat) eaters.

Herbivores - plant eaters.

Omnivores - eats both animals and plants.

Planktivores - plankton eaters. 
Appendix A continued:

Piscivores - fish eaters.

Parasite Pickers - eat parasites from other fishes.

Browsers - nibblers, grazers.

V. Sponge Structure:

The skeleton of sponges is made up of spicules or fibers, or sometimes both. Spicules can be calcareous (made up of calcium carbonate) or siliceous (made up of silica). The fibers are made of a protein material. Spicules appear in a number of forms (below) and are used to determine the identification of many sponges.

Spicules

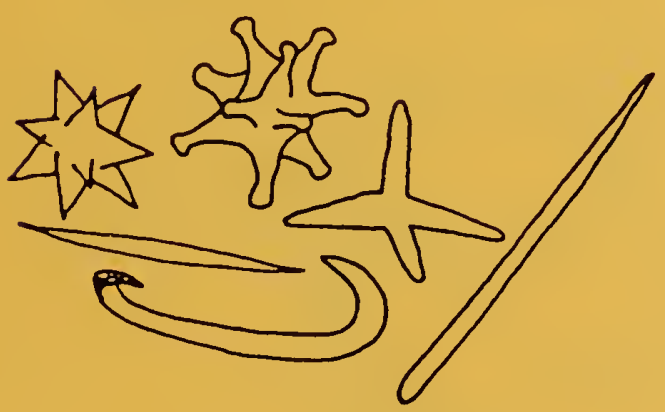

Spongin

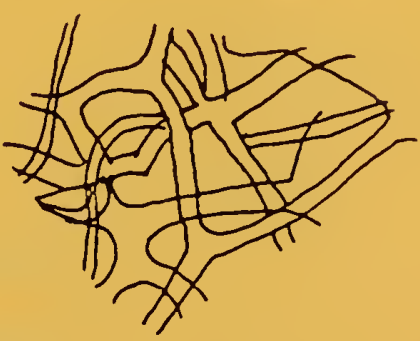

\section{Territoriality:}

A territory is an area occupied more or less exclusively by an animal or group of animals by means of repulsion through overt defense (without hiding) or advertisement. Some reasons for territoriality include protection of a shelter area, nesting area, food source, mate, or just a swimming area.

\section{Nematocysts:}

Nematocysts are specialized stinging cells characteristic of the animal grouping called coelenterates (corals, sea anemones, and jellyfish). A long harpoon-like thread is released by the cell either from physical or chemical stimuli.

\section{Lateral Line:}

The lateral line is a series of pores in a fish's scales forming what appears to be a line on the fish. These holes are involved in pressure sensing, allowing water to contact the skin. The lateral line of an angelfish is drawn in the drawning under Section I. 
Appendix A. continued:

IX. Swim Bladder:

The swim bladder is a gas filled sac found in true fishes just under the backbone. It functions in hydrostatic balance (floating, or adjusting buoyancy with depth), as an auxiliary breathing organ, in sound production, and in sound reception.

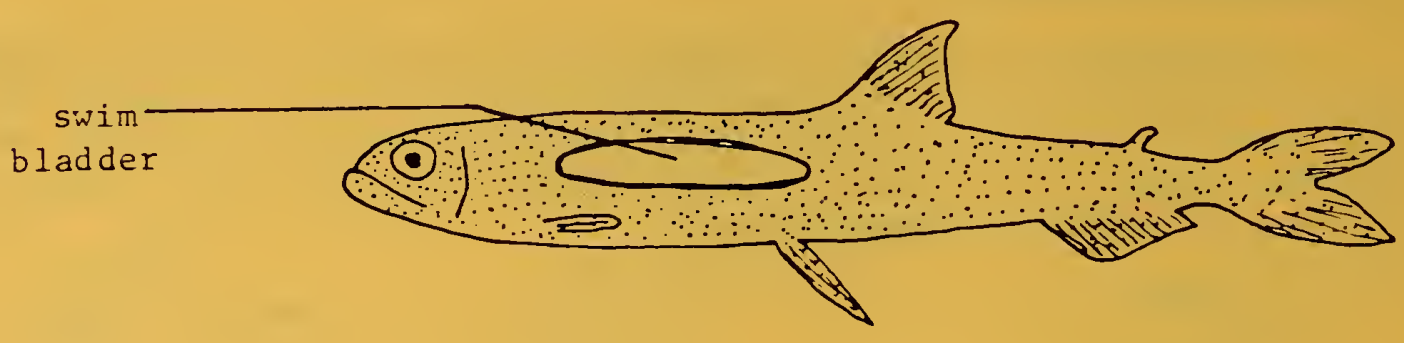




\section{APPENDIX B}

MAPS:

Map 1. The Western Atlantic Ocean (range for most aquarium reef fishes discusses) (adapted from Goodson 1976).

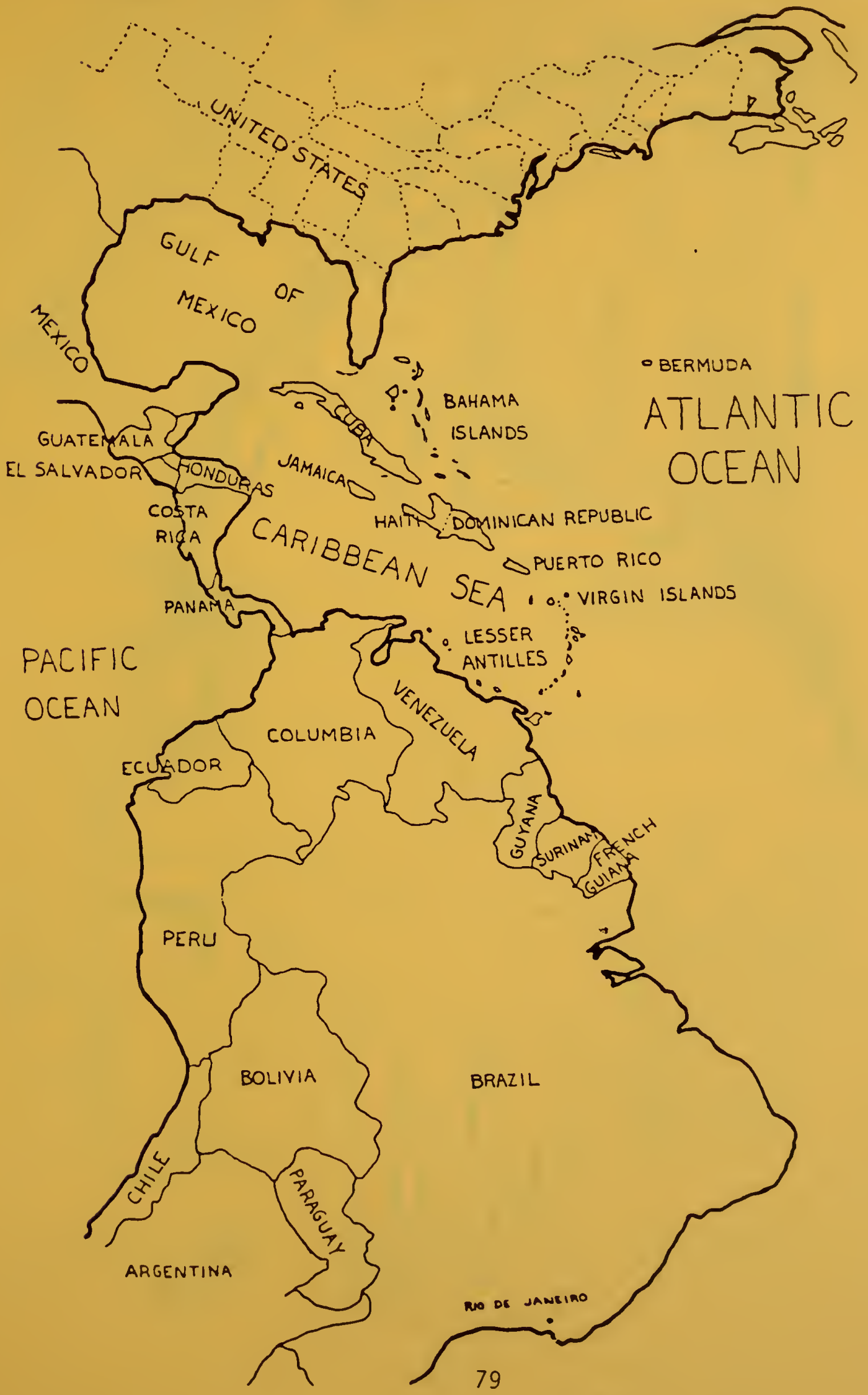


Appendix B continued:

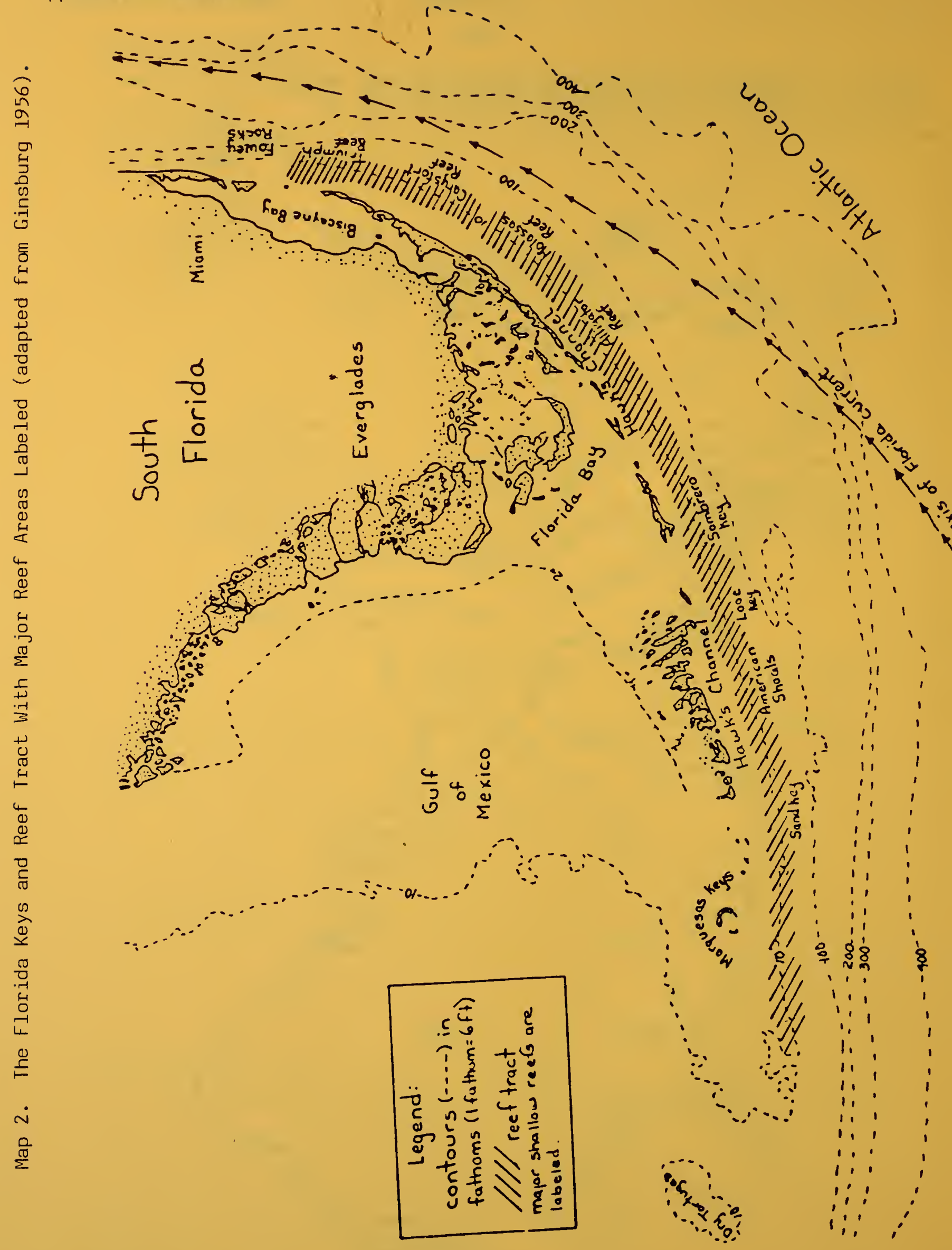


APPENDIX C

Common Plants and Animals

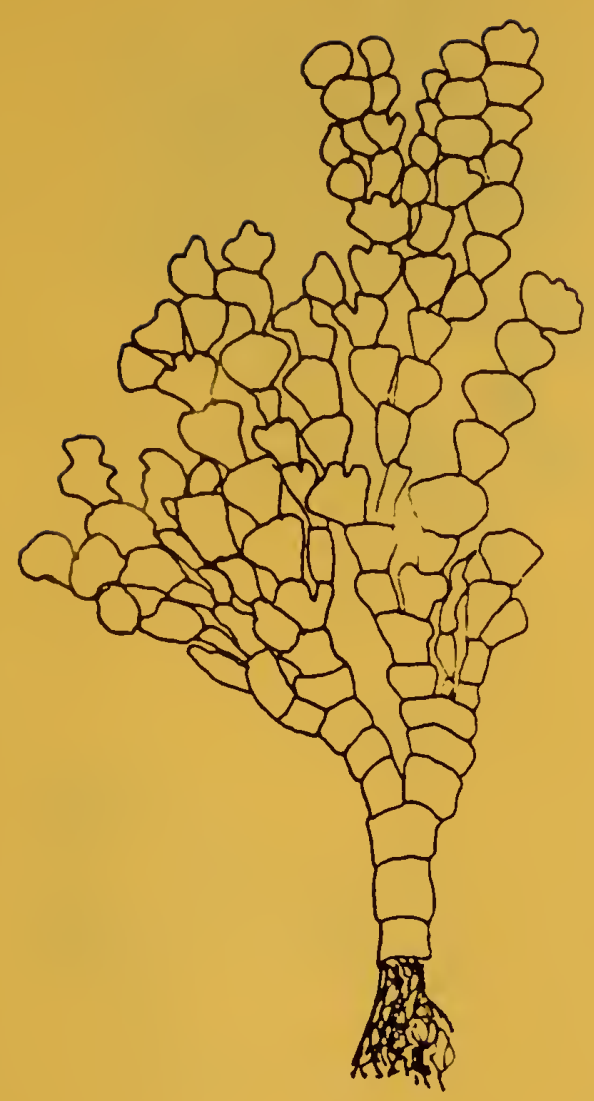

A calcareous algae

Halimeda sp.

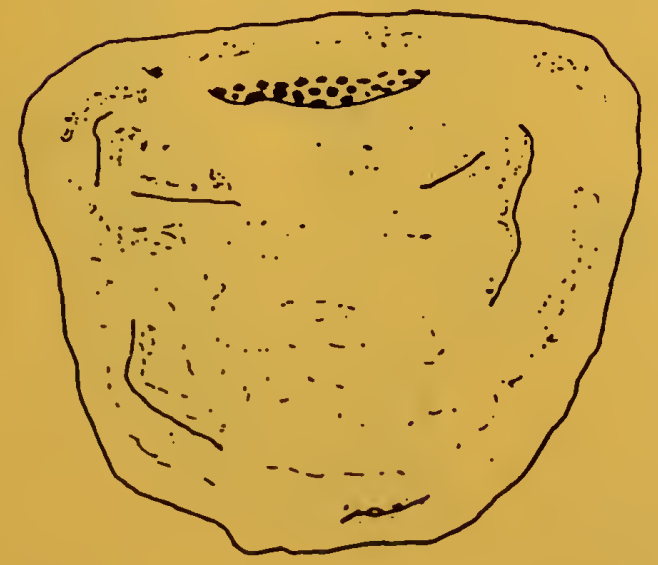

Loggerhead Sponge

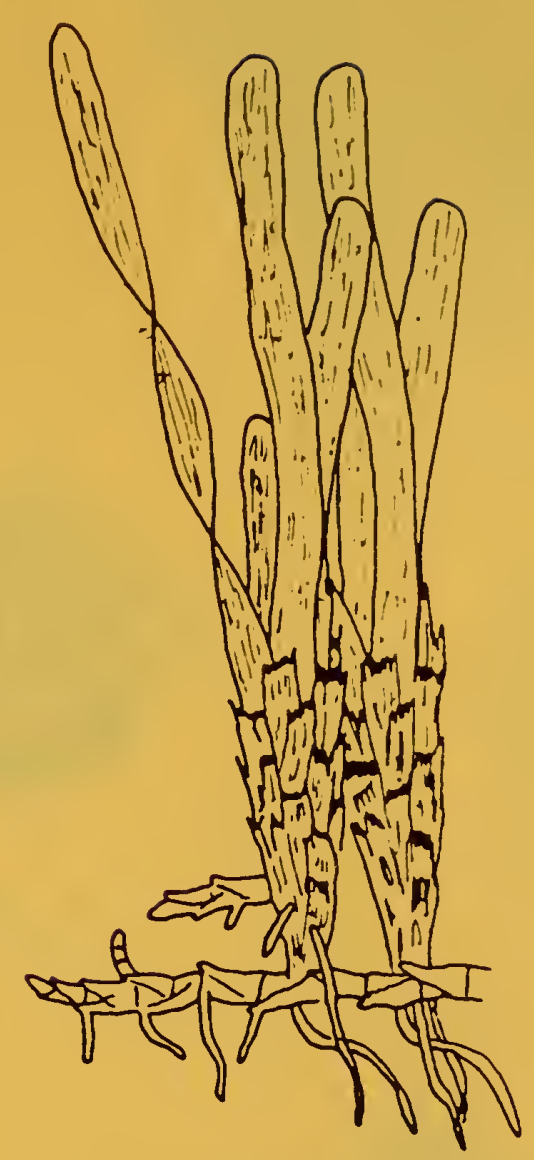

Turtle Grass

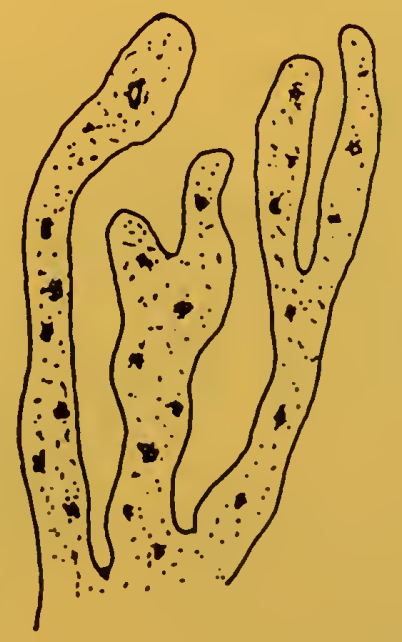

Finger Sponge 
Appendix C. continued:
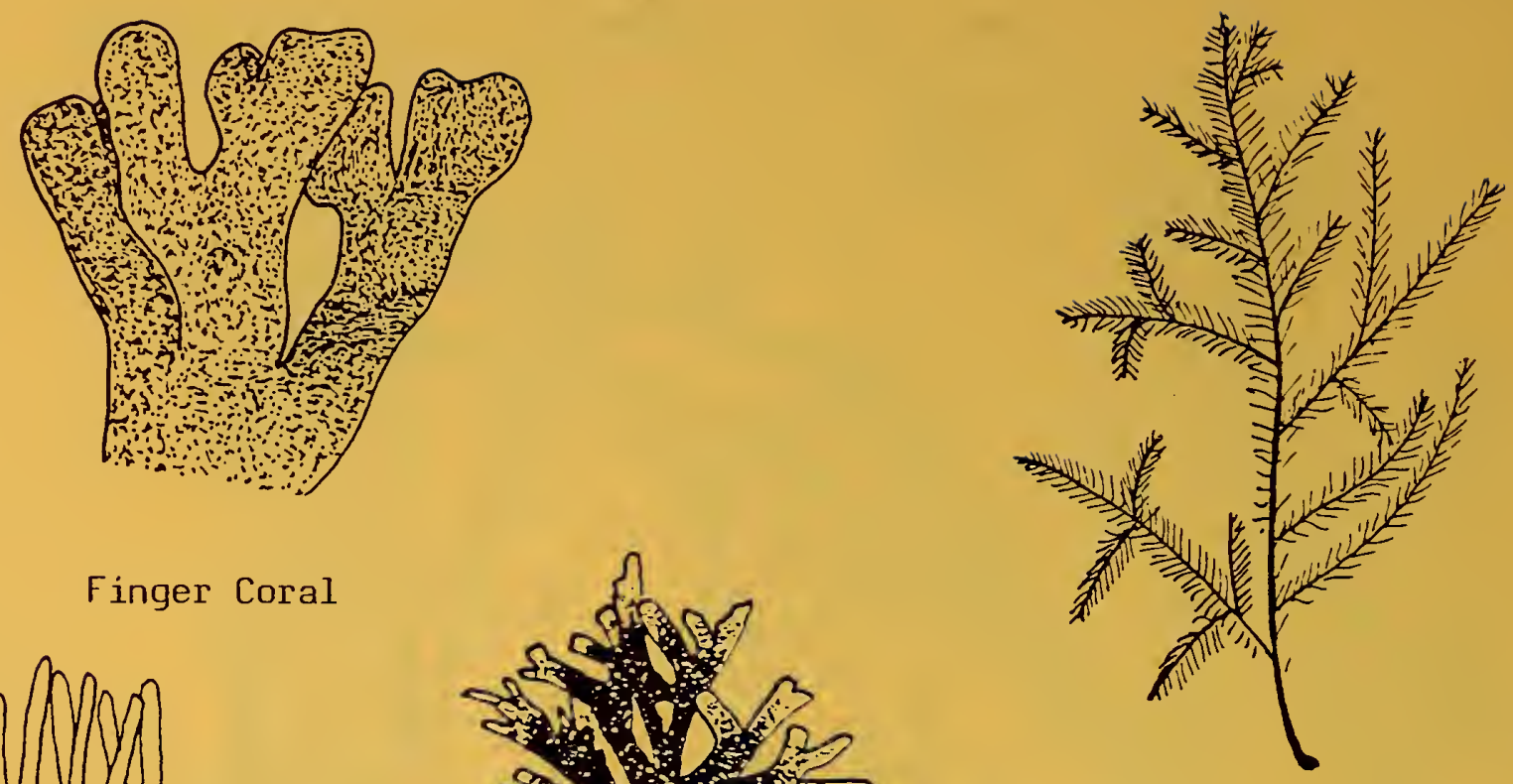

Finger Coral

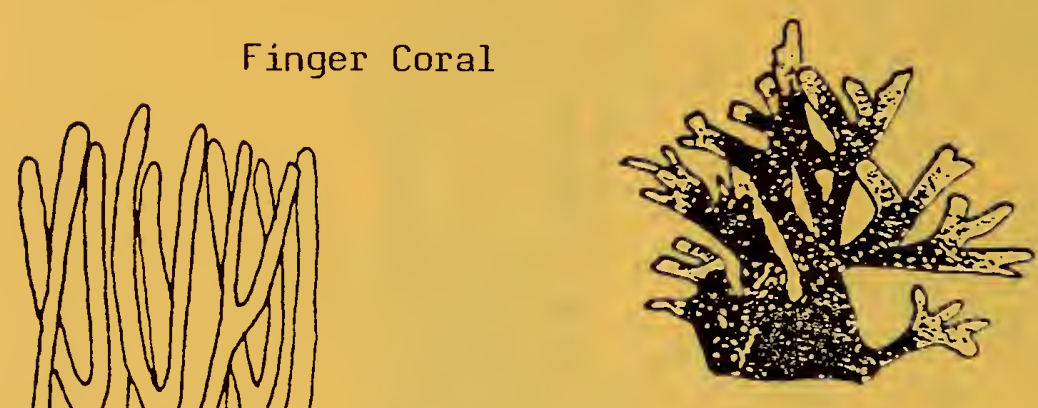

Hydroids

Fire Coral
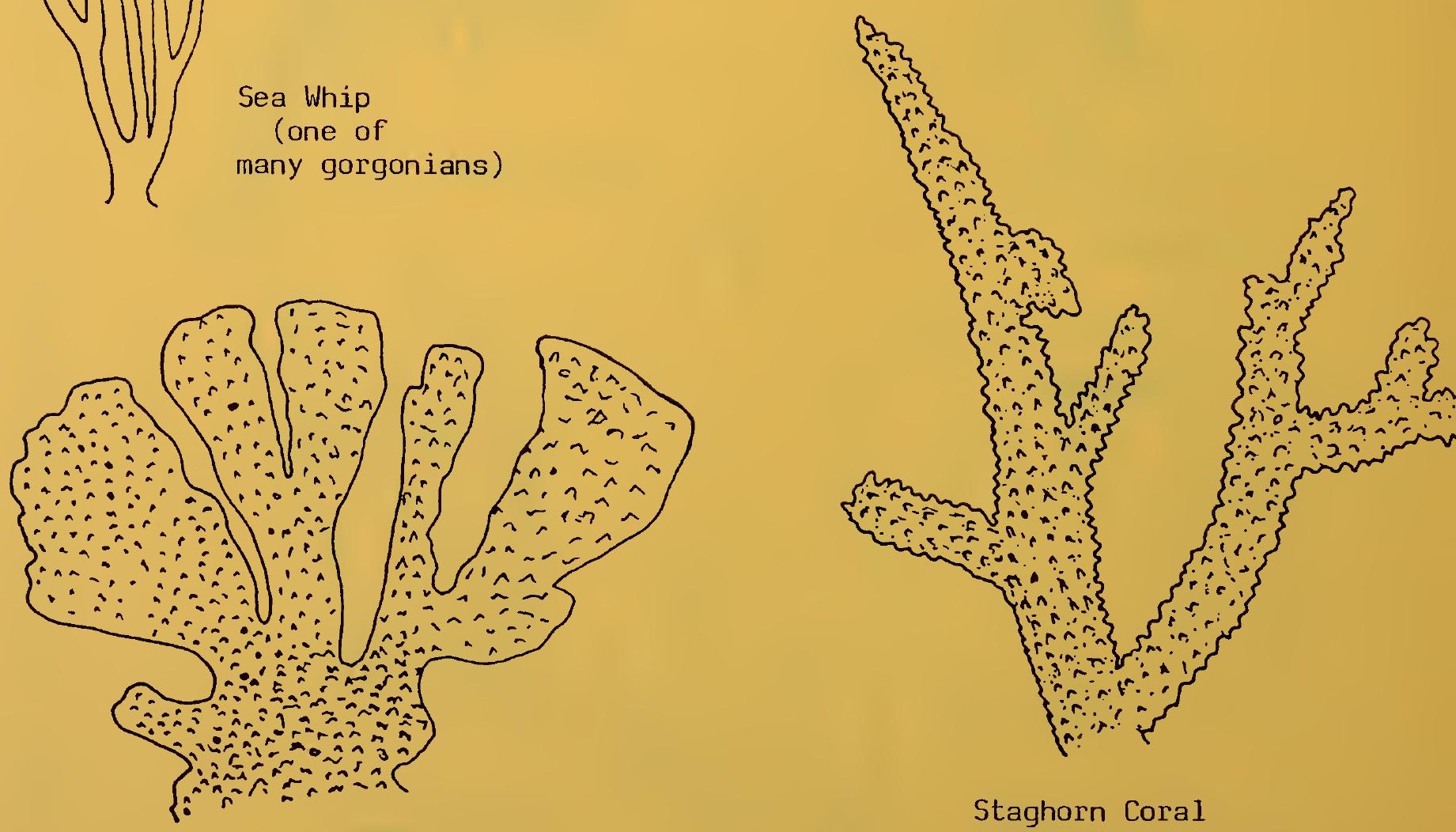

Staghorn Coral

Elkhorn Coral 
Appendix C. continued:
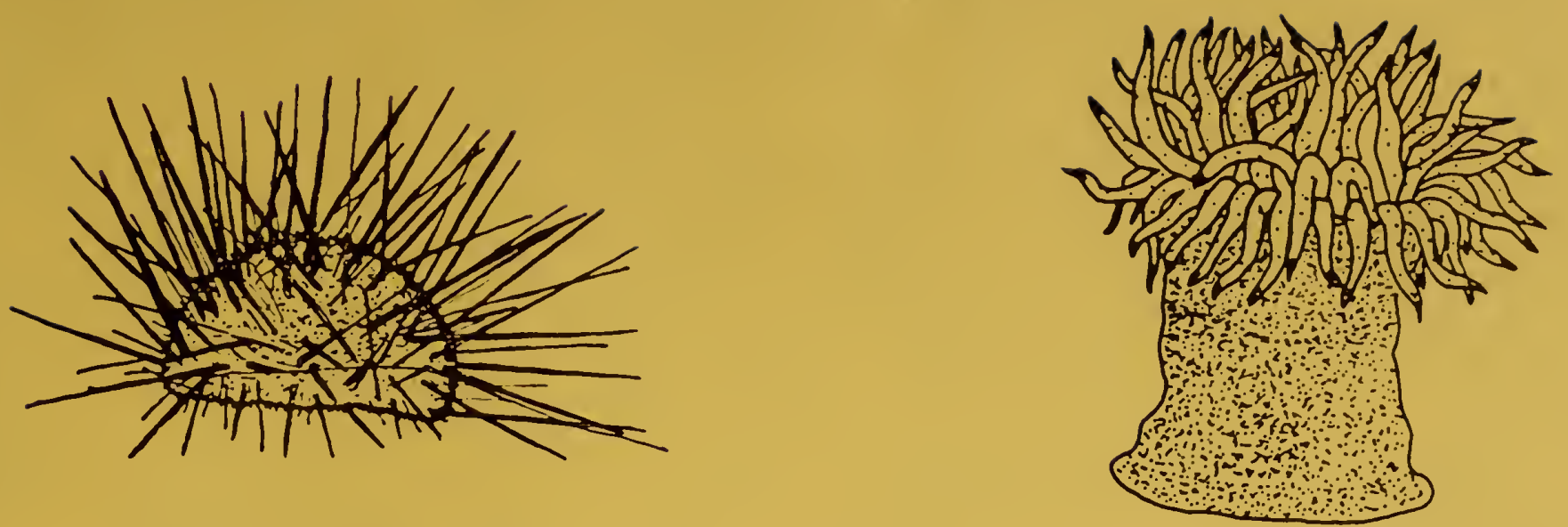

Long-spined Sea Urchin
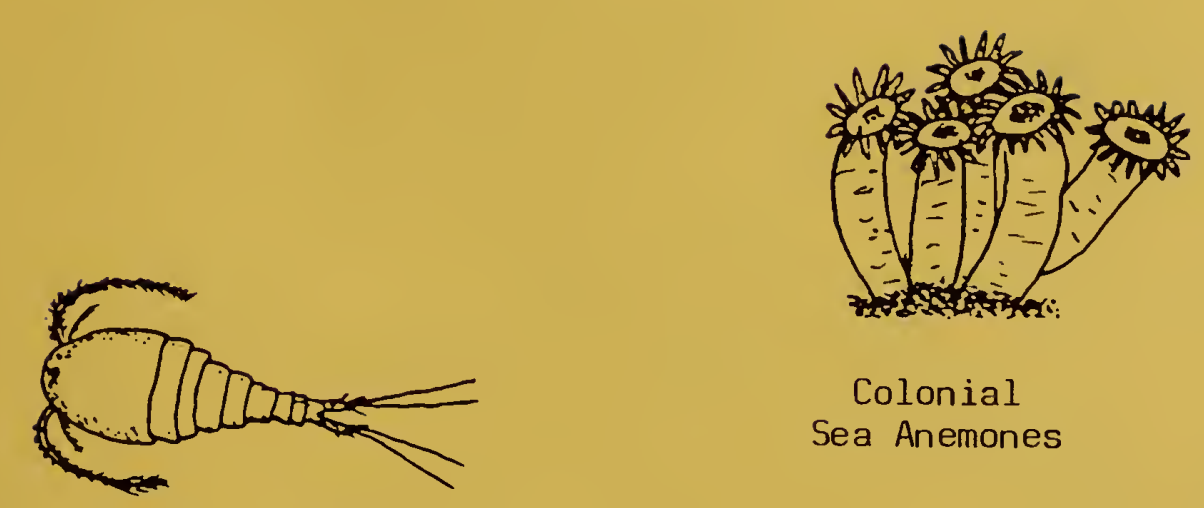

Sea Anemone

\author{
Colonial
}

Sea Anemones

Copepod
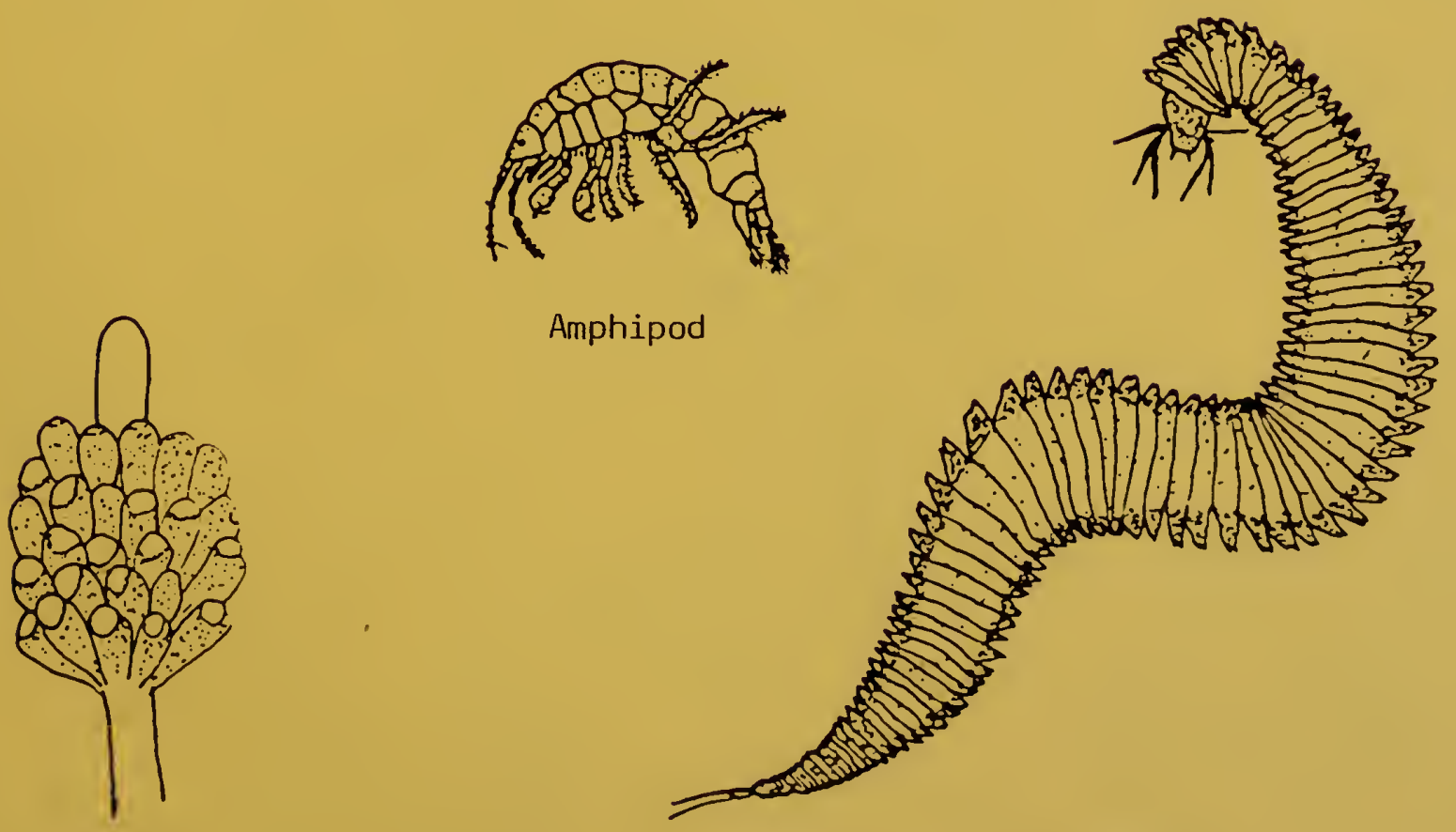

Amphipod

Tunicates (Sea squirts) on a Gorgonian

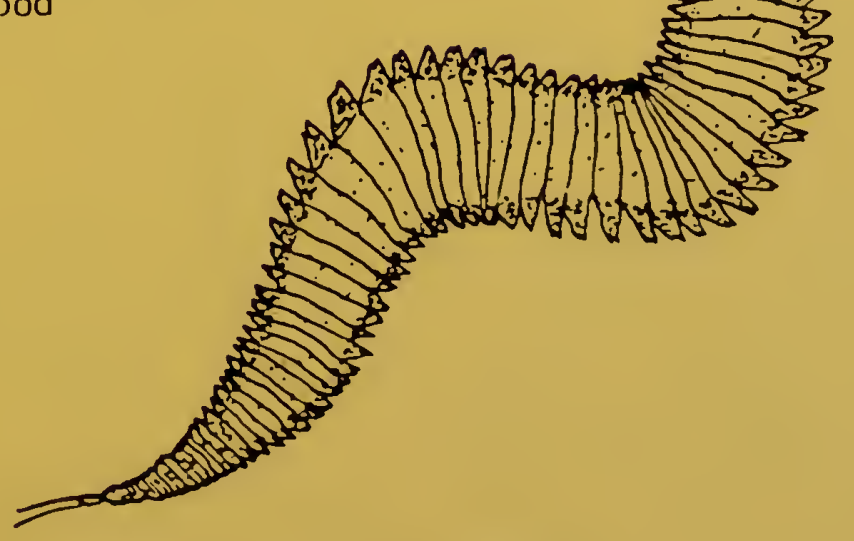

Polychaete Worm 
1 

